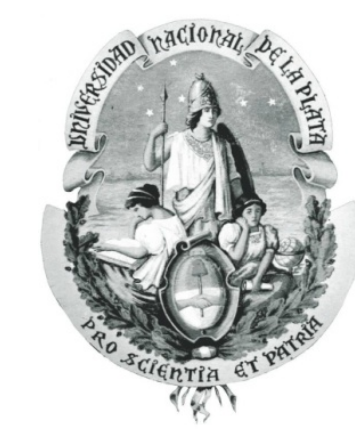

Facultad de Ciencias Naturales y Museo

Universidad Nacional de La Plata

\title{
ESTUDIO DEL MECANISMO DE REGULACIÓN DE LA ESTRUCTURA Y FUNCIÓN DEL RECEPTOR GABA $_{\mathbf{A}}$
}

Tesis doctoral

\author{
Lic. María Celeste Ferreri \\ Instituto de Investigaciones Farmacológicas \\ CONICET-UBA
}

Director: Dra. María Clara Gravielle

Co-director: Dra. Susana Mosca 


\section{AGRADECIMIENTOS}

A la Universidad Nacional de La Plata, por la educación gratuita y de excelencia que permitió mi formación académica y profesional durante todos estos años.

A la Agencia Nacional de Promoción Científica y Tecnológica y al Consejo Nacional de Investigaciones Científicas y Técnicas, por otorgarme las becas doctorales que permitieron que me dedique exclusivamente a mi formación científica.

Al Instituto de Investigaciones Farmacológicas, dirigido por el Dr. Carlos Davio, por permitirme desarrollar el trabajo de investigación en sus instalaciones.

A mi Co-directora, la Dra. Susana Mosca, por aceptarme y sobre todo, ocuparse ante cualquier duda o consulta que le presentara.

A María Clara, principalmente por jugarse por una becaria mayor, con un hijo y sin experiencia. Porque más allá de las pequeñas o grandes diferencias siempre me ayudó, enseñó, comprendió, acompañó y facilitó los medios para realizar mi tesis.

A todos los compañeros del ININFA, por hacer que los días de trabajo sean tan llevaderos, por el compañerismo y por poder contar con todos cada vez que necesité una mano.

A los investigadores, por enriquecer mi formación: Silvia Wikinski, Stella Celuch, Gabriela Acosta, Irene Taravini, Roxana Peroni, Juan Ferrario, Verónica Bisagno, Carolina Ghanem y Graciela Balerio.

A los becarios, por los buenos momentos compartidos: Mercedes Odeón, Andrés Varani, Valeria Pedrón, Martín Cassanelli, María Laura Gutiérrez, Javier Muñiz, Juan Minoia, Betina González, Gimena Gómez y Sara Sanz-Blasco.

A los técnicos: Marina Galli y Fernanda De Fino, por los puchos compartidos, las orejas prestadas y las risas interminables. A Lidia Caballero por aguantar mis rabietas con las heladeras y freezers.

A Esther María, Miguel y Natalia, por mantener nuestras ratas y material del laboratorio limpio, cuidado y siempre a disposición. 
A Cassa, por ayudarme siempre en forma incondicional con esa indispensable pero insoportable máquina llamada computadora.

A Merce, por tantos mates, cigarrillos, catarsis y risas.

A "La Guto", mi compañera y nuera, por acompañarme, enseñarme, aguantarme y apoyarme siempre más allá de las diferencias.

A mis siete hermanas del alma: Ana, Vane, Mery, Lau, Marie, Maru y Andre por ser parte, durante más de 20 años, tanto de los momentos malos como los de los de diversión y disfrute.

A mis amigos biólogos: Yami, Sabi, Martín, Sil y Mari por tantos momentos hermosos compartidos en la facu.

A mi hermano, por acompañarme y compartir estos años.

A mis viejos, por enseñarme que en la vida hay que esforzarse para llegar a lo que se quiere, que nada es fácil pero que tampoco nada es imposible. Por apoyarme e incentivarme aunque no estuvieran de acuerdo con mis decisiones. A vos Ma que me acompañaste todo este tiempo desde algún lado, que estarías orgullosa de mi logro pero sobre todo te enorgullecerías por la persona que soy.

A mis suegros, por cuidar a mis hijos como si fueran los suyos.

A mi amor, Leo por acompañarme, bancarme, ayudarme, quererme, tranquilizarme y respetar mis decisiones sin objeciones.

A mis hijos, Stefi y Ren, a los cuales amo con el alma, por aguantar ausencias y nervios.

A todos y cada uno de Uds. infinitas gracias!!!! 


\section{ÍNDICE}

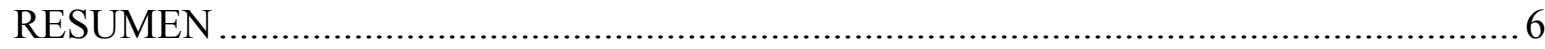

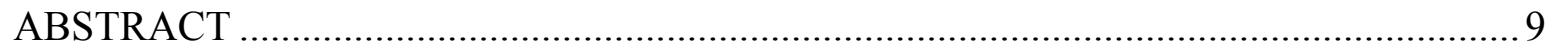

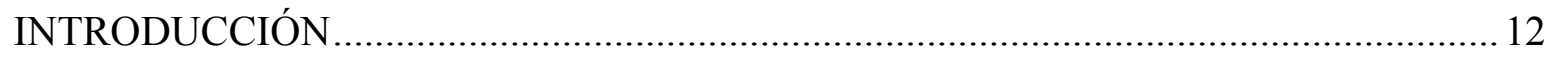

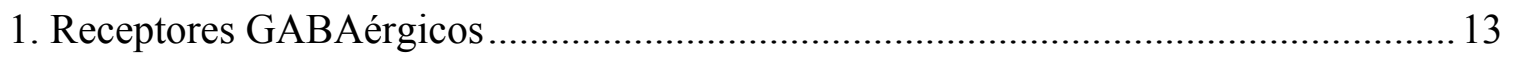

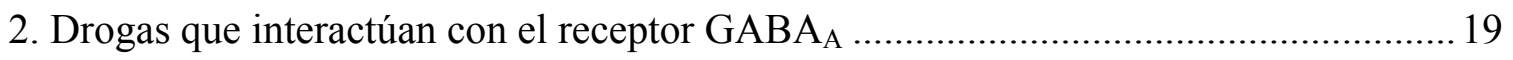

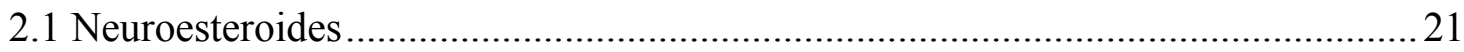

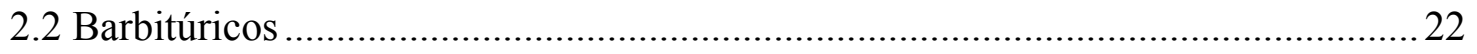

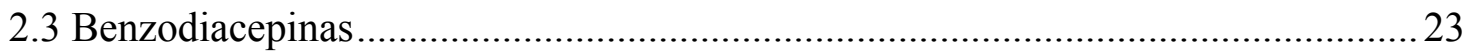

3. Tolerancia a los efectos farmacológicos de las benzodiacepinas ...................................2 27

4. Alteraciones del receptor $\mathrm{GABA}_{\mathrm{A}}$ inducidas por la exposición prolongada a

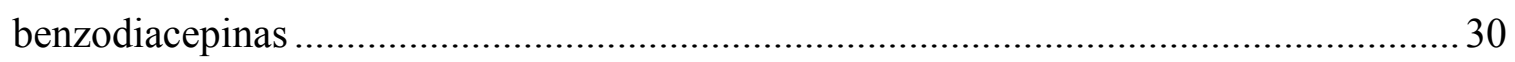

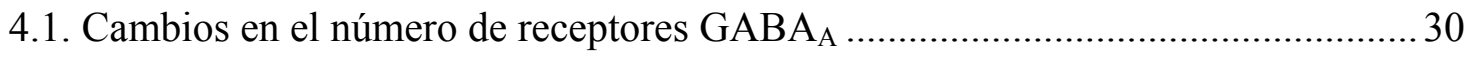

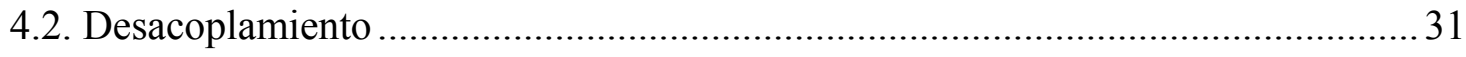

4.3 Cambios en la composición de las subunidades del receptor.....................................33

4.4 Modificaciones post-traduccionales del receptor .....................................................

4.5. Rol de los canales de calcio activados por voltaje ……….......................................36

5. Antecedentes de la línea de investigación ........................................................................ 36

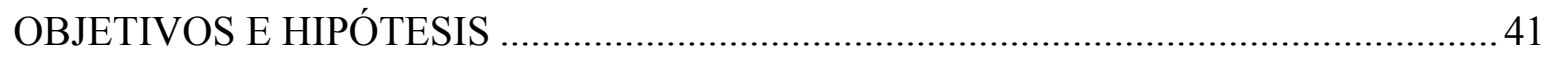

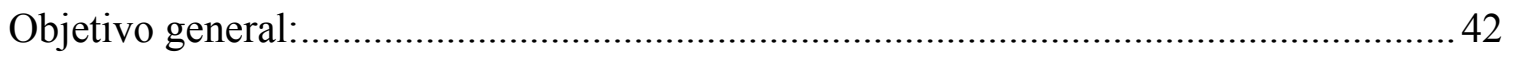

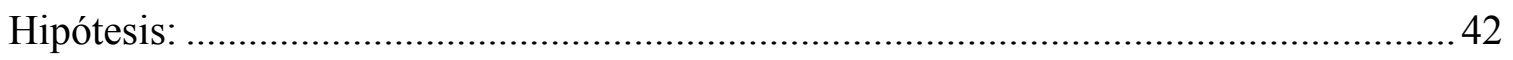

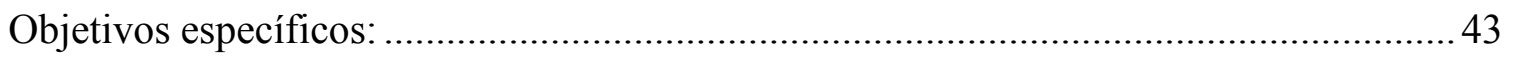

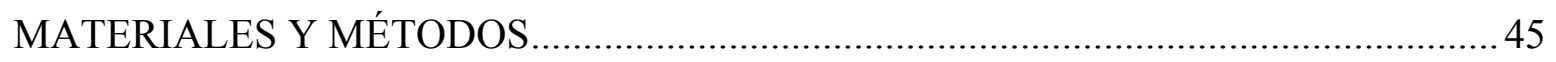

1. Tratamientos crónicos in vivo con diacepam ...............................................................46

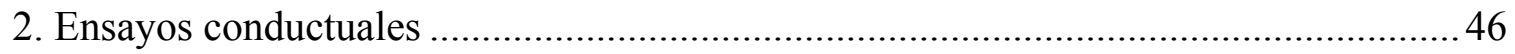

2.1 Medición del efecto ansiolítico de las benzodiacepinas..........................................46 
3. Cuantificación de diacepam en corteza cerebral................................................... 48

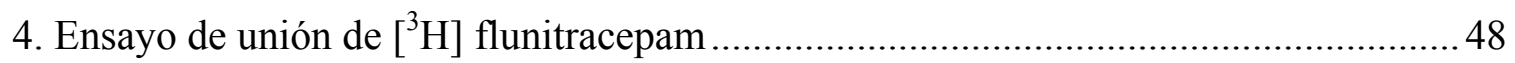

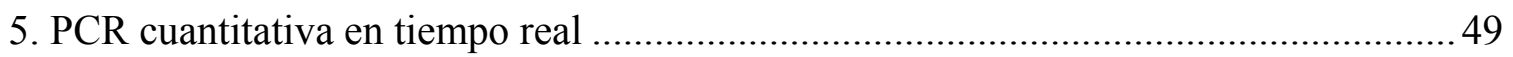

7. Inmunoprecipitación del receptor $\mathrm{GABA}_{\mathrm{A}} \mathrm{y}$ ensayo de western blot ..........................53

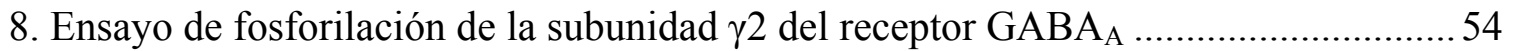

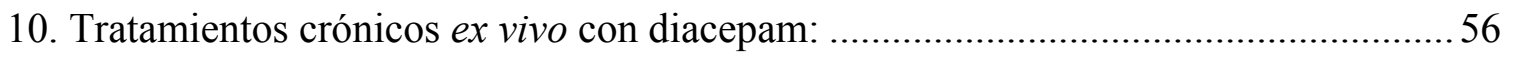

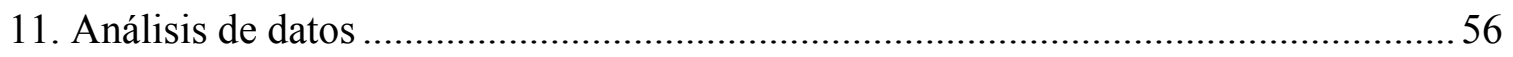

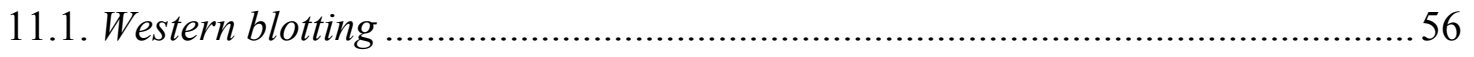

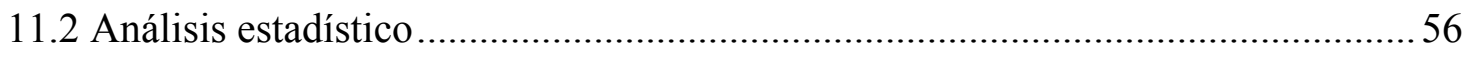

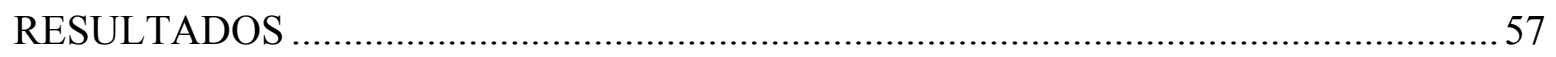

1. Desarrollo de tolerancia a los efectos ansiolíticos y sedativos del diacepam ...............58

2. Concentraciones de diacepam en la corteza cerebral de ratas ................................. 63

3. Efecto de la administración crónica de diacepam sobre la interacción entre los sitios de

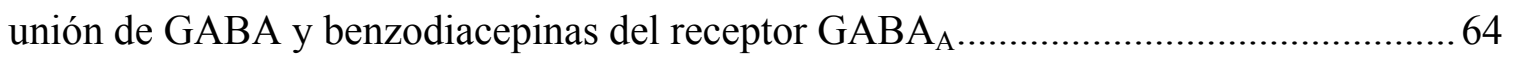

6. Efecto de la administración crónica de diacepam sobre el estado de fosforilación del

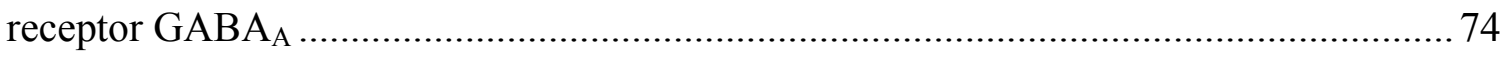

7. Efecto de la exposición crónica a diacepam de neuronas de corteza cerebral en cultivo sobre la interacción entre los sitios de unión de GABA y benzodiacepinas..................... 76

7.1 La exposición crónica de neuronas de corteza cerebral a diacepam induce el desacoplamiento entre los sitios de unión de GABA y benzodiacepinas ..................... 76

7.2 Rol de la activación de CCDV-L sobre el desacoplamiento inducido por la

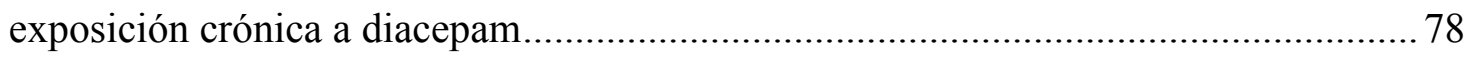

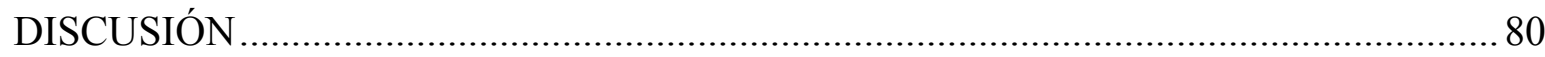

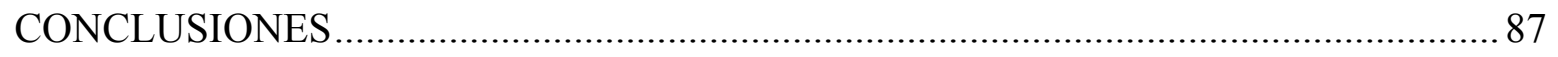

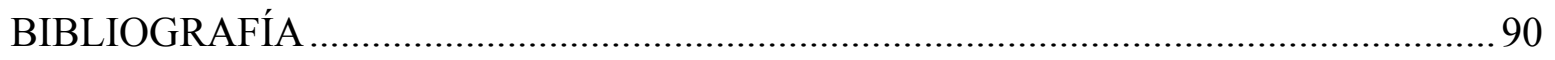




\section{RESUMEN}

Las benzodiacepinas se usan en la clínica como anticonvulsivantes, sedativos/hipnóticos, ansiolíticos y relajantes musculares; también producen amnesia anterógrada y son empleadas para facilitar la anestesia. El efecto terapéutico de las benzodiacepinas está mediado por la unión a un sitio específico en el receptor $\mathrm{GABA}_{\mathrm{A}}$. Dado que en lugar de activar directamente al receptor las benzodiacepinas actúan estimulando las acciones del GABA endógeno, exhiben un gran índice terapéutico y baja toxicidad. Sin embargo, el consumo prolongado de benzodiacepinas induce tolerancia a la mayoría de sus efectos farmacológicos.

El objetivo del presente trabajo fue analizar el mecanismo molecular de tolerancia a las benzodiacepinas, realizando estudios conductuales en combinación con análisis bioquímicos. Se estudió el efecto de administraciones diarias (1 inyección subcutánea por día) con vehículo o diacepam $(15 \mathrm{mg} / \mathrm{kg})$ en ratas durante 1 (tratamiento agudo), 7 o 14 días. Los estudios conductuales se llevaron a cabo 2 horas luego de la última inyección pues es el momento donde se alcanza la máxima concentración de diacepam en el plasma y el cerebro. El efecto ansiolítico de la benzodiacepina se determinó en el test del laberinto en cruz elevado, estimándolo como un aumento en el número de entradas y en el tiempo de permanencia en los brazos abiertos en relación al grupo de ratas administradas con vehículo. El efecto ansiolítico persistió luego del tratamiento con diacepam por 7 días pero fue abolido luego de la administración de 14 días. De este modo, la tolerancia a los efectos ansiolíticos del diacepam se detectó solamente luego del tratamiento más prolongado. El efecto sedativo del diacepam, estimado como una reducción en la actividad locomotora en el test del campo abierto comparado con animales tratados con vehículo, se observó luego del tratamiento agudo pero no se detectó luego de los tratamientos crónicos de 7 o 14 días. Por consiguiente, la tolerancia a los efectos sedativos se detectó luego de los dos tratamientos crónicos con diacepam. Estos resultados están de acuerdo con las evidencias previas que indican que la tolerancia a las benzodiacepinas se desarrolla con diferentes cursos temporales dependiendo del efecto farmacológico.

Nuestros resultados mostraron que la concentración de diacepam en la corteza cerebral de las ratas no disminuyó luego de los dos tratamientos crónicos con la 
benzodiacepina con respecto al grupo de animales que recibió el tratamiento agudo, indicando que el proceso de tolerancia no está mediado por cambios en factores farmacocinéticos.

Diversos estudios indican que la administración crónica con benzodiacepinas produce una reducción en la interacción entre los sitios de unión de GABA y benzodiacepinas, llamada desacoplamiento. A fin de investigar si la tolerancia a los efectos sedativos y/o ansiolíticos del diacepam inducida por nuestros protocolos de tratamiento está acompañada por el desarrollo de desacoplamiento, medimos la potenciación de la unión de flunitrazepam por GABA en homogenatos de membrana de la corteza cerebral de ratas tratadas con diacepam. Los dos tratamientos crónicos con diacepam de 7 y 14 días indujeron un desacoplamiento significativo, en cambio, el tratamiento agudo con diacepam no modificó el grado de acoplamiento entre los sitios de unión de GABA y benzodiacepinas, indicando que el desacoplamiento es el resultado de un tratamiento crónico con benzodiacepinas. Estos resultados sugieren que la tolerancia a los efectos sedativos del diacepam está asociada al desacoplamiento. Dado que la ocurrencia de desacoplamiento precedió al desarrollo de tolerancia a los efectos ansiolíticos del diacepam, el mecanismo de tolerancia a este efecto farmacológico estaría mediado por un mecanismo diferente.

Teniendo en cuenta que la acción de las benzodiacepinas está influenciada por el subtipo de subunidad $\alpha$ del receptor $\mathrm{GABA}_{\mathrm{A}}$, es posible que el mecanismo de tolerancia involucre una alteración en la composición de subunidades del receptor. Con el objeto de investigar dicha hipótesis, estudiamos el efecto de los tratamientos crónicos con diacepam sobre la expresión de las subunidades $\alpha$ del receptor sensibles a benzodiacepinas. Experimentos de PCR cuantitativa en tiempo real indicaron que el tratamiento crónico de 14 días con diacepam pero no el de 7 días produjo un aumento en los niveles de ARN mensajero de la subunidad $\alpha 1$ del receptor $\mathrm{GABA}_{\mathrm{A}}$. Este incremento se correlacionó con un aumento en los niveles del péptido $\alpha 1$ medido mediante ensayos de western blot. Ensayos de inmunoprecipitación del receptor $\mathrm{GABA}_{\mathrm{A}}$ seguidos por análisis de western blot demostraron que este aumento en los niveles de la subunidad $\alpha 1$ del receptor resulta en un incremento en el porcentaje de receptores conteniendo dicha subunidad. Por lo tanto, el 
desarrollo de tolerancia a los efectos ansiolíticos del diacepam estaría acompañado por un cambio en la combinación de subunidades del receptor $\mathrm{GABA}_{\mathrm{A}}$.

En estudios previos demostramos que el desacoplamiento inducido por la exposición continua de neuronas de corteza cerebral de rata a GABA está acompañado por un aumento en la fosforilación de la subunidad $\gamma 2$ del receptor $\mathrm{GABA}_{\mathrm{A}}$ en residuos serina. En este trabajo investigamos si el desacoplamiento producido por los tratamientos crónicos con diacepam está acompañado por cambios en el estado de fosforilación del receptor $\mathrm{GABA}_{\mathrm{A}}$. Mediante ensayos de western blot demostramos que los dos tratamientos crónicos de 7 y 14 días con diacepam resultaron en un aumento en el grado de fosforilación de la subunidad $\gamma 2$ del receptor $\mathrm{GABA}_{\mathrm{A}}$ en el residuo serina 327. Por consiguiente, estos resultados sugieren que la tolerancia a los efectos sedativos del diacepam estaría mediada por un proceso de desacoplamiento que sería el resultado de un aumento en el grado de fosforilación del receptor $\mathrm{GABA}_{\mathrm{A}}$.

Resultados a partir de experimentos ex vivo en cultivos primarios neuronales de corteza cerebral de rata demostraron que la exposición crónica (48 horas) a diacepam indujeron desacoplamiento, sugiriendo que estos cultivos representan un buen modelo para estudiar las bases moleculares de la tolerancia. El desacoplamiento fue inhibido en presencia de flumacenil, demostrando que este proceso está mediado por la unión del diacepam a su sitio de unión específico. Además, el desarrollo de desacoplamiento requiere la activación del canal de cloruro del receptor $\mathrm{GABA}_{\mathrm{A}} \mathrm{y}$ depende de la activación de canales de calcio dependientes de voltaje de tipo L. El flujo de calcio a través de dichos canales podría activar la proteína quinasa $\mathrm{C}$ que a su vez mediaría la fosforilación de la subunidad $\gamma 2$ del receptor $\mathrm{GABA}_{\mathrm{A}}$. 


\section{ABSTRACT}

Benzodiazepines are used in the clinic as anticonvulsants, sedative/hypnotic, anxiolytic and muscle relaxant; they also produce anterograde amnesia and are used to facilitate anesthesia. The therapeutic effect of benzodiazepines is mediated by specific binding to the $\mathrm{GABA}_{\mathrm{A}}$ receptor. Because benzodiazepines stimulate GABA actions instead of directly activate the $\mathrm{GABA}_{\mathrm{A}}$ receptor, they exhibit a high therapeutic index and low toxicity. However, the prolonged consumption of benzodiazepines induces tolerance to most of their pharmacological effects.

The aim of the present work was to analyze the molecular mechanism of tolerance to benzodiazepines, by performing behavioral studies in combination with biochemical analyses. We studied the effect of daily administrations (1 subcutaneous injection per day) with vehicle or diazepam $(15 \mathrm{mg} / \mathrm{kg})$ to rats for 1 (acute treatment), 7 or 14 days. The behavioral studies were carried out $2 \mathrm{~h}$ after the last injection, at the time of peak concentration of diazepam in the plasma and brain. The anxiolytic effect of the benzodiazepine was determined in the elevated plus-maze by estimating the increase in the number of entries onto and the time spent on the open arms relative to the control group treated with vehicle. The anxiolytic effect persisted after the 7-day treatment with diazepam but was abolished after the 14-day administration. Thus, the tolerance to the anxiolytic effects of diazepam was only detected after the longer treatment. The sedative effect of diazepam, estimated as a reduction in the locomotor activity in an open field compared to animals administered with vehicle, was observed after the acute treatment but was undetectable after the 7-and 14-days treatments. Therefore, the tolerance to the sedative effects was detected after both chronic treatments. These results are in agreement with previous evidences that indicate that tolerance to benzodiazepines develops at different rates depending on the pharmacological effect.

Our results showed that the diazepam concentration in the rat cerebral cortex did not decline after the chronic treatments with the benzodiazepine relative to the group of animals that received an acute treatment, indicating that the process of tolerance is not mediated by changes in pharmacokinetic factors. 
Different studies indicate that the chronic administration with benzodiazepines produces a reduction in the interaction between GABA and benzodiazepine binding sites, named uncoupling. To investigate whether the tolerance to the sedative and/or anxiolytic effects of diazepam induced by our treatment protocols is accompanied by the development of uncoupling, we measured the potentiation of flunitrazepam binding by GABA in membrane homogenates from the cerebral cortices of rats treated with diazepam. The two chronic treatments with diazepam for 7 and 14 days induced a significant uncoupling, whereas the acute treatment did not modify the degree of coupling between the GABA and benzodiazepine sites. These results suggest that the tolerance to the sedative effects of diazepam is associated with the uncoupling. Since the occurrence of uncoupling preceded the development of tolerance to the anxiolytic effects of diazepam, the mechanism of tolerance to this pharmacological effect could be mediated by a different mechanism.

Because the action of benzodiazepines is influenced by the subtype of $\mathrm{GABA}_{\mathrm{A}}$ receptor $\alpha$ subunit, it is possible that the mechanism of tolerance involves an alteration in the subunit composition of the receptor. To investigate this hypothesis, we studied the effect of the chronic treatments with diazepam on the expression of benzodiazepinesensitive $\mathrm{GABA}_{\mathrm{A}}$ receptor $\alpha$ subunits. Quantitative real-time PCR experiments indicated that the chronic treatment with diazepam for 14 days but not 7 days produced an increase in the mRNA levels of the $\alpha 1 \mathrm{GABA}_{\mathrm{A}}$ receptor subunit. This increment was correlated with an increase in the al peptide levels measured by western blotting. Receptor immunoprecipitation assays followed by western blot experiments demonstrated that this increment in the $\alpha 1$ subunit levels results in an increase in the percentage of receptors containing this subunit. Thus, the development of tolerance to the anxiolytic effects of diazepam is accompanied by a change in the subunit combination of the $\mathrm{GABA}_{\mathrm{A}}$ receptor.

In previous studies we demonstrated that the uncoupling induced by the continuous exposure of rat cerebral cortical neurons to GABA is accompanied by an increase in the phospshorylation of the $\mathrm{GABA}_{\mathrm{A}}$ receptor $\gamma 2$ subunit at serine residues. In this work we investigated whether the uncoupling induced by the chronic treatments with diazepam is accompanied by changes in the phosphorylation state of the $\mathrm{GABA}_{\mathrm{A}}$ receptor. We demonstrated by means of western blot assays that both chronic treatments with diazepam 
resulted in an increase in the degree of phsophorylation of $\mathrm{GABA}_{\mathrm{A}}$ receptor $\gamma 2$ subunit at serine 327. Therefore, these results suggest that tolerance to the sedative effects of diazepam is mediated by an uncoupling process that could be the result of an increase in the phosphorylation degree of the $\mathrm{GABA}_{\mathrm{A}}$ receptor.

Results from ex vivo experiments performed in primary neuronal cultures from rat cerebral cortices demonstrated that the chronic exposure $(48 \mathrm{~h})$ to diazepam induced uncoupling, suggesting that these cultures represent a good model to study the molecular bases of tolerance. The uncoupling was inhibited in the presence of flumazenil, demonstrating that this process is mediated by binding of diazepam to its specific site. Besides, the development of uncoupling requires the activation of the $\mathrm{GABA}_{\mathrm{A}}$ receptor chloride channel and depends on the activation of L-type voltage gated calcium channels. The calcium influx through these channels may activate the protein kinase $C$ that could mediate the phosphorylation of the $\mathrm{GABA}_{\mathrm{A}}$ receptor $\gamma 2$ subunit. 
INTRODUCCIÓN 


\section{Receptores GABAérgicos}

El ácido $\gamma$ aminobutírico (GABA) es el transmisor inhibitorio primario en el sistema nervioso central adulto y puede activar tres clases de receptores: receptores ionotrópicos tipo $\mathrm{A}\left(\mathrm{GABA}_{\mathrm{A}}\right)$ y tipo $\mathrm{C}\left(\mathrm{GABA}_{\mathrm{C}}\right)$ y receptores metabotrópicos tipo $\mathrm{B}\left(\mathrm{GABA}_{\mathrm{B}}\right)$. Los receptores ionotrópicos pertenecen a la superfamilia de canales iónicos activados por ligando que incluye a los receptores de acetilcolina nicotínicos, de glicina y de serotonina 5-HT3 (Unwin 1989); este tipo de receptores median las acciones rápidas del GABA en el cerebro (receptores $\mathrm{GABA}_{\mathrm{A}}$ ), y en la retina (receptores $\mathrm{GABA}_{\mathrm{C}}$ ). Los receptores $\mathrm{GABA}_{\mathrm{B}}$ metabotrópicos pertenecen a la familia de receptores acoplados a proteína $\mathrm{G}$ y median las acciones lentas y prolongadas del GABA en el cerebro (Mehta and Ticku 1999; Bormann 2000).

Los receptores de la familia de canales iónicos activados por ligando son heteropentámericos y están formados por subunidades homólogas que comparten la siguiente estructura común (Fig. 1): un largo dominio amino terminal extracelular y cuatro dominios transmembrana (TM), con un largo dominio intracelular entre TM3 y TM4. Los dominios TM2 de todas las subunidades forman el poro del canal (Jacob, Moss et al. 2008). Los receptores $\mathrm{GABA}_{\mathrm{A}}$ son canales iónicos permeables a los iones cloruro $\left(\mathrm{Cl}^{-}\right)$ principalmente. La unión de un agonista al receptor induce la apertura del canal permitiendo el flujo de estos iones de acuerdo a sus gradientes electroquímicos. La corriente mediada por $\mathrm{Cl}^{-}$puede ser despolarizante o hiperpolarizante dependiendo de la actividad de los cotransportadores NKCCI (transporta iones $\mathrm{Cl}^{-}$hacia el interior celular) y $\mathrm{KCC} 2$ (transporta iones $\mathrm{Cl}^{-}$hacia el exterior celular). En el sistema nervioso inmaduro las concentraciones intracelulares de $\mathrm{Cl}^{-}$son elevadas debidas a la actividad de NKCCI y por lo tanto las acciones del GABA son despolarizantes. En el sistema nervioso maduro la activación del receptor $\mathrm{GABA}_{\mathrm{A}}$ induce principalmente el influjo de $\mathrm{Cl}^{-}$debido a la actividad de KCC2 que se expresa más tarde durante el desarrollo, mientras que la actividad de NKCCI es reducida (Fig. 2) (Rivera, Voipio et al. 2005). En esta última situación se produce una disminución en la probabilidad de generación de un potencial de acción debido a la hiperpolarización y a un aumento en la conductancia (shunting inhibition). Sin embargo, el receptor $\mathrm{GABA}_{\mathrm{A}}$ puede mediar también respuestas despolarizantes en el adulto 
en ciertas condiciones fisiológicas y patológicas donde ocurre una activación intensa del receptor (Sun, Zhao et al. 2001; Timofeev, Grenier et al. 2002).

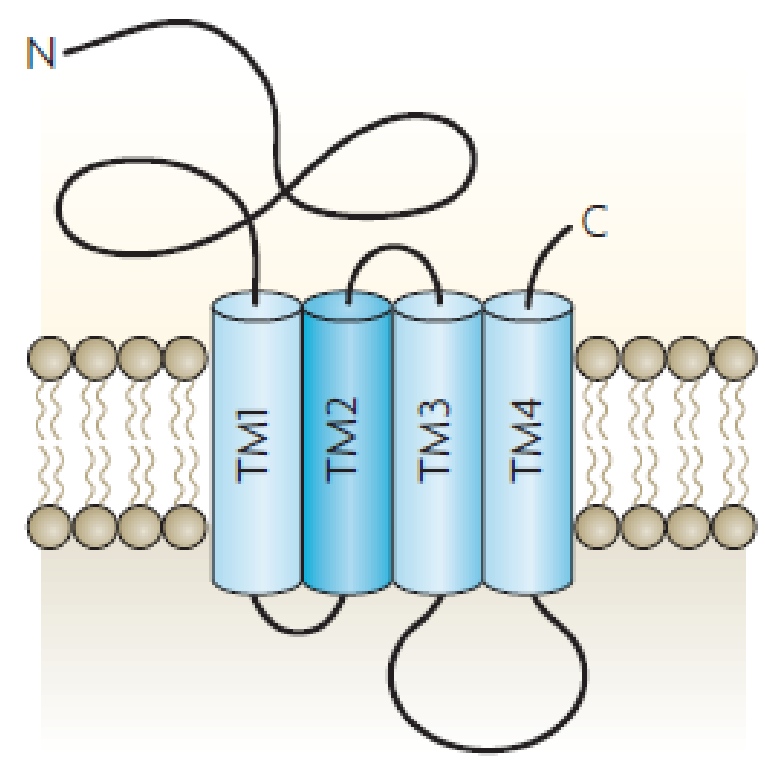

Figura 1: Estructura las subunidades del receptor $\mathbf{G A B A _ { A }}$. Las subunidades del receptor GABA $_{A}$ poseen cuatro pasos de transmembrana (TM1-4). El dominio TM2 de cada subunidad forma el poro del canal. El dominio intracelular ubicado entre TM3 y TM4 interacciona con proteínas que modulan la actividad de receptor. 
A

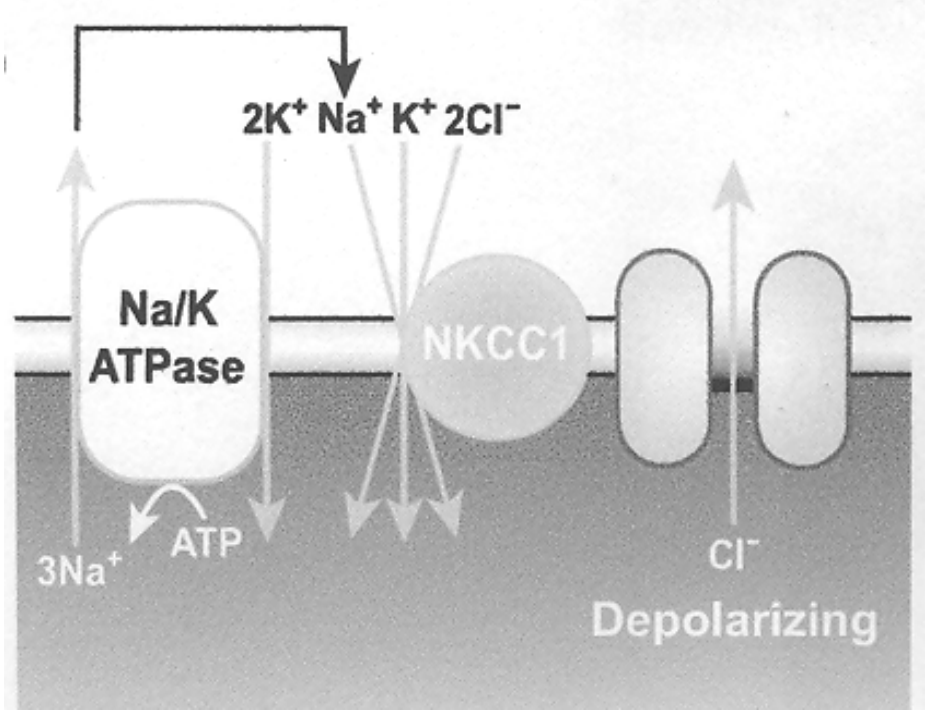

B

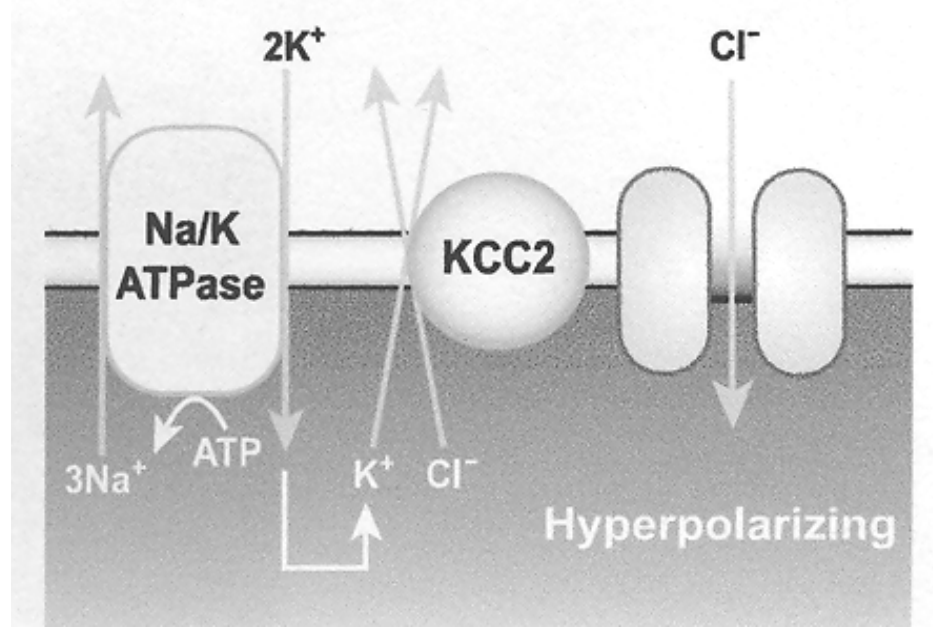

Figura 2: A Acción despolarizante del GABA en el sistema nervioso inmaduro; B Acción hiperpolarizante del GABA en el sistema nervioso maduro.

Los receptores $\mathrm{GABA}_{\mathrm{A}}$ están formados por subunidades codificadas por 18 genes, dichas subunidades pueden ser divididas en siete clases de acuerdo a sus homologías de 
secuencia: $\alpha 1-6, \beta 1-3, \gamma 1-3, \delta, \varepsilon(1-3), \theta, \pi$, (Fig. 3). La diversidad estructural del receptor $\mathrm{GABA}_{\mathrm{A}}$ se ve incrementada por el splicing alternativo de algunos de los genes de las subunidades que conforman el receptor. Sin embargo, la mayoría de los receptores $\mathrm{GABA}_{\mathrm{A}}$ están compuestos por dos subunidades $\alpha$, dos subunidades $\beta$ y una subunidad $\gamma$. Las subunidades $\delta, \varepsilon$ y $\pi$ pueden reemplazar a la subunidad $\gamma$, mientras que la subunidad $\theta$ puede reemplazar a la subunidad $\beta$. Si bien la cantidad de combinaciones de subunidades posibles para la formación de los receptores $\mathrm{GABA}_{\mathrm{A}}$ es enorme, existe un número limitado de subtipos de receptores que se expresan en las diferentes regiones del cerebro, siendo el más abundante el conformado por las subunidades $\alpha 1 \beta 2 \gamma 2$ (Fig. 4) (Whiting 2003).

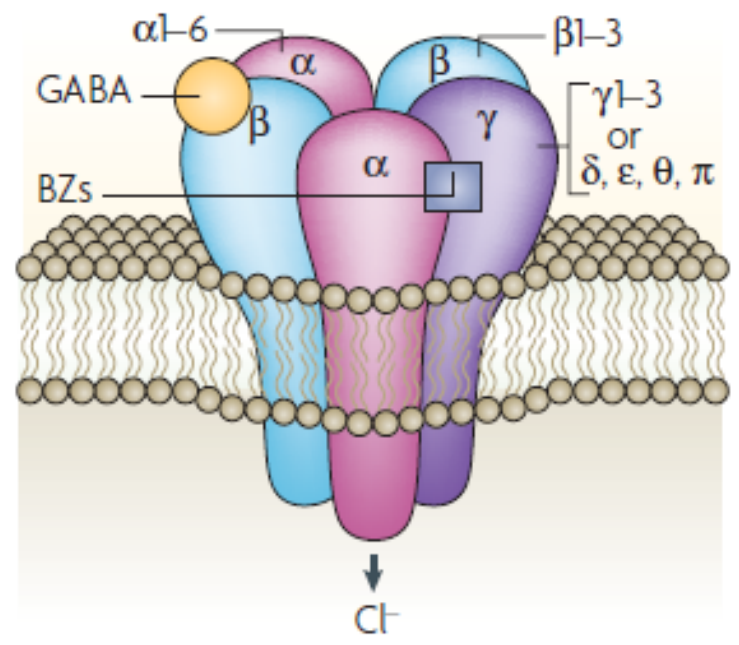

Figura 3: Estructura del receptor $\mathbf{G A B A}_{\mathbf{A}}$. Cinco subunidades pertenecientes a distintas subfamilias se ensamblan para formar el canal heteropentamérico permeable a $\mathrm{Cl}^{-}$. La unión a GABA se produce en la interfase entre las subunidades $\alpha$ y $\beta$. La unión a benzodiacepinas se produce en la interfase entre las subunidades $\alpha(1,2,3$ o 5) y las subunidades $\gamma$. 


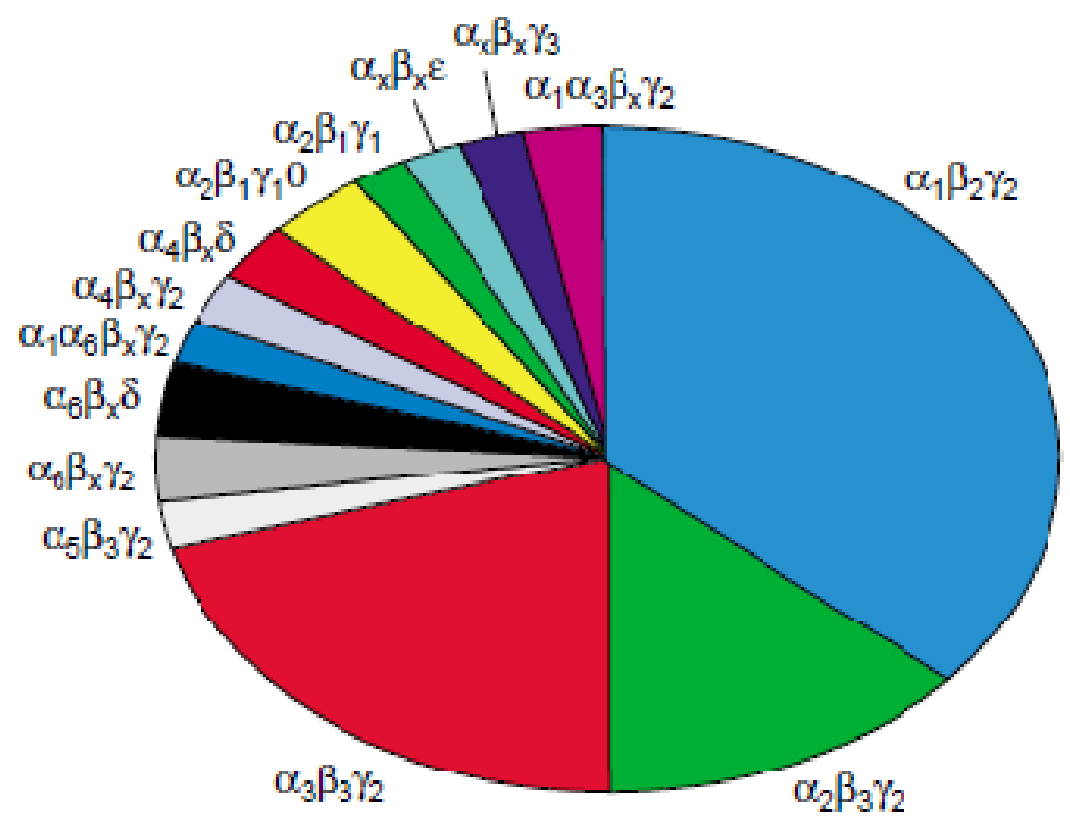

Figura 4: Representación aproximada de la abundancia de los subtipos de receptores $\mathrm{GABA}_{\mathrm{A}}$ en cerebro de rata. El subíndice $\mathrm{x}$ indica que el subtipo de subunidad no es conocido. (Whiting 2003)

Las distintas subunidades presentan una distribución diferente en el sistema nervioso central (Uusi-Oukari and Korpi 2010). Estudios inmunohistoquímicos y de hibridización in situ demuestran que las subunidades $\alpha 1, \beta 1-3$ y $\gamma 2$ presentan un patrón de expresión amplio, mientras que el resto de las subunidades están localizadas en áreas restringidas del cerebro. Las subunidades $\alpha 1, \beta 2$ y $\gamma 2$ exhiben el mayor grado de co-localización apoyando las evidencias que indican que esta combinación de subunidades representa al subtipo de receptor más abundante en el cerebro. La subunidad $\alpha 1$ está presente en casi todas las áreas del cerebro y es considerada la subunidad $\alpha$ más ubicua. Se encuentran niveles bajos de expresión de $\alpha 1$ en el estriado, núcleo talámico reticular y la capa granular interna del bulbo olfatorio. La subunidad $\alpha 2$ es más abundante en el bulbo olfatorio accesorio, capa molecular del giro dentado y CA3 del hipocampo, núcleo amigdaloide, septum, estriado, accumbens e hipotálamo. En contraste, la subunidad $\alpha 3$ es predominante en el bulbo olfatorio principal (capas moleculares y plexiforme externa). La subunidad $\alpha 4$ se expresa en 
el tálamo, estriado, núcleo accumbens, tubérculo olfatorio y giro dentado (capa molecular). La expresión de la subunidad $\alpha 5$ es alta en el bulbo olfatorio, capas internas de la corteza cerebral, núcleo endopiriforme, subculículo, cuerno de Amón y núcleo hipotalámico ventromedial. La subunidad $\alpha 6$ exhibe la localización más restringida y solo se encuentra en las células granulares del cerebelo y el núcleo coclear. La subunidad $\beta 2$ es la más abundante de las tres subunidades $\beta$ en el cerebro. Las tres subunidades $\beta$ se expresan ampliamente en el cerebro, especialmente en la corteza cerebral. La subunidad $\gamma 2$ es la subunidad $\gamma$ más ampliamente distribuida y tiene altos niveles de expresión en el bulbo olfatorio, corteza cerebral, hipocampo, amígdala, septum, núcleos de la base e hipotálamo. Los mayores niveles de expresión de la subunidad $\gamma 1$ se encuentran en el globo pálido, sustancia nigra, septum, núcleos amigdaloides central y medial, núcleo del lecho de la estría terminal. La subunidad $\gamma 3$ se expresa escasamente en la mayoría de las regiones del cerebro, con mayores niveles de expresión en la corteza cerebral y núcleo geniculado medial. La subunidad $\delta$ está co-distribuida con la subunidad $\alpha 4$ y es más abundante en las células granulares del cerebelo, tálamo, capa molecular del giro dentado, subculículo, corteza cerebral y estriado. La subunidad $\varepsilon$ se localiza en áreas pre-óptica y septal y en varios núcleos hipotalámicos. La subunidad $\pi$ está presente en el hipocampo y en tejidos no neuronales, tales como el útero y ovarios. La subunidad $\theta$ exhibe un patrón restringido de expresión en neuronas monoaminérgicas y está enriquecida en el locus cerúleo (Laurie, Wisden et al. 1992; Pirker, Schwarzer et al. 2000).

Los receptores $\mathrm{GABA}_{\mathrm{A}}$ compuestos por diferentes subunidades presentan propiedades fisiológicas, farmacológicas y localizaciones subcelulares distintas (Fig. 5). La isoforma particular de la subunidad $\alpha$ es el principal determinante de la sensibilidad de los receptores a benzodiacepinas, principales moduladores alostéricos. Los receptores compuestos por las subunidades $\alpha 1, \alpha 2, \alpha 3$, o $\alpha 5$ junto con las subunidades $\beta$ y $\gamma$ son sensibles a la modulación por benzodiacepinas $y$, exceptuando a los que contienen la subunidad $\alpha 5$, poseen una localización principalmente sináptica mediando la inhibición fásica en el cerebro. Los receptores conteniendo las subunidades $\alpha 5 \beta \gamma$ están situados principalmente en regiones extrasinápticas y median la inhibición tónica. Los receptores compuestos por las subunidades $\alpha 4$ y $\alpha 6$ junto con las subunidades $\beta$ y $\delta$ son insensibles a la modulación por benzodiacepinas, poseen ubicación extrasináptica y median la inhibición 
tónica (Jacob, Moss et al. 2008). Además, hay receptores $\mathrm{GABA}_{\mathrm{A}}$ pre-sinápticos cuya activación regula la liberación de neurotransmisor (Engelman and MacDermott 2004).

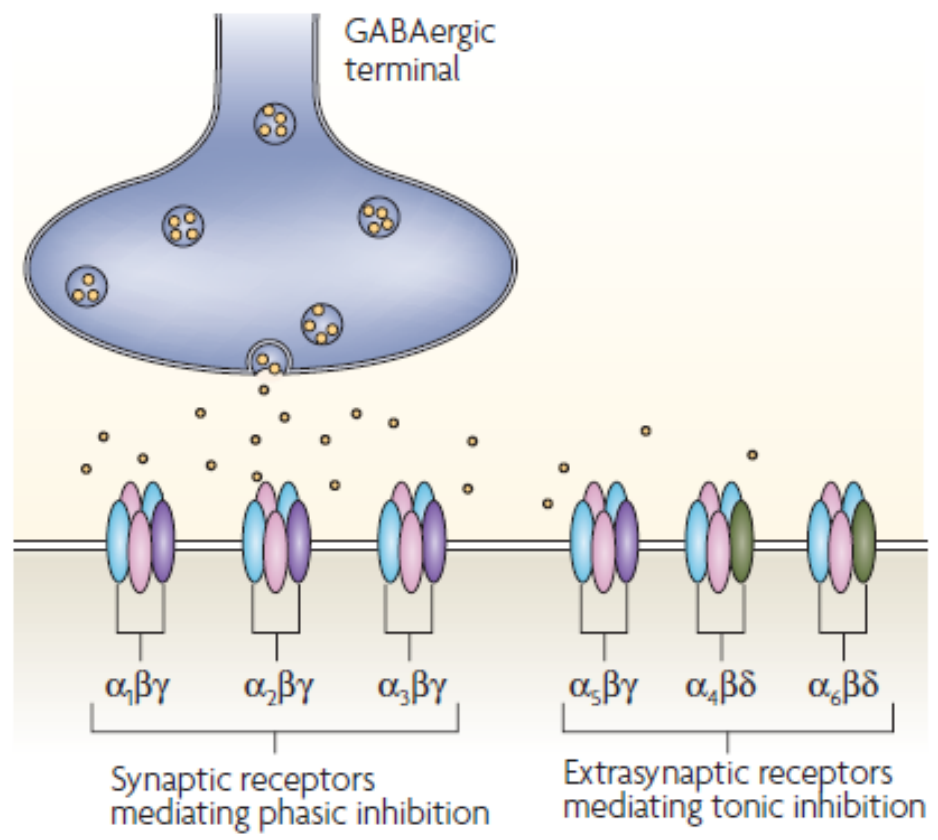

Figura 5: Localización del receptor $\mathbf{G A B A}_{\mathbf{A}}$. Los receptores conformados por las subunidades $\alpha$ (1-3) junto con las subunidades $\beta$ y $\gamma$ poseen localización principalmente sináptica. Los receptores conteniendo las subunidades $\alpha 5 \beta \gamma$ son mayoritariamente extrasinápticos. Los receptores formados por $\alpha(4,6)$ en combinación con $\beta$ y $\delta$ son insensibles a las benzodiacepinasy poseen localización extrasináptica. Tomado de Jacob, Mosset al. 2008.

\section{Drogas que interactúan con el receptor $\mathbf{G A B A}_{\mathbf{A}}$}

Los receptores $\mathrm{GABA}_{\mathrm{A}}$ son el blanco deacción de las benzodiacepinas, medicamentos usados para tratar la ansiedad e insomnio,que poseen también efectos anti-convulsivante y relajante muscular (efecto pre-anestésico) (Bateson 2004; Balon 2013). Además de las benzodiacepinas, los receptores $\mathrm{GABA}_{\mathrm{A}}$ son modulados por agentes anestésicos, tales como barbitúricos, alcoholes de cadena larga, esteroides neuroactivos, etomidato, propofol 
y también por etanol. Las acciones de estas drogas que modulan la actividad del receptor $\mathrm{GABA}_{\mathrm{A}}$ dependen en gran parte de la composición de subunidades del receptor con el cual interaccionan (Michels and Moss 2007) (Tabla 1).

\begin{tabular}{|c|c|}
\hline Subunidad & Propiedades farmacológicas \\
\hline$\alpha 1$ & $\begin{array}{l}\text { Acciones sedativas, amnésicas y anticonvulsivantes de las } \\
\text { benzodiacepinas }\end{array}$ \\
\hline$\alpha 2$ & $\begin{array}{c}\text { Efectos anxiolíticos y miorrelajantes (a dosis iniciales } \\
\text { mayores) de las benzodiacepinas. }\end{array}$ \\
\hline$\alpha 3$ & $\begin{array}{l}\text { Efectos ansiolíticos y miorrelajantes (a dosis altas) de las } \\
\text { benzodiacepinas. }\end{array}$ \\
\hline$\alpha 4$ & Sensibilidad al etanol. \\
\hline$\alpha 5$ & $\begin{array}{c}\text { Acciones amnésicas y miorrelajantes de las } \\
\text { benzodiacepinas. }\end{array}$ \\
\hline$\alpha 6$ & Sensibilidad al etanol. \\
\hline$\beta 1$ & Sin propiedades específicas \\
\hline$\beta 2$ & Acción anestésica del etomidato \\
\hline$\beta 3$ & Acción anestésica del propofol y etomidato \\
\hline$\gamma 1$ & Sin propiedades específicas \\
\hline$\gamma 2$ & Sin propiedades específicas \\
\hline$\gamma 3$ & Sin propiedades específicas \\
\hline
\end{tabular}


Tabla 1: Propiedades farmacológicas de los receptores $\mathrm{GABA}_{\mathrm{A}}$ conteniendo las principales subunidades. Modificado de Michels y Moss 2007.

Las características de los principales moduladores alostéricos del receptor $\mathrm{GABA}_{\mathrm{A}} \mathrm{se}$ describen a continuación:

\subsection{Neuroesteroides}

Entre los esteroides que regulan la función del receptor $\mathrm{GABA}_{\mathrm{A}}$ se encuentra una serie de compuestos llamados neuroesteroides, los cuales son sintetizados de novo a partir del colesterol en el tejido nervioso (neuronas y glía) constituyendo los moduladores endógenos más potentes del receptor (Akk, Covey et al. 2007; Herd, Belelli et al. 2007).

Ciertos neuroesteroides actúan como potenciadores de la función del receptor $\mathrm{GABA}_{\mathrm{A}}$ mientras que otros presentan función inhibitoria. Los más potentes neuroesteroides

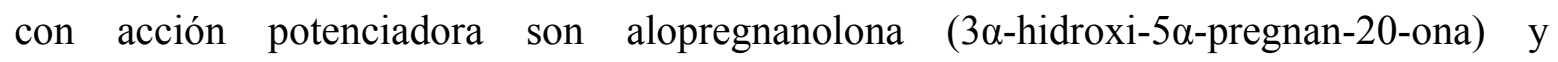

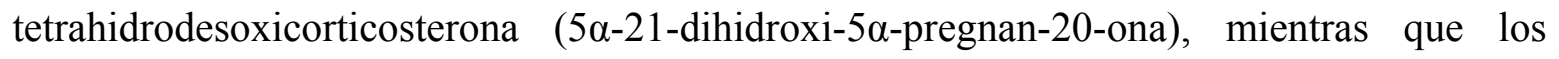

principales neuroesteroides inhibitorios son la pregnenolona sulfato y la dihidroepiandrosterona sulfato. A bajas concentraciones (nanomolares) los neuroesteroides con acción potenciadora aumentan la respuesta producida por GABA mientras que a altas concentraciones (sub- y micromolares) producen la apertura del canal en ausencia de GABA. Se identificaron residuos críticos para el aumento en la respuesta del GABA por neuroesteroides en la subunidad $\alpha$ y para la activación directa del receptor en la interfase entre las subunidades $\alpha$ y $\beta$. Por lo tanto, la acción modulatoria parecería estar mediada por un sitio de unión al receptor diferente del que media la apertura directa del canal. Si bien todos los receptores $\mathrm{GABA}_{\mathrm{A}}$ responden a los neuroesteroides, en los receptores conteniendo la subunidad $\delta$ el efecto máximo producido es mayor (Akk, Covey et al. 2007; Michels and Moss 2007). El efecto estimulatorio de las acciones del GABA por 
neuroesteroides se manifiesta como un aumento en la frecuencia de apertura del canal y en la probabilidad de entrada del canal a estados abiertos de larga duración que ocurren naturalmente (Herd, Belelli et al. 2007).

Los niveles endógenos de neuroesteroides no son estáticos sino que sufren oscilaciones en respuesta a una variedad de condiciones tales como: desarrollo, pubertad, estrés, preñez y ciclo menstrual. Perturbaciones en las concentraciones de neuroesteroides pueden contribuir al desarrollo de desórdenes neurológicos como la epilepsia catamenial y han sido implicadas en ciertas condiciones psicológicas tales como ataques de pánico, depresión mayor, depresión post-parto, tensión pre-menstrual y esquizofrenia (Herd, Belelli et al. 2007).

\subsection{Barbitúricos}

El pentobarbital fue sintetizado por E. Fischer de Bayer en 1911 y fue introducido en la clínica en 1912. Los barbitúricos han sido utilizados como ansiolíticos, sedativos, hipnóticos anestésicos y anticonvulsivantes (Estes 1995; Ito, Suzuki et al. 1996). Al igual que ciertos neuroesteroides, los barbitúricos potencian el efecto de GABA a concentraciones bajas y activan el receptor directamente a concentraciones altas. Estos dos efectos son mediados por la unión a dos sitios distintos en el receptor GABA $\mathrm{A}_{\mathrm{A}}$. La acción potenciadora de los barbitúricos se manifiesta prolongando el tiempo de apertura del canal de $\mathrm{Cl}^{-}$(Mehta and Ticku 1999).

A diferencia de las benzodiacepinas, la sensibilidad de los receptores $\mathrm{GABA}_{\mathrm{A}}$ a barbitúricos no parece depender de una composición de subunidades específica. Ha sido demostrado que receptores homoméricos conteniendo la subunidad $\beta 1$ expresados en oocitos de Xenopus son activados directamente por pentobarbital sugiriendo que la sensibilidad a barbitúricos no requiere la presencia de las subunidades $\alpha$ o $\gamma$. Sin embargo, la presencia de las subunidades $\delta$ o $\varepsilon$ sustituyendo a la subunidad $\gamma$ modifica drásticamente la respuesta a barbitúricos (Greenfield 2013). 


\subsection{Benzodiacepinas}

La primera benzodiacepina, clordiazepóxido, fue sintetizada por L. H. Sternbach y L.O. Randall en 1955 y sus propiedades hipnóticas y sedativas fueron descubiertas accidentalmente dos años después (Fig. 6). Unos años más tarde una benzodiacepina más potente, el diacepam, fue introducidaen la clínica. Posteriormente, numerosas benzodiacepinas y otros derivados fueron sintetizados y evaluados clínicamente (Fig. 7). Actualmente, aproximadamente 30 de estos compuestos son de uso clínico (Saari, UusiOukari et al. 2011).

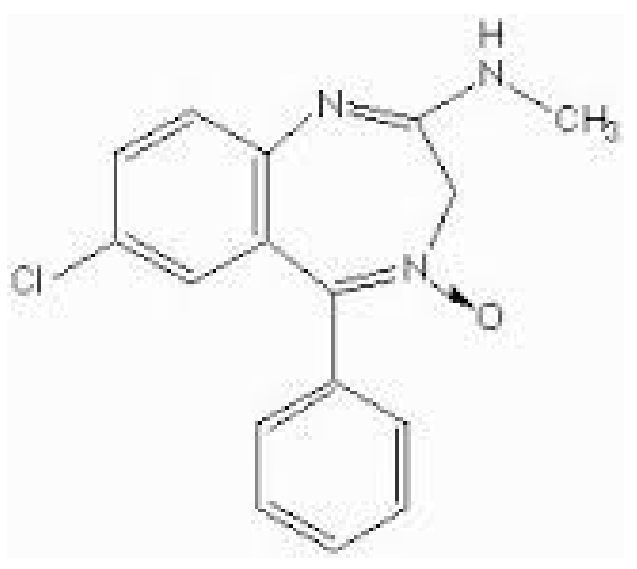

Figura 6: Estructura química del clordiacepóxido 

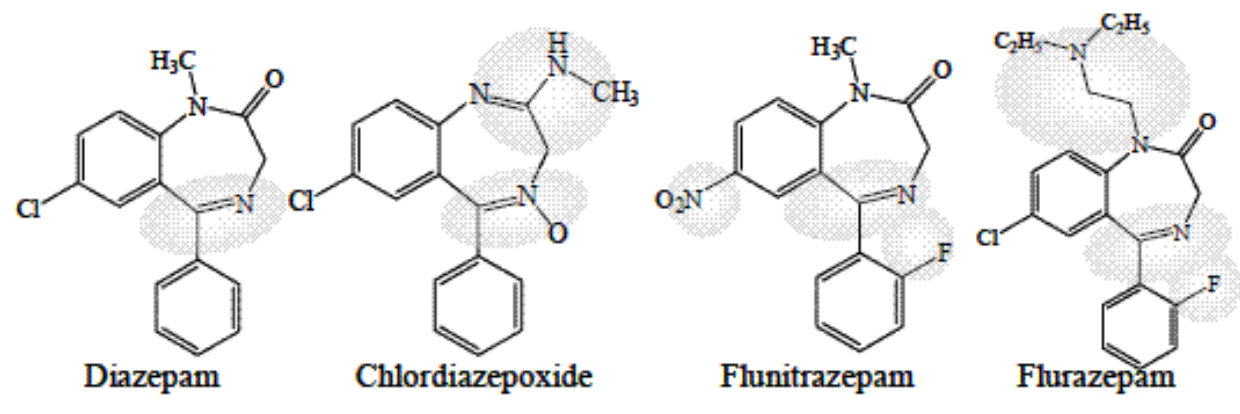<smiles>Clc1ccc2c(c1)C(c1ccccc1)=NCc1nncn1-2</smiles>

Estazolam<smiles>O=C1Nc2ccc(Cl)cc2C(c2ccccc2Cl)=NC1O</smiles>

Lorazepam<smiles>Cc1nnc2n1-c1ccc(Cl)cc1C(c1ccccc1)=NC2</smiles>

Alprazolam

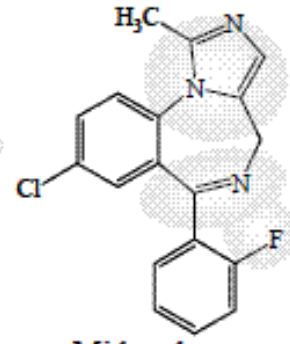

Midazolam<smiles>O=C(O)C1N=C(c2ccccc2)c2cc(Cl)ccc2NC1=O</smiles>

Quazepam

Clorazepate

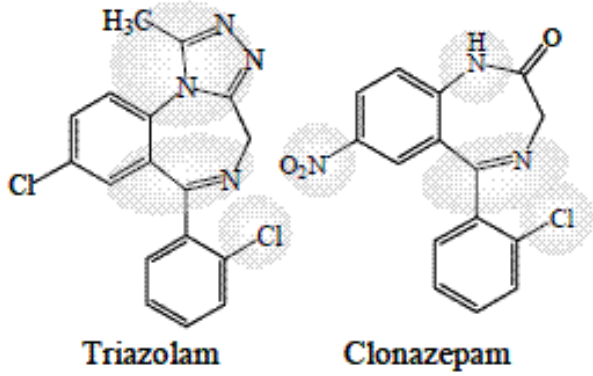

Figura 7: Estructura química de las principales benzodiacepinas

Las benzodiacepinas presentan una amplia variedad de acciones terapéuticas, incluyendo: ansiólisis, sedación, relajacion muscular, induccion del sueño, y como anticonvulsivantes. Como fármacos sedantes-hipnóticos, han reemplazado esencialmente a los barbitúricos, debido a un alto índice terapéutico y baja toxicidad (Saari, Uusi-Oukari et al. 2011).

Las benzodiacepinas median su acción a través de un sitio de unión modulador (el sitio de benzodiacepina) que se encuentra en la interfase de los dominios amino terminal, 
ubicados entre la subunidad $\alpha$ y la subunidad $\gamma$ de los receptores GABA (Berezhnov D. 2007). Estos compuestos potencian el influjo de $\mathrm{Cl}^{-}$inducido por GABA aumentando la frecuencia de apertura del canal. En contraste con los barbitúricos, la modulación del receptor GABA por benzodiacepinas es auto-limitante: la conductancia del canal en presencia de GABA y benzodiacepinas no es mayor que la conductancia inducida por altas concentraciones de GABA solo. Por otra parte, también en contraste con los barbitúricos, las benzodiacepinas no abren los canales de cloro en ausencia de GABA (Rudolph and Knoflach 2011).

Existen tres clases principales de ligandos del sitio de unión de benzodiacepinas: moduladores positivos ("agonistas") los cuales son anticonvulsivantes y ansiolíticos, moduladores negativos ("agonistas inversos") que son convulsivantes y ansiogénicos y moduladores neutros ("antagonistas") que no producen efectos pero que bloquean los efectos de los moduladores positivos y negativos. Actualmente existen compuestos abarcando el espectro completo de eficacias desde moduladores positivos a moduladores negativos (Fig. 8) (Haefely, Martin et al. 1993).

Las benzodiacepinas potencian las respuestas del GABA a concentraciones no saturantes de GABA, mediante un aumento en la afinidad del neurotransmisor por el receptor. Dado que este efecto no está acompañado por un aumento en la eficacia de apertura del canal, se postuló originalmente que las benzodiacepinas actúan únicamente aumentado la afinidad de los agonistas del sitio de unión de GABA. Sin embargo, este concepto clásico ha ido cambiando ya que se demostró que "agonistas" benzodiacepínicos potencian las respuestas inducidas por concentraciones saturantes de agonistas parciales del sitio de unión de GABA y abren directamente el canal de receptores $\mathrm{GABA}_{\mathrm{A}}$ mutantes que son espontáneamente activos (Bianchi and Macdonald 2001; Downing, Lee et al. 2005). Más recientemente, ha sido demostrado que las benzodiacepinas pueden modular positivamente la función del receptor por medio del "desplazamiento" del equilibrio entre los receptores unidos al neurotransmisor en reposo y los receptores en estado pre-activado previo a la apertura del canal (Gielen, Lumb et al. 2012). 


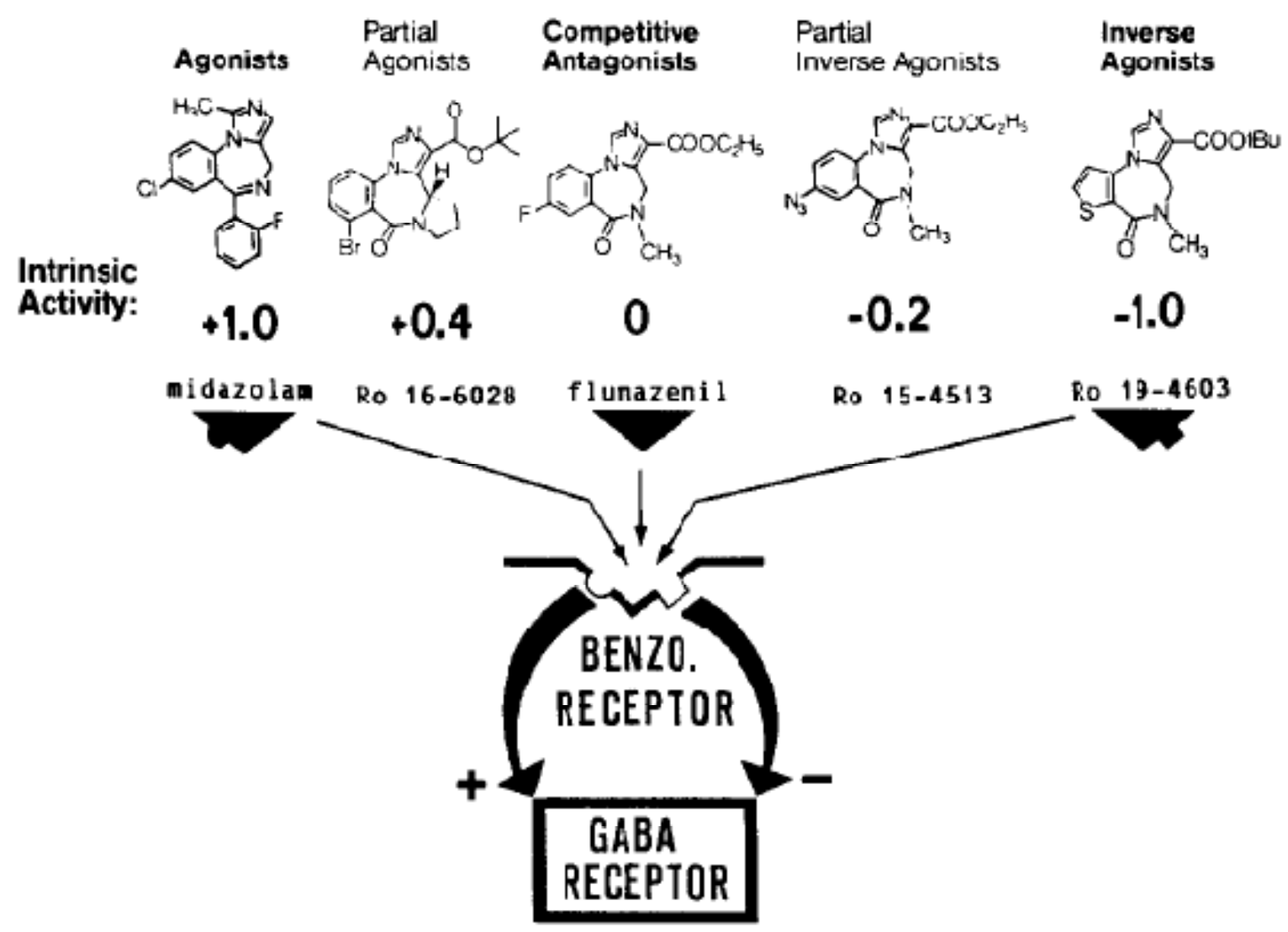

Figura 8: Ligandos del sitio de unión de benzodiacepinas en el receptor $\mathrm{GABA}_{\mathrm{A}}$ con diferentes eficacias. Tomado de Haefely, Martin et al. 1993

La mayoría de las benzodiacepinas clásicas se unen con similar afinidad a receptores conteniendo la subunidad $\alpha 1, \alpha 2, \alpha 3$ o $\alpha 5$ en combinación con las subunidades $\beta \gamma 2$. En contraste, varios compuestos no benzodiacepínicos que se unen al sitio de las benzodiacepinas, tales como zolpidem y zaleplon, tienen alta afinidad por receptores $\alpha 1 \beta \gamma 2$ y afinidad intermedia por receptores conteniendo las subunidades $\alpha 2$ y $\alpha 3$. El zolpidem tiene afinidad muy baja por receptores conteniendo las subunidades $\alpha 5 \beta \gamma 2$ (Saari, UusiOukari et al. 2011). 
Por otro lado, la eficacia con la cual las benzodiacepinas clásicas potencian la acción del GABA depende del subtipo de subunidad $\alpha$ presente en el receptor, con el siguiente orden: $\alpha 3>\alpha 1 / \alpha 5$ (Puia, Vicini et al. 1991; Wafford, Whiting et al. 1993; Smith, Alder et al. 2001).

\section{Tolerancia a los efectos farmacológicos de las benzodiacepinas}

Distintas líneas de evidencias indican la existencia de mecanismos homeostáticos que controlan la inhibición sináptica a través de cambios en el número, estructura y/o función de los receptores $\mathrm{GABA}_{\mathrm{A}}$ postsinápticos. La actividad neuronal regula la ubiquitinación y degradación por el sistema ubiquitina-proteosoma en el retículo endoplasmático, produciendo alteraciones en la expresión del receptor en la superficie celular (Saliba, Michels et al. 2007). La actividad neuronal también controla la inserción (Saliba, Kretschmannova et al. 2012) y las propiedades de difusión de los receptores $\mathrm{GABA}_{\mathrm{A}}$ (Bannai, Levi et al. 2009) en la membrana celular. La regulación del receptor $\mathrm{GABA}_{\mathrm{A}}$ inducida por la activación del propio receptor es también una forma de plasticidad homeostática que es relevante en condiciones fisiológicas, patológicas, de consumo de drogas y farmacológicas. En condiciones fisiológicas tales como el ciclo menstrual y preñez, en las cuales los receptores $\mathrm{GABA}_{\mathrm{A}}$ están continuamente expuestos a altas concentraciones de alopregnanolona, se desencadena un mecanismo de tolerancia acompañado por alteraciones selectivas en las subunidades del receptor $\mathrm{GABA}_{\mathrm{A}}$ (Turkmen, Backstrom et al. 2011). La regulación dependiente del uso de los receptores $\mathrm{GABA}_{\mathrm{A}}$ es aún más evidente bajo ciertas condiciones patológicas. Por ejemplo, las neuronas GABAérgicas disparan a muy alta frecuencia $(800 \mathrm{~Hz})$ durante accesos epilépticos en gatos (Timofeev, Grenier et al. 2002). Además, se han observado alteraciones en la expresión de ciertas subunidades del receptor $\mathrm{GABA}_{\mathrm{A}}$ durante la epileptogénesis en modelos de epilepsia en roedores (Brooks-Kayal, Shumate et al. 1998; Brooks-Kayal, Raol et al. 2009). El consumo prolongado de etanol induce tolerancia a los efectos ansiolíticos, sedativos y de incoordinación motora del etanol. Esta tolerancia está acompañada por alteraciones en los niveles de algunas subunidades del receptor GABA $_{A}$ (Devaud LL 1997). 
En cuanto a las benzodiacepinas, existen evidencias que indican que pacientes que consumen estas drogas crónicamente sufren diferentes trastornos tales como déficits cognitivos, problemas de coordinación motora y de memoria. Uno de los problemas más comúnmente reportado como consecuencia de la administración prolongada de estos fármacos es el desarrollo de tolerancia a sus efectos farmacológicos y dependencia (Bateson 2002). La tolerancia inducida por el tratamiento crónico con benzodiacepinas constituye un mecanismo de adaptación, y puede por lo tanto ser considerado como un ejemplo de plasticidad neuronal.

El fenómeno de la tolerancia es complejo ya que se desarrolla siguiendo diferentes cursos temporales y presenta distintos grados dependiendo del efecto farmacológico analizado. La tolerancia a los efectos sedativos se desarrolla más rápidamente que a los efectos anticonvulsivantes. En cuanto a los efectos ansiolíticos, la tolerancia no se observó en todos los modelos animales y si se observa parece manifestarse luego de un período de tiempo de administración aún más largo. Además, ha sido difícil demostrar la tolerancia a los efectos ansiolíticos de las benzodiacepinas en humanos. Por lo tanto, se ha hipotetizado la existencia de diferentes mecanismos de tolerancia dependiendo del efecto farmacológico, o del subtipo de receptor $\mathrm{GABA}_{\mathrm{A}}$ activado y de la región del cerebro involucrada. Es posible también que múltiples mecanismos adaptativos coexistan, lo cual complica aún más el estudio de la tolerancia a las benzodiacepinas (Bateson 2002; Vinkers and Olivier 2012).

Los distintos subtipos de subunidades $\alpha$ del receptor $\mathrm{GABA}_{\mathrm{A}}$ parecen contribuir diferencialmente al desarrollo de tolerancia a los efectos farmacológicos de las benzodiacepinas. Ha sido demostrado que el tratamiento crónico de ratones con diacepam, una benzodiacepina no selectiva por los receptores $\mathrm{GABA}_{\mathrm{A}}$ conteniendo los diferentes subtipos de subunidad $\alpha$, produce tolerancia a los efectos ansiolíticos, hipotérmicos y sedativos del diacepam. En ratones tratados crónicamente con bretazenil, un modulador alostérico positivo parcial no selectivo, se desarrolla tolerancia a los efectos ansiolíticos e hipotérmicos pero no a los efectos sedativos del diacepam. El tratamiento crónico en ratones con zolpidem, selectivo por receptores conteniendo la subunidad $\alpha 1$, induce tolerancia a los efectos hipotérmicos del diacepam, tolerancia parcial a los efectos ansiolítcos y ninguna tolerancia a los efectos sedativos del diacepam. Finalmente, el 
tratamiento crónico con TPA023, selectivo por receptores conteniendo las subunidades $\alpha 2 / 3$, no produce tolerancia a los efectos ansiolíticos, hipotérmicos o sedativos del diacepam (Vinkers, van Oorschot et al. 2012). Estos resultados sugieren que el desarrollo de tolarancia a los efectos sedativos del diacepam necesita la activación conjunta de receptores $\mathrm{GABA}_{\mathrm{A}}$ conteniendo las subunidades $\alpha 1$ y $\alpha 5$. Estos resultados están de acuerdo a estudios realizados con ratones modificados genéticamente en los cuales una mutación puntual en las subunidades $\alpha 1, \alpha 2, \alpha 3$ o $\alpha 5$ del receptor $\mathrm{GABA}_{\mathrm{A}}$ resulta en insensibilidad al diacepam. En ratones salvajes y ratones con la mutación en las subunidades $\alpha 2$ o $\alpha 3$ del receptor, el tratamiento crónico con diacepam produce una gran disminución en el efecto sedativo del diacepam, medido como una reducción en la actividad motora. Los ratones con la mutación en la subunidad $\alpha 1$ no presentan ninguna modificación en la actividad motora con el tratamiento crónico con diacepam mientras que los ratones con la mutación en la subunidad $\alpha 5$ no desarrollan tolerancia a los efectos sedativos del diacepam. De este modo, estos experimentos también sugieren que la activación crónica de receptores conteniendo las subunidades $\alpha 1$ y $\alpha 5$ es crucial para el desarrollo de tolerancia a los efectos sedativos del diacepam (van Rijnsoever, Tauber et al. 2004).

Existen evidencias sugiriendo que alteraciones farmacocinéticas no contribuyen fundamentalmente al desarrollo de tolerancia a las benzodiacepinas. Ha sido reportado que un tratamiento con diacepam en ratas durante 7 días indujo tolerancia a los efectos sedativos a pesar de que las concentraciones en suero de diacepam eran mayores que luego de la administración aguda (Fernandes, File et al. 1996). Por otro lado, no se observaron diferencias en los niveles plasmáticos de diacepam luego de una administración aguda entre pacientes tratados previamente en forma crónica con alprazolam y pacientes no tratados, a pesar de que se observó tolerancia al efecto amnésico y sedante (Cowley, Roy-Byrne et al. 1995). El candidato más importante para mediar los cambios adaptativos producidos por el tratamiento crónico con benzodiacepinas parece ser el receptor $\mathrm{GABA}_{\mathrm{A}}$. 
Introducción

\section{Alteraciones del receptor $\mathrm{GABA}_{\mathrm{A}}$ inducidas por la exposición prolongada a benzodiacepinas}

\subsection{Cambios en el número de receptores $\mathrm{GABA}_{\mathrm{A}}$}

La disminución en el número de receptores $\mathrm{GABA}_{\mathrm{A}}$ como consecuencia de la exposición prolongada a benzodiacepinas es un mecanismo potencial de tolerancia. Si bien algunos estudios reportaron una disminución en el número de receptores $\mathrm{GABA}_{\mathrm{A}}$ inducida por la administración crónica de fluracepam en ratas (Rosenberg and Chiu 1979; Rosenberg and Chiu 1981), se usaron concentraciones muy elevadas de benzodiacepina. En contraste, experimentos realizados en una línea celular expresando receptores $\mathrm{GABA}_{\mathrm{A}}$ recombinantes sugieren que el tratamiento prolongado con diacepam induce un aumento en el número de receptores (Pericic, Atrac et al. 2007). Sin embargo, estos últimos resultados no fueron reproducidos cuando se estudiaron receptores $\mathrm{GABA}_{\mathrm{A}}$ nativos. La mayoría de los trabajos indican que los tratamientos prolongados con benzodiacepinas, tanto in vivo (Gallager, Lakoski et al. 1984; Brett and Pratt 1995) como ex vivo (en cultivos neuronales, Fig. 9) (Roca, Schiller et al. 1990), no inducen cambios en el número de receptores $\mathrm{GABA}_{\mathrm{A}}$. 


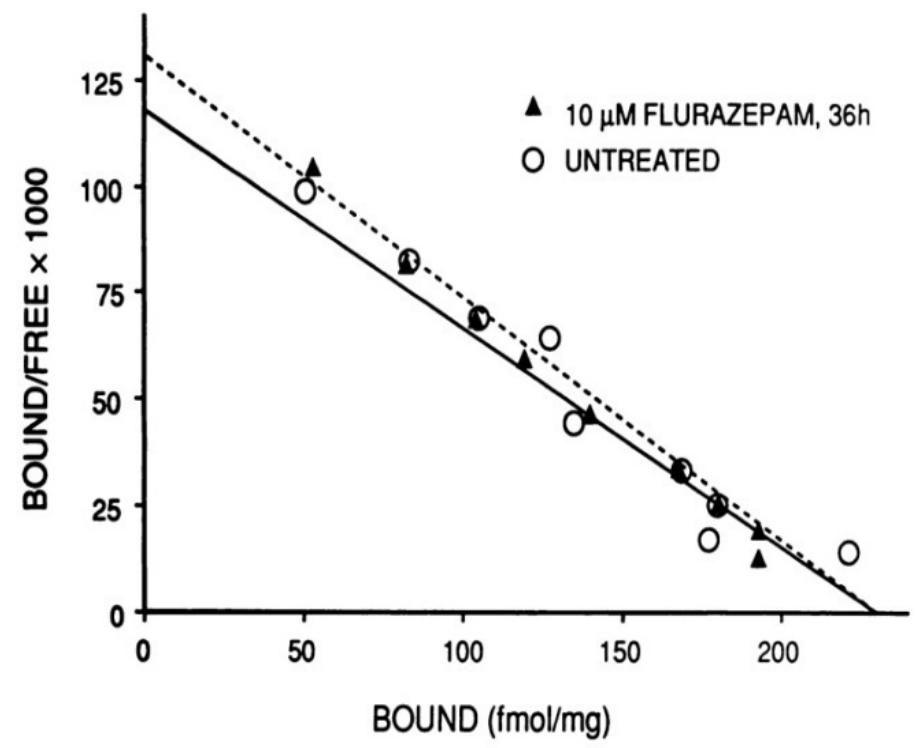

Figura 9: La exposición crónica de cultivos neuronales a fluracepam no modifica la unión máxima de [ $\left.{ }^{3} \mathbf{H}\right]$ flunitracepam. Tomado de Roca, Schiller et al. 1990.

\subsection{Desacoplamiento}

Exposiciones prolongadas de cultivos corticales a GABA y moduladores alostéricos positivos, tales como benzodiacepinas, neuroesteroides, barbitúricos y etanol, inducen una disminución de la interacción alostérica entre los sitios de unión a GABA y a benzodiacepinas, fenómeno llamado desacoplamiento (Roca, Rozenberg et al. 1990; Roca, Schiller et al. 1990; Prasad and Reynolds 1992; Lyons, Gibbs et al. 2000) (Fig. 10). El desacoplamiento inducido por benzodiacepinas ha sido también observado en diferentes líneas celulares que expresan receptores $\mathrm{GABA}_{\mathrm{A}}$ recombinantes. Los cursos temporales reportados varían desde minutos en células PA3 a horas en células WSS-1 (Klein, Whiting et al. 1994; Wong, Lyon et al. 1994).

Por otro lado, se ha observado que tratamientos prolongados con benzodiacepinas en roedores in vivo producen tolerancia a sus efectos farmacológicos junto con desacoplamiento de las interacciones alostéricas del receptor. El desacoplamiento ha sido detectado como una reducción tanto en la capacidad de las benzodiacepinas para potenciar 
las acciones del GABA como en la habilidad del GABA para estimular la unión de benzodiacepinas (Gallager, Lakoski et al. 1984; Marley and Gallager 1989; Tietz, Chiu et al. 1989; Tietz, Zeng et al. 1999).

Ha sido demostrado que la administración crónica in vivo en ratas con flumacenil, "antagonista" del sitio de unión de las benzodiacepinas, no induce desacoplamiento mientras que el resto de los ligandos produce diferentes grados de desacoplamiento que están correlacionados con sus eficacias (Hernandez, Heninger et al. 1989).

Si bien se ha sugerido que el desacoplamiento es uno de los posibles mecanismos responsable del desarrollo de la tolerancia a las benzodiacepinas, no ha sido aún demostrado. Las bases moleculares del desacoplamiento aún se desconocen.

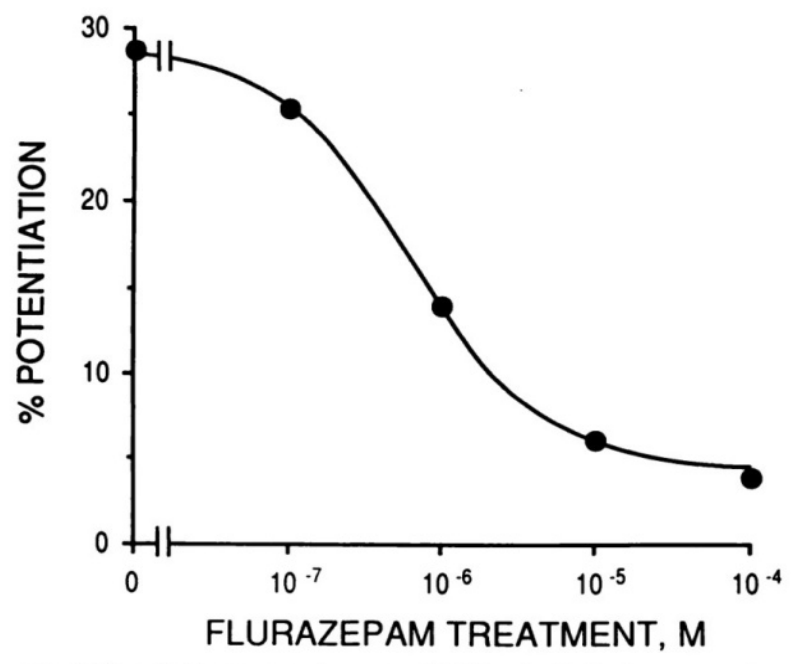

Figura 10: El tratamiento crónico con fluracepam en cultivos neuronales disminuye la potenciación de la unión de $\left[^{3} \mathrm{H}\right]$ flunitracepam por GABA en una manera concentracióndependiente. Tomado de Roca et al. 1990 


\subsection{Cambios en la composición de las subunidades del receptor}

A pesar de que la administración prolongada de benzodiacepinas no parece inducir alteraciones en el número de receptores $\mathrm{GABA}_{\mathrm{A}}$, numerosos estudios demuestran que estos tratamientos producen cambios selectivos en los niveles de ARNm y proteína de las subunidades del receptor en ciertas áreas del cerebro (Uusi-Oukari and Korpi 2010). Por lo tanto, un posible mecanismo de tolerancia es un cambio en la composición de subunidades del receptor $\mathrm{GABA}_{\mathrm{A}}$.

Los resultados reportados son bastante confusos y parecen variar de acuerdo al tratamiento crónico empleado. Por ejemplo, ha sido demostrado que los niveles de la subunidad $\alpha 1$ en la corteza cerebral de rata disminuyen (Pesold, Caruncho et al. 1997; Chen, Huang et al. 1999), no cambian (Wu, Rosenberg et al. 1994) o aumentan (Pratt, Brett et al. 1998) dependiendo del tratamiento crónico. Además, las alteraciones en las subunidades parecen ser específicas de la región del cerebro. De este modo, ha sido descripto que la administración subcutánea de diacepam durante 21 días en rata induce una disminución en los niveles de $\alpha 1$ en el hipocampo pero no produce ninguna modificación en esta subunidad en la corteza cerebral (Wu, Rosenberg et al. 1994).

Hasta la fecha no se ha investigado directamente el efecto de la administración crónica de benzodiacepinas sobre la composición de subunidades del receptor $\mathrm{GABA}_{\mathrm{A}}$. Ha sido reportado que la exposición prolongada de cultivos de hipocampo de rata a fluracepam durante 24 horas induce un aumento en la degradación lisosomal de receptores $\mathrm{GABA}_{\mathrm{A}}$ conteniendo la subunidad $\alpha 2$ luego de su endocitosis, que conduce a una reducción en la eficacia de la inhibición sináptica (Jacob, Michels et al. 2012). Estos resultados sugieren que la exposición prolongada con benzodiacepinas produce un cambio en el tráfico de

receptores $\mathrm{GABA}_{\mathrm{A}}$ selectivo con respecto al subtipo de receptor que resulta en una reducción en el número de receptores conteniendo la subunidad $\alpha 2$ en la superficie celular. Por lo tanto, la exposición crónica de fluracepam resultaría en un cambio en la composición de subunidades del receptor $\mathrm{GABA}_{\mathrm{A}}$ en la membrana post-sináptica. 


\subsection{Modificaciones post-traduccionales del receptor}

La fosforilación de los receptores de neurotransmisores es un mecanismo potencial de plasticidad en el sistema nervioso. El bucle intracelular mayor (ubicado entre las regiones TM3 y TM4) de ciertas subunidades del receptor GABA $_{A}$ puede ser fosforilado en residuos serina, treonina y tirosina por una variedad de proteínas quinasas tales como la proteína quinasa $\mathrm{A}$ (PKA), C (PKC), tirosina quinasa Src, Fyn y quinasa dependiente de $\mathrm{Ca}^{2+} /$ calmodulina tipo II (CaMKII) (Moss and Smart 1996). Las subunidades $\beta 1-3$ poseen sitios de fosforilación en treonina y serina, mientras que la subunidad $\gamma 2$, puede ser fosforilada en residuos treonina, serinay tirosina (Moss, Doherty et al. 1992; Jurd, Tretter et al. 2010). Un mismo residuo puede ser fosforilado por más de una proteína quinasa. En la Figura 11 se resumen los sitios de fosforilación principales del receptor $\mathrm{GABA}_{\mathrm{A}}$.

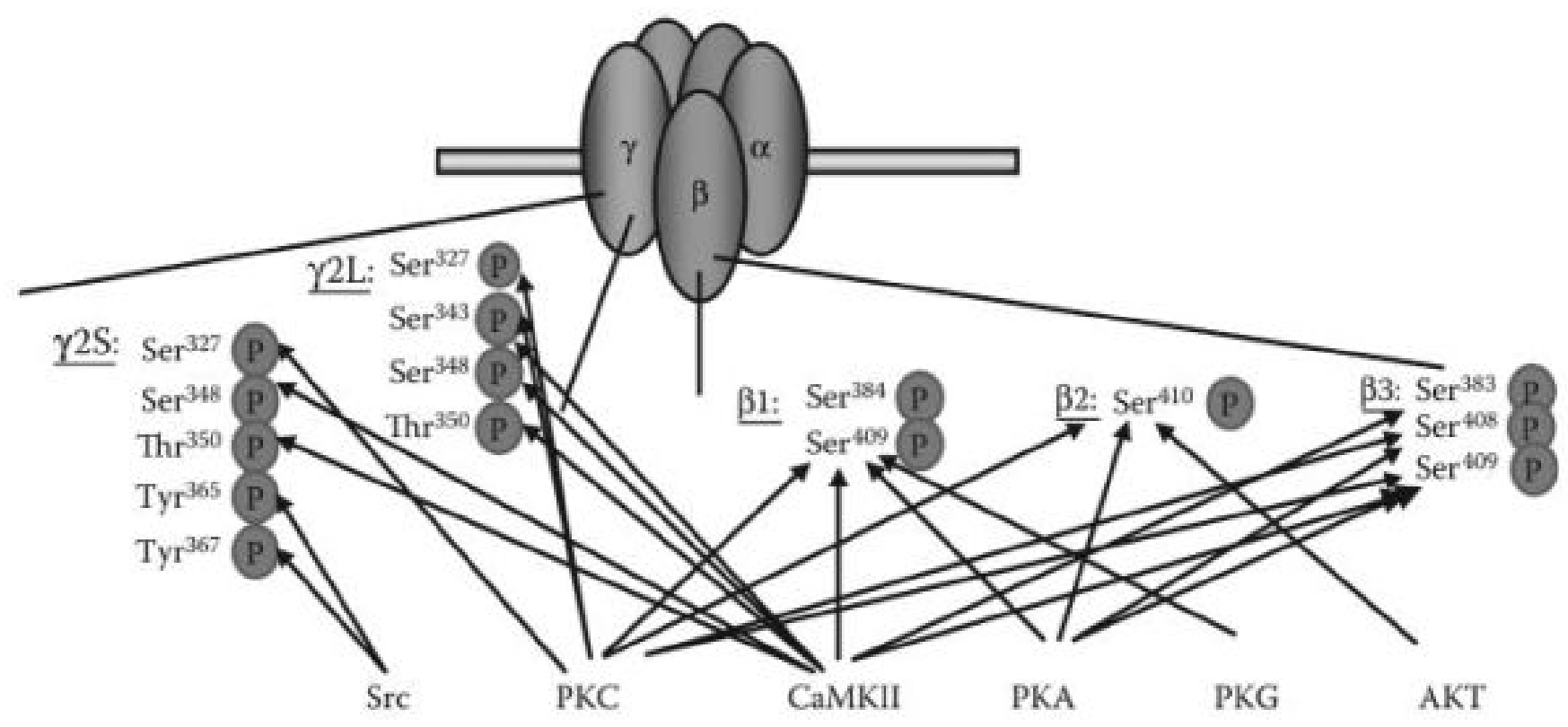

Figura 11: Fosforilación de las subunidades del receptor $\mathbf{G A B A}_{\mathbf{A}}$. PKA: proteína quinasa dependiente de AMPc; PKC: proteína quinasa dependiente de calcio; PKG: proteína quinasa dependiente de GMPc; CaMKII: proteína quinasa dependiente de calcio y calmodulina; Src: proteína quinasa de sarcoma; AKT: proteína quinasa de serina/treonina. 
Numerosos estudios han descripto que la fosforilación puede estimular o inhibir la función del receptor $\mathrm{GABA}_{\mathrm{A}}$ dependiendo de su composición de subunidades. Por ejemplo, la fosforilación de la serina 409 de la subunidad $\beta 1$ inhibe las corrientes evocadas por GABA, mientras que la fosforilación del residuo equivalente de la subunidad $\beta 3$ estimula la actividad del receptor (McDonald, Amato et al. 1998; Houston, Lee et al. 2007; Houston, He et al. 2009).

La acción de los moduladores alostéricos del receptor $\mathrm{GABA}_{\mathrm{A}}$ es modificada por la actividad de proteínas quinasas. Algunos estudios sugieren que la activaciónde PKC aumenta la estimulación por benzodiacepinas, barbitúricos y neuroesteroides de las corrientes evocadas por GABA en oocitos de Xenopus (Leidenheimer, Whiting et al. 1993; Leidenheimer and Chapell 1997). En contraste, resultados de otros grupos de investigación, realizados en células de tipo neuronal NT2-N, indican que la activación de PKC produce una disminución en la potencia de las benzodiacepinas para estimular la acción del GABA (Gao and Greenfield 2005). Además, ratones modificados genéticamente que carecen de $\mathrm{PKC} \varepsilon$ son más sensibles a los efectos comportamentales agudos de barbitúricos, benzodiacepinas y neuroesteroides (Hodge, Mehmert et al. 1999). Estas observaciones sugieren que $\mathrm{PKC} \varepsilon$ inhibe la regulación del receptor $\mathrm{GABA}_{\mathrm{A}}$ por moduladores alostéricos positivos.

La fosforilación regula además el tráfico intracelular de los receptores. La endocitosis del receptor $\mathrm{GABA}_{\mathrm{A}}$ es un mecanismo dependiente de clatrina y está mediada por la interacción de la proteína adaptadora de clatrina AP2 y las subunidades $\beta, \gamma$ y $\delta$ del receptor. La fosforilación de ciertos residuos en el bucle intracelular de estas subunidades inhibe su interacción con AP2 y previene de este modo la internalización de los receptores aumentando el número de receptores en la membrana plasmática (Comenencia-Ortiz, Moss et al. 2014). Las vías de señalización que controlan el estado de fosforilación del receptor no se conocen completamente.

Ciertos estudios indican que el efecto de los tratamientos crónicos con benzodiacepinas sobre el receptor $\mathrm{GABA}_{\mathrm{A}}$ está mediado por la activación de diferentes 
proteínas quinasas. Experimentos de exposición crónica a diacepam en líneas celulares expresando receptores recombinantes sugieren que la activación de PKA regula la función del receptor $\mathrm{GABA}_{\mathrm{A}}$ (Ali and Olsen 2001). Por otro lado, estudios realizados en cultivos de cerebelo indican que la activación de PKC está involucrada en la regulación de los niveles de las subunidades del receptor $\mathrm{GABA}_{\mathrm{A}}$ inducida por la exposición a fluracepam (Johnston, Price et al. 1998). No ha sido demostrado que los efectos de la administración crónica con benzodiacepinas estén mediados por cambios en el estado de fosforilación del receptor $\mathrm{GABA}_{\mathrm{A}}$.

\subsection{Rol de los canales de calcio activados por voltaje}

La exposición prolongada a moduladores alostéricos positivos del receptor $\mathrm{GABA}_{\mathrm{A}}$, tales como benzodiacepinas y etanol, y otras drogas de abuso, modulan los canales de $\mathrm{Ca}^{2+}$ dependientes de voltaje (CCDV) (Walter and Messing 1999; Rajadhyaksha and Kosofsky 2005). En particular, la administración crónica de benzodiacepinas potencia las corrientes de $\mathrm{Ca}^{2+}$ mediadas por los CCDV de tipo L (CCDV-L) en neuronas de hipocampo del área CA1 (Xiang, Earl et al. 2008). Además, la reducción en las corrientes mediadas por el receptor $\mathrm{GABA}_{\mathrm{A}}$ inducida por la administración crónica de benzodiacepinas en hipocampo es bloqueada por inhibidores de los CCDV-L (Xiang and Tietz 2008). Estas evidencias sugieren que el mecanismo de tolerancia a las benzodiacepinas estaría mediado por vías de señalización activadas por los CCDV-L.

\section{Antecedentes de la línea de investigación}

La ocupación continua del receptor $\mathrm{GABA}_{\mathrm{A}}$ por diferentes ligandos desencadena una serie de mecanismos conocidos como regulación dependiente del uso. Las bases moleculares de esta regulación dependiente de la activación de los receptores $\mathrm{GABA}_{\mathrm{A}}$ han sido principalmente investigadas en cultivos celulares. Resultados previos de nuestro laboratorio demuestran que la exposición de cultivos neuronales primarios de corteza

cerebral de rata a GABA durante 5-10 minutos $\left(t_{1 / 2}=3 \mathrm{~min}\right)$ inicia un proceso que resulta 
en desacoplamiento entre los sitios de unión de GABA y benzodiacepinas 24-48 horas más tarde $\left(\mathrm{t}_{1 / 2}=12\right.$ horas) (Gravielle, Faris et al. 2005) (Fig. 12). Este proceso regulatorio ocurre en ausencia de cambios en el número de receptores GABA $\mathrm{A}_{\mathrm{A}}$. La etapa inicial del desacoplamiento es inhibida por picrotoxina, un bloqueante del canal de $\mathrm{Cl}^{-}$, indicando que este fenómeno regulatorio depende de la activación del receptor $\mathrm{GABA}_{\mathrm{A}}$. En trabajos más recientes hemos demostrado que el desacoplamiento inducido por la breve activación del receptor $\mathrm{GABA}_{\mathrm{A}}$ en cultivos neuronales de corteza cerebral de rata está acompañado por una disminución en el porcentaje de receptores $\mathrm{GABA}_{\mathrm{A}}$ conteniendo la subunidad $\alpha 3$, un subtipo de receptores que exhibe el mayor grado de acoplamiento entre los sitios de unión de GABA y benzodiacepinas, sugiriendo que el desacoplamiento es el resultado de un cambio en la composición de subunidades del receptor (Gutiérrez, Ferreri et al. 2014). Además, nuestros resultados indican que el desacoplamiento está mediado por un aumento

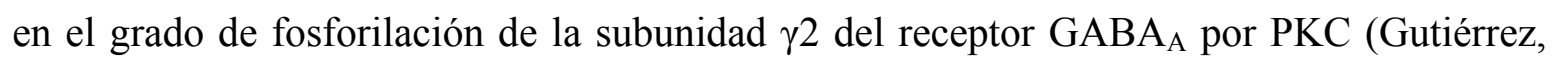
Ferreri et al. 2014). 


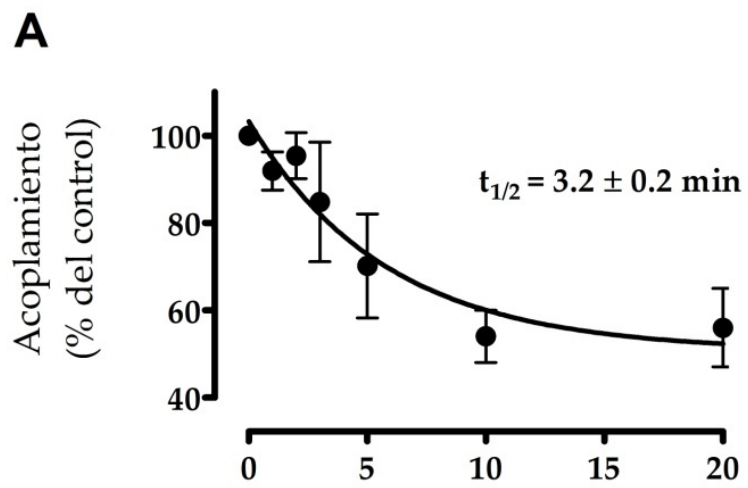

Exposición a GABA, minutos

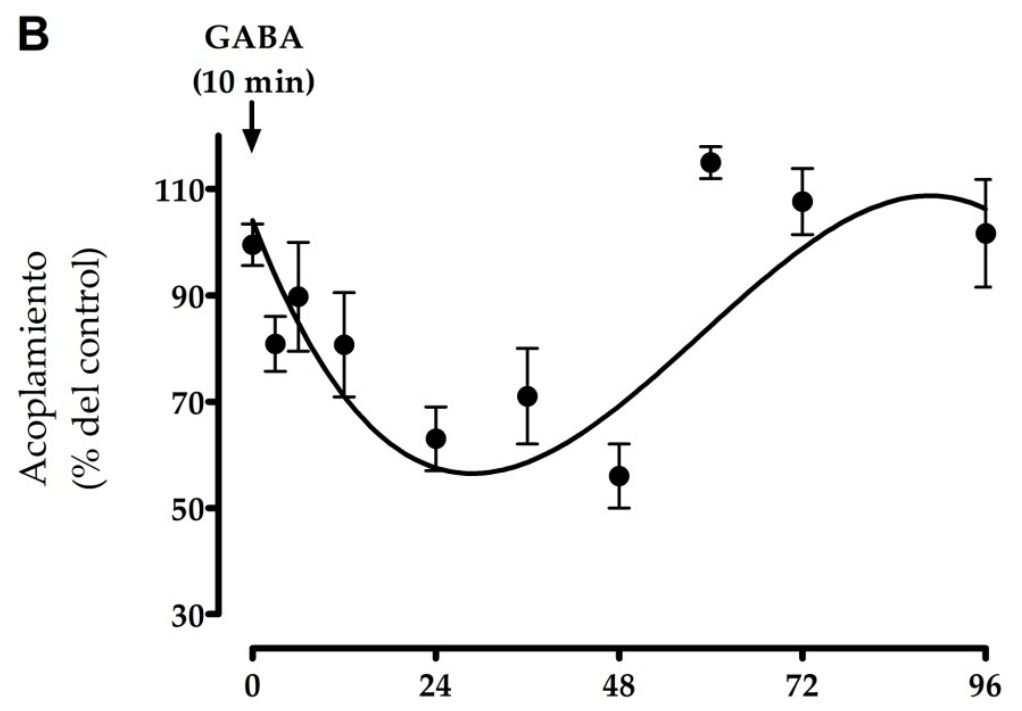

Tiempo post-exposición, horas

Figura 12: Curso temporal del desacoplamiento entre los sitios de unión a GABA y a benzodiacepinas inducido por una breve exposición a GABA. A Cultivos neuronales incubados con GABA $1 \mathrm{mM}$ durante los tiempos indicados y cosechados 48 horas más tarde. B Cultivos incubados con GABA $1 \mathrm{mM}$ durante 10 minutos y luego cosechados a los tiempos indicados. Tomado de Gravielle, Faris et al. 2005.

La exposición crónica de cultivos neuronales a GABA durante 48 horas también induce desacoplamiento entre los sitios de unión de GABA y benzodiacepinas pero a 
diferencia de la exposición breve, produce además una reducción en el número de receptores $\mathrm{GABA}_{\mathrm{A}}\left(\mathrm{t}_{1 / 2}=24-25\right.$ horas) (Roca, Rozenberg et al. 1990). La disminución en el número de receptores está mediada por la represión transcripcional de los genes que codifican las subunidades del receptor a través de la activación de CCDV-L (Fig. 13).

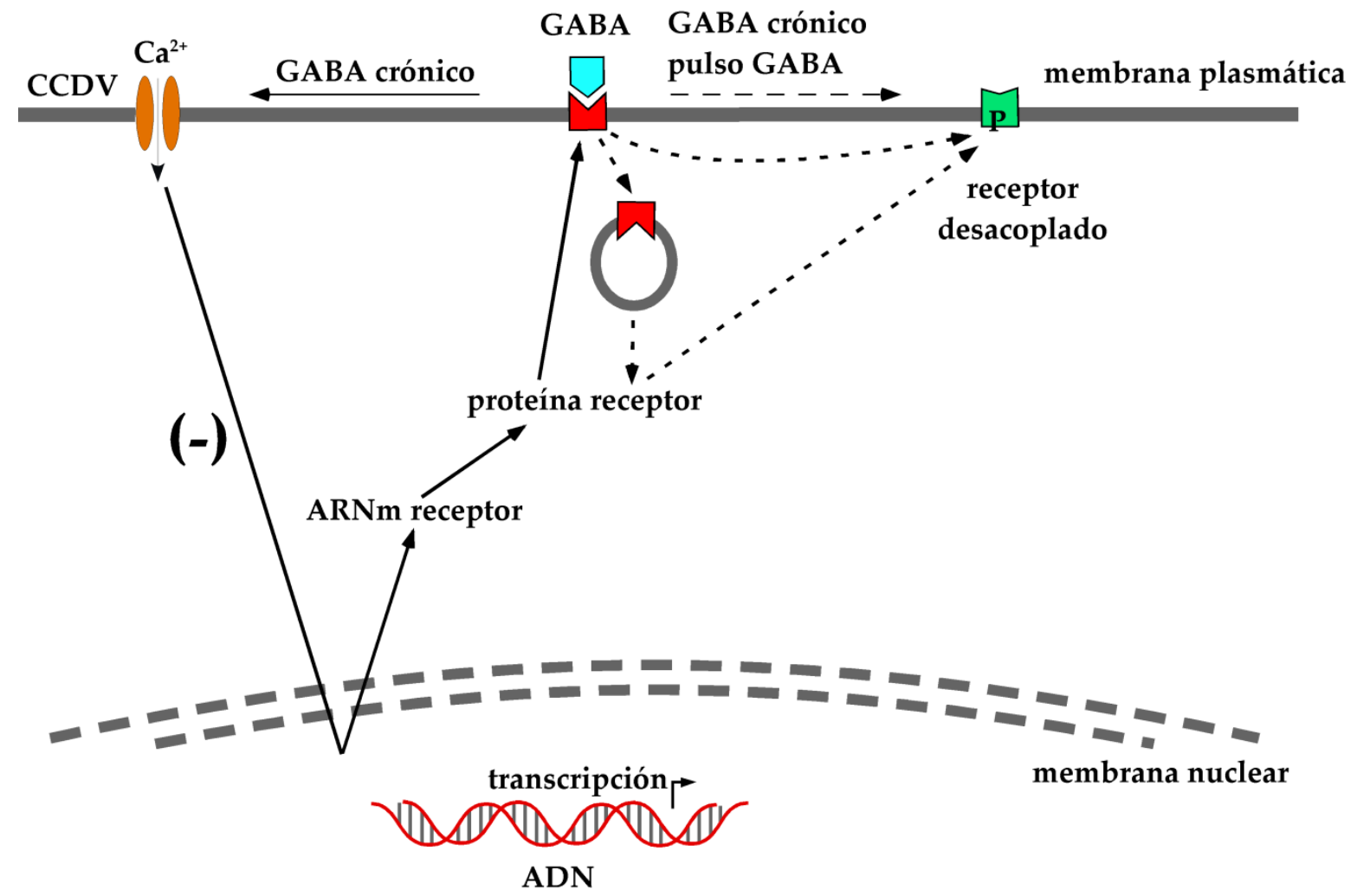

Figura 13: Mecanismo de regulación del receptor $\mathrm{GABA}_{\mathrm{A}}$ inducida por la exposición a GABA. La exposición crónica a GABA induce desacoplamiento y una reducción en la transcripción de las subunidades del receptor $\mathrm{GABA}_{\mathrm{A}}$ vía activación de CCDV. La exposición breve a GABA (pulso) produce sólo desacoplamiento y está acompañada por un cambio en la composición de subunidades del receptor y un aumento en la fosforilación de la subunidad $\gamma 2$.

Aunque la escala de tiempo es mucho más rápida que en experimentos con animales, los cultivos neuronales parecen representar un buen modelo para el estudio de tolerancia a 
la acción de diferentes drogas. La exposición prolongada ( 48 horas) de neuronas en cultivo a moduladores alostéricos positivos del receptor $\mathrm{GABA}_{\mathrm{A}}$, tales como benzodiacepinas, barbitúricos o neuroesteroides, produce desacoplamiento pero sin alteraciones en el número de receptores (Roca, Schiller et al. 1990). Estos resultados podrían sugerir que el desacoplamiento es parte del mecanismo de tolerancia. 
OBJETIVOS E HIPÓTESIS 


\section{Objetivo general:}

Numerosos trabajos han estudiado el efecto de la administración crónica de benzodiacepinas, sin embargo, muy pocos analizan en forma simultánea el desarrollo de tolerancia mediante ensayos conductuales y el mecanismo molecular subyacente.

Ha sido reportado que la administración subcutánea diaria (una inyección por día) de diacepam $(15 \mathrm{mg} / \mathrm{kg})$ en ratas (Sprague-Dawley) induce rápidamente tolerancia a los efectos sedativos mientras que se desarrolla tolerancia a los efectos ansiolíticos luego de un período más prolongado de administraciones con la benzodiacepina (Fernandes, Arnot et al. 1999). El objetivo general del presente proyecto fue dilucidar el mecanismo molecular de la tolerancia a los efectos farmacológicos de las benzodiacepinas utilizando este modelo de administración crónica de diacepam en ratas durante 7 o 14 días. A tal fin, se llevaron a cabo en forma paralela experimentos conductuales para evaluar la tolerancia a los efectos sedativos y ansiolíticos de la benzodiacepina y experimentos bioquímicos para analizar el mecanismo molecular implicado. También se investigaron las bases moleculares de la tolerancia en un modelo ex vivo de cultivos neuronales tratados crónicamente con diacepam.

\section{Hipótesis:}

Se investigó la hipótesis de que el desarrollo de tolerancia a las benzodiacepinas está mediado por diferentes mecanismos adaptivos que alteran la estructura y función del receptor $\mathrm{GABA}_{\mathrm{A}}$, tales como:

1) Disminución en la interacción entre los sitios de unión de GABA y benzodiacepinas:

Diferentes trabajos demostraron que el tratamiento crónico con benzodiacepinas induce el desacoplamiento entre los sitios de unión de GABA y benzodiacepinas, 
sugiriendo que este proceso es responsable de la reducción de la acción de las benzodiacepinas.

2) Cambios en la composición de subunidades a del receptor:

Dado que la acción de las benzodiacepinas depende del subtipo de subunidad $\alpha$ presente en el receptor, es posible que la tolerancia esté mediada por un cambio en el subtipo de esta subunidad.

3) Alteraciones en el grado de fosforilación del receptor:

La acción de distintos moduladores alostéricos del receptor, tales como benzodiacepinas y neuroesteroides, está regulada por cambios en el estado de fosforilación del receptor, por lo tanto, esta modificación post-traduccional podría ser responsable del desarrollo de tolerancia.

Ha sido reportado que la administración crónica de benzodiacepinas estimula las corrientes de calcio mediadas por los CCDV de tipo L. Por consiguiente, se analizó en un modelo ex vivo de cultivos neuronales la hipótesis de que el mecanismo de tolerancia está mediado por la activación de CCDV.

\section{Objetivos específicos:}

A) Analizar el desarrollo de tolerancia a los efectos sedativo y ansiolítico del diacepam luego de tratamientos crónicos de 7 o 14 días mediante experimentos conductuales.

B) Determinar la concentración de diacepam en la corteza cerebral de ratas tratadas en forma aguda o crónica con la benzodiacepina a fin de descartar que la tolerancia esté mediada por alteraciones en factores farmacocinéticos. 
C) Estudiar el efecto de la administración crónica de diacepam sobre el acoplamiento entre los sitios de unión de GABA y benzodiacepinas, mediante ensayos de unión de $\left[{ }^{3} \mathrm{H}\right]$ flunitrazepam $\left(\left[{ }^{3} \mathrm{H}\right] \mathrm{FNZ}\right)$ en una fracción de membranas de corteza cerebral de rata.

D) Determinar el efecto del tratamiento crónico con diacepam sobre la composición de subunidades del receptor $\mathrm{GABA}_{\mathrm{A}}$ en la corteza cerebral de rata. A tal fin, se estudió primero el efecto del tratamiento con la benzodiacepina sobre los niveles totales de ciertas subunidades $\alpha$ del receptor mediante experimentos de PCR cuantitativa en tiempo real y western blot. Luego se investigaron cambios en el porcentaje de los distintos subtipos de receptor mediante ensayos de co-inmunoprecipitación y western blot.

E) Investigar si el tratamiento prolongado con diacepam induce cambios en el estado de fosforilación del receptor $\mathrm{GABA}_{\mathrm{A}}$ en la corteza cerebral de rata, mediante ensayos de western blot.

F) Estudiar el efecto de la exposición prolongada de diacepam sobre la función del receptor $\mathrm{GABA}_{\mathrm{A}}$ en cultivos primarios de corteza cerebral de rata. Primero se analizó el efecto de un tratamiento con diacepam durante 48 horas sobre el acoplamiento entre los sitios de unión de GABA y benzodiacepinas. Posteriormente, se estudió el rol de los CCDV-L sobre el desarrollo de desacoplamiento. 
MATERIALES Y MÉTODOS 


\section{Tratamientos crónicos in vivo con diacepam}

Se utilizaron ratas machos adultas (Sprague-Dawley) con un peso de $250 \mathrm{~g}$ al comienzo de los tratamientos. Estos animales fueron tratados durante 7 o 14 días mediante una inyección diaria subcutánea con diacepam ( $15 \mathrm{mg} / \mathrm{kg}$ peso, $1 \mathrm{ml} / \mathrm{kg}$ peso) o vehículo (aceite de sésamo, control). Este tratamiento está basado en estudios previos de otro grupo de investigación (Fernandes, Arnot et al. 1999). Las inyecciones subcutáneas tienen por objeto producir niveles plasmáticos más estables de diacepam que los producidos por un tratamiento de inyecciones intra-peritoneales. Con el objeto de igualar la manipulación y el número de inyecciones y para realizar los ensayos conductuales el mismo día, todos los animales recibieron un total de 14 inyecciones. Los animales se separaron en cuatro grupos experimentales que recibieron los siguientes tratamientos:

1) Control: 14 días de inyecciones con vehículo.

2) Agudo: 13 días de inyecciones con vehículo y luego 1 día de inyección con diacepam.

3) Crónico 7 días: 7 días de inyecciones con vehículo y luego 7 días de inyecciones con diacepam.

4) Crónico 14 días: 14 días de inyecciones con diacepam.

\section{Ensayos conductuales}

\subsection{Medición del efecto ansiolítico de las benzodiacepinas}

Luego de dos horas de la última inyección, cuando se alcanzó la máxima concentración de diacepam en el cerebro (Fernandes, Arnot et al. 1999), se realizó el test del laberinto en cruz elevado (Elevated plus-maze, EPM), para la medición del efecto ansiolítico de las benzodiacepinas. Dicho test fue realizado en una sala de conducta 
totalmente aislada e insonorizada a una temperatura de $20 \pm 2{ }^{\circ} \mathrm{C}$ y con una intensidad lumínica de 40 lux. El EPM fue construido en madera negra y consta de 2 brazos abiertos opuestos de 40 x $10 \mathrm{~cm}$ y dos brazos cerrados opuestos de las misma medida con paredes de $35 \mathrm{~cm}$ de alto y se dispuso a una altura de $80 \mathrm{~cm}$ con respecto al suelo. Una cámara filmadora fue montada verticalmente por encima del laberinto y el comportamiento fue monitoreado desde un monitor en una sala adyacente. Las ratas fueron colocadas en el centro del laberinto $(10 \times 10 \mathrm{~cm})$ enfrentando un brazo abierto, y se las dejó explorar libremente el laberinto por 5 minutos. Al final de cada prueba el laberinto fue aseado con etanol al 70\%. El número de entradas y el tiempo transcurrido en los brazos abiertos o cerrados, fueron recogidos por el programa Ethovision XT (Noldus). Se calcularon los

porcentajes de entradas a los brazos abiertos y el tiempo de permanencia en los mismos. Un incremento en el porcentaje de entradas y de tiempo en los brazos abiertos son interpretados como una respuesta ansiolítica (Fernandes, Arnot et al. 1999). Además, se determinaron el número total de entradas a los brazos y la distancia total recorrida. No es posible testear el grupo tratado en forma aguda con diacepam pues los animales se caen del laberinto debido al efecto sedativo de la benzodiacepina.

\subsection{Medición del efecto sedativo de las benzodiacepinas}

Para medir el efecto sedativo de las benzodiacepinas fue utilizado el test de campo abierto (Open field, OF) el cual se llevó a cabo a continuación del test en el EPM. El OF fue construido en madera con un tamaño de $1 \mathrm{x} 1 \mathrm{~m}$ y con paredes de $1 \mathrm{~m}$ de altura. El ensayo fue llevado a cabo en la misma sala y bajo las mismas condiciones de temperatura e intensidad lumínica anteriormente mencionadas. Al final de cada prueba el OF fue aseado con etanol al 70\%. Los animales fueron colocados individualmente en una esquina del OF y la actividad locomotora espontánea, medida como la distancia total recorrida, fue estimada durante 20 minutos mediante el programa Ethovision XT (Noldus). Una disminución en la actividad locomotora espontánea es una medida del efecto sedativo de las benzodiacepinas. También se determinó la distancia recorrida en la zona central de la arena $(40$ x $40 \mathrm{~cm})$. Al finalizar los ensayos conductuales los animales fueron sacrificados por decapitación y las cortezas cerebrales disecadas. 


\section{Cuantificación de diacepam en corteza cerebral}

Las determinaciones de diacepam por cromatografía líquida de alta resolución (highperformance liquid chromatography, HPLC) fueron llevadas a cabo en el Laboratorio de Análisis Clínicos y Medicina Nuclear Dr. M. Schere.

Las cortezas cerebrales de los animales tratados con vehículo (basal) o diacepam fueron homogeneizadas en ácido perclórico 0,2 N (7,5 ml/g tejido) en un homogeneizador de vidrio con émbolo de vidrio. Los homogenatos fueron centrifugados a $9.800 \mathrm{~g}$ durante 5 min. Los sedimentos fueron descartados y el pH de los sobrenadantes fue ajustado a 5 con $\mathrm{NaOH} 5 \mathrm{~N}$. Luego de una extracción líquido-líquido con diclorometano, el solvente se evaporó a sequedad y se reconstituyó la muestra en una mezcla de buffer fosfato y acetonitrilo.

Se utilizó un cromatógrafo AGILENT modelo 1100, con inyector automático y detector UV de longitud de onda variable. Se empleó una columna de fase reversa C18. La fase móvil estuvo constituida por una mezcla de buffer fosfato y acetonitrilo. Se utilizó una longitud de onda de $220 \mathrm{~nm}$ para la detección.

Los valores de concentración se calcularon a partir de una curva de calibración donde la concentración es función de la relación entre las áreas de los picos del analito y del estándar interno, clonazepam. La curva de calibración estuvo compuesta por una muestra cero y ocho muestras con las siguientes concentraciones de diacepam: 10, 25, 50, 100, 200, 500,1000 y $5000 \mathrm{ng} / \mathrm{ml}$.

\section{Ensayo de unión de $\left[{ }^{3} H\right] F N Z$}

El tejido fue homogeneizado en 10 volúmenes de 0,32 $\mathrm{M}$ de sacarosa en un homogeneizador de vidrio con émbolo de teflón y centrifugado a $1.000 \mathrm{~g}$ durante 10 minutos. El sobrenadante obtenido fue centrifugado a $27.000 \mathrm{~g}$ durante 30 minutos y el nuevo sobrenadante descartado. Para los experimentos donde se estudió el efecto de un shock osmótico, el sedimento (P2) fue homogeneizado en 10 volúmenes de agua 
bidestilada y centrifugado a $27.000 \mathrm{~g}$ durante 30 minutos. El sedimento (con o sin shock osmótico) fue homogeneizado en un buffer ácido etilendiaminotetraacético (EDTA) $1 \mathrm{mM}$ y fluoruro de fenilmetilsulfonilo (PMSF) $1 \mathrm{mM}$. En el caso de los experimentos con cultivos neuronales (ver preparación en los puntos 9 y 10), al finalizar los tratamientos con diacepam el medio fue aspirado y las células cosechadas con un rastrillo plástico con buffer fosfato salino (PBS). La suspensión fue centrifugada a $500 \mathrm{~g}$ durante 5 minutos y el sedimento fue homogeneizado con buffer EDTA $1 \mathrm{mM}$ y PMSF $1 \mathrm{mM}$. Los homogenatos obtenidos fueron dializados toda la noche contra 1,5 1 de buffer fosfato (4 cambios de buffer). La concentración de proteínas en los homogenatos fue medida por Bradford. Alícuotas de homogenato, conteniendo $100 \mu \mathrm{g}$ de proteína, se incubaron a $0^{\circ} \mathrm{C}$ durante 1 hora en un volumen final de $0,5 \mathrm{ml}$ de PBS conteniendo $\left[{ }^{3} \mathrm{H}\right] \mathrm{FNZ}$ (Perkin Elmer Life Sciences) 0,01 a $20 \mathrm{nM}$ en experimentos de saturación de la unión de benzodiacepinas. Para medir la potenciación de la unión de benzodiacepinas por GABA, $\left[{ }^{3} \mathrm{H}\right] \mathrm{FNZ} 0,5 \mathrm{nM}$ fue utilizado solo o en presencia de GABA $1 \mathrm{mM}$. La unión inespecífica fue determinada en presencia de diacepam $100 \mu \mathrm{M}$. La reacción se detuvo agregando $3 \mathrm{ml}$ de PBS frío y filtrando inmediatamente la suspensión con vacío a través de filtros de fibra de vidrio (Whatman GF/B). Los filtros se lavaron 2 veces con $3 \mathrm{ml} \mathrm{de} \mathrm{PBS} \mathrm{frío} \mathrm{y} \mathrm{la} \mathrm{radioactividad}$ retenida en los mismos se cuantificó mediante un contador de centelleo líquido en líquido de centelleo Optiphase Hisafe 2 (Perkin Elmer Life Sciences). Los datos del ensayo de saturación de la unión de $\left[{ }^{3} \mathrm{H}\right] \mathrm{FNZ}$ fueron analizados por medio de regresión no lineal. El acoplamiento representa el grado de interacción entre los sitios de unión de GABA y benzodiacepinas y se lo estimó como porcentaje de la potenciación de la unión de $\left[{ }^{3} \mathrm{H}\right] \mathrm{FNZ}$ por GABA, con respecto al control (tratamiento con vehículo). Se lo calculó como: (\% potenciación tratado / \% potenciación control) x 100. El desacoplamiento se lo calculó como: [1 - (\% potenciación tratado / \% potenciación control)] x 100 (Gravielle, Faris et al. 2005).

\section{PCR cuantitativa en tiempo real}

El ARN total fue extraído a partir de las cortezas cerebrales de rata utilizando un kit comercial (RNeasy midi kit, Qiagen). Los cebadores (Tecnolab) y la sonda (TaqMan, 
Applied Biosystem) para la amplificación de las subunidades $\alpha 1, \alpha 3$ y $\alpha 5$ fueron diseñados utilizando el programa Primer Express (Applied Biosystem). La sonda y los cebadores para amplificar el ARN ribosomal (ARNr) 18S fueron comprados a Applied Biosystem. Las secuencias de los cebadores fueron: a1, 5'-CCCCGGCTTGGCAACTAT-3' y 5'TGTCTCAGGCTTGACTTCTTTCG-3'; $\alpha 3$, 5'-CACCATGACCACCTTGAGTATCA-3' y 5'- CCGTCGCGTATGCCACTT-3'; $\alpha 5,5^{\prime}$-CAACATCACAATATTCACCAGGATCT3' y 5'-CCCAGG CCGCAGTCTGT-3'. La secuencia de las sondas fueron: $\alpha 1$, 5'TAAAAGTGCGACCATAGAA-3'; $\quad \alpha 3, \quad 5^{\prime}$-TGCCAGAAACTCTTTAC-3'; $\alpha 5, \quad 5^{\prime}$ CTCTTGGATGGCTATGAC-3'. Estas secuencias fueron diseñadas para amplificar la región que codifica para el bucle citoplasmático ubicados entre los dominios TM3 y TM4, un área con una secuencia de aminoácidos diferentes entre los distintos tipos de subunidades del receptor. Se utilizó un ensayo de PCR cuantitativa de un solo paso utilizando una mezcla enzimática comercial (AgPathID ${ }^{\mathrm{TM}}$ one-step RT PCR kit, Ambion). El equipo empleado para los ensayos fue el modelo 7500 de Applied Biosystem. La curva estándar para la cuantificación relativa se realizó utilizando un rango de concentraciones de 0,1 a $4 \mathrm{ng} / \mu$ lde ARN total aislado de cortezas controles tratadas con vehículo (Fig. 14). Cada reacción fue realizada por triplicado en un volumen total de $25 \mu 1$ conteniendo: la sonda para la subunidad $\alpha 1, \alpha 3$ o $\alpha 5(250 \mathrm{nM})$, cebadores para las subunidades $\alpha 1, \alpha 3$ o $\alpha 5$ (900 $\mathrm{nM})$, sonda para el ARNr de $18 \mathrm{~S}(50 \mathrm{mM})$ y cebadores para el ARNr $18 \mathrm{~S}(50 \mathrm{nM})$. Las condiciones de incubación fueron: $45^{\circ} \mathrm{C}$ durante 10 minutos, $95^{\circ} \mathrm{C}$ durante 10 minutos seguidos por 50 ciclos de $95^{\circ} \mathrm{C}$ durante 15 segundos y $60^{\circ} \mathrm{C}$ durante 45 segundos. La cantidad relativa de ARN de las subunidades $\alpha 1, \alpha 3$ y $\alpha 5$ fue normalizada con respecto a la cantidad relativa del ARNr 18S (control interno) (Gravielle, Faris et al. 2005). 
A

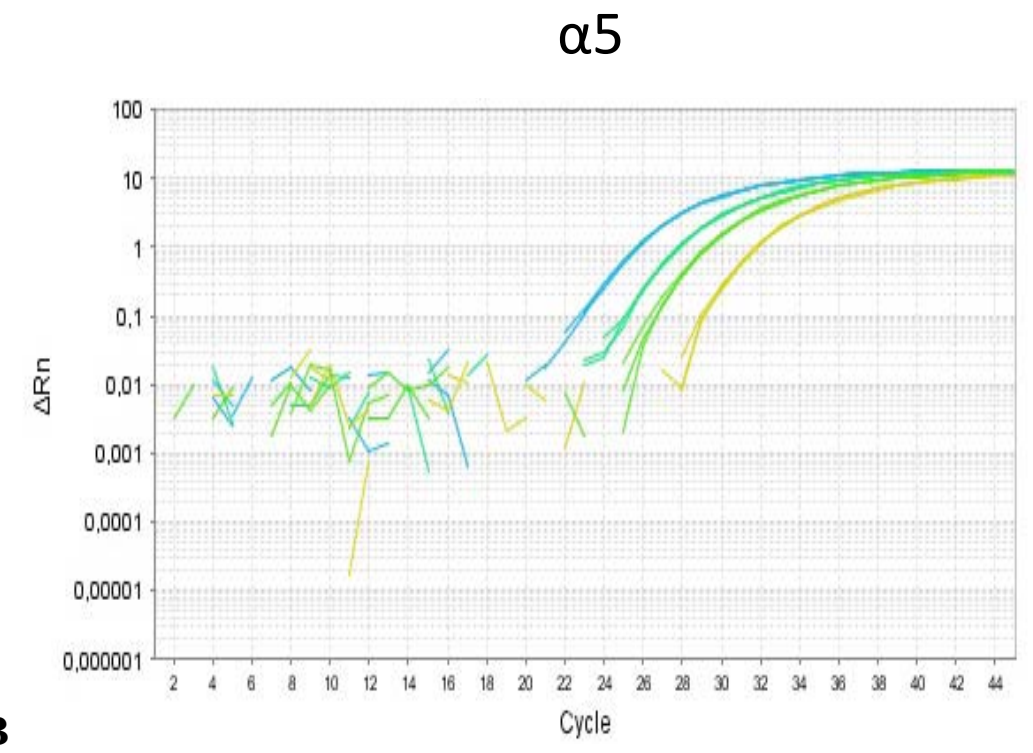

ARNr $18 \mathrm{~S}$

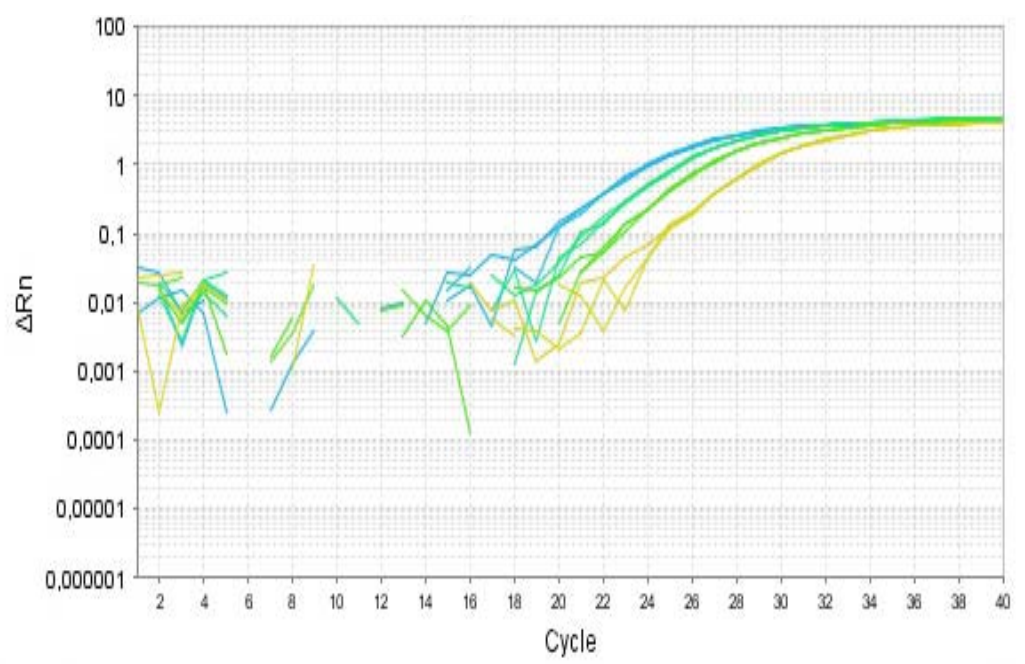




\section{C}

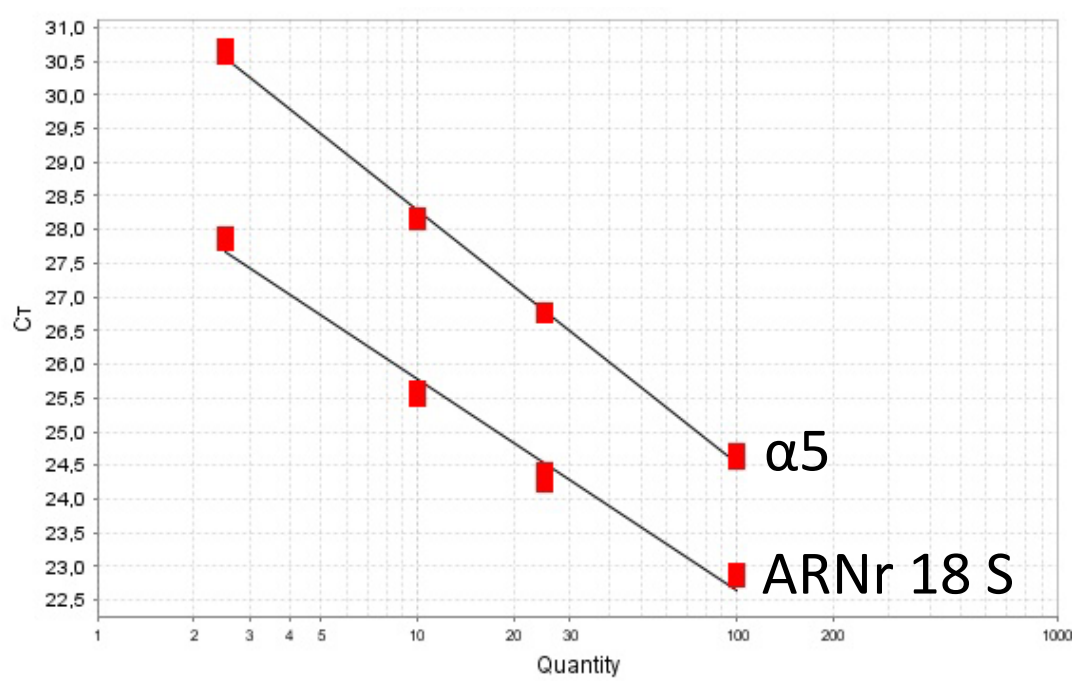

Figura 14: Experimento representativo de PCR cuantitativa en tiempo real. A) y B) Gráficos de amplificación utilizados para generar las curvas estándares. Se representa la magnitud de la fluorescencia normalizada con respecto a la referencia pasiva, en función del número de ciclo. C) Curva estándar. Se representa el ciclo umbral $(\mathrm{Ct})$ en función de la cantidad inicial relativa de ARN total.

\section{Cuantificación de la subunidad $\alpha 1$ total del receptor $\mathrm{GABA}_{\mathrm{A}}$ por western blotting.}

La fracción de membrana $\mathrm{P}_{2}$ fue obtenida como se mencionó en el punto 4 pero en este caso el sedimento fue homogeneizado en buffer de ensayo de radioinmunoprecipitación (RIPA) conteniendo $50 \mathrm{mM}$ Tris $\mathrm{pH}$ 7,4,1 mM de EDTA, 150 $\mathrm{mM}$ de $\mathrm{NaCl}, 3 \%$ Triton $\mathrm{X}-100.0,1 \%$ dodecil sulfato de sodio (SDS), 0,5\% de deoxicolato de sodio y una mezcla de inhibidores de proteasas (Complete EDTA-free, Roche), incubado a $4^{\circ} \mathrm{C}$ con rotación vertical durante 30 minutos y centrifugado a $27.000 \mathrm{~g}$ por 30 minutos. El sedimento obtenido fue descartado. Se midió la concentración de proteínas del sobrenadante por el método de Bradford y la muestra (30 $\mu \mathrm{g}$ de proteína) fue resuspendida en buffer de siembra conteniendo $5 \%$ de $\beta$-mercaptoetanol (volumen total 30 $\mu \mathrm{l}$ ), calentada durante 5 minutos a $95^{\circ} \mathrm{C}$ y centrifugada por 5 minutos a $2.000 \mathrm{~g}$. 
Las proteínas del sobrenadante fueron separadas en geles de acrilamida $10 \%$ desnaturalizante $(125 \mathrm{mV})$ y transferidas a una membrana de nitrocelulosa $(25 \mathrm{mV}$ durante 2 horas). Las membranas fueron bloqueada durante 2 horas con leche descremada $5 \%$ en buffer Tris salino $20 \mathrm{mM}$ (TBS) conteniendo 0,1\% de Tween-20. Las membranas fueron luego incubadas durante toda la noche a $4^{\circ} \mathrm{C}$, con un anticuerpo de conejo (Santa Cruz) que reconoce la subunidad $\alpha 1$ del receptor $\mathrm{GABA}_{\mathrm{A}}$, utilizado en una dilución 1:250. Las señales fueron detectadas incubando la membrana durante $1,5 \mathrm{hs}$ a temperatura ambiente con agitación, con un anticuerpo secundario anti IgG de conejo (Santa Cruz, dilución 1:2.000) acoplado a peroxidasa de rábano, mediante quimioluminiscencia (ECL detection kit, Pierce). Las membranas fueron sometidas a un tratamiento de desnudamiento ácido (stripping) con una solución de glicina $1 \mathrm{M}$ y $\operatorname{SDS} 2 \% \mathrm{pH} 2,5$, e incubadas, durante toda la noche a $4^{\circ} \mathrm{C}$, con un anticuerpo de conejo (dilución 1:500) que reconoce a actina (Sigma). Posteriormente, las membranas fueron incubadas con un anticuerpo secundario anti IgG de conejo acoplado a peroxidasa de rábano (1,5 horas a temperatura ambiente, dilución 1:2.000). La señal de actina fue detectada también por quimioluminiscencia. La señal inmunorreactiva de $\alpha 1$ fue normalizada con respecto a la señal de actina.

\section{Inmunoprecipitación del receptor $\mathrm{GABA}_{\mathrm{A}} \mathrm{y}$ ensayo de western blot}

El sedimento de la fracción de membrana $\mathrm{P}_{2}$ fue homogeneizado en un buffer deoxicolato conteniendo Tris- $\mathrm{HCl} 10 \mathrm{mM} \mathrm{pH} \mathrm{8,5,} \mathrm{NaCl} 150 \mathrm{mM}$, deoxicolato de sodio 0,5 $\%$, fosfatidilcolina $0,05 \%$, EDTA $1 \mathrm{mM}$, PMSF $1 \mathrm{mM}$ e incubado por 20 minutos con rotación vertical a $4^{\circ} \mathrm{C}$. Este buffer de lisis mantiene unidas las subunidades del receptor. Luego de esta incubación el homogenato fue centrifugado a $27.000 \mathrm{~g}$ por 30 minutos a $4^{\circ} \mathrm{Cy}$ el sedimento se descartó (Jechlinger, Pelz et al. 1998). Se midió la concentración de proteínas del sobrenadante por el método de Bradford y se diluyó este lisado con buffer deoxicolato hasta obtener una concentración de $1 \mathrm{mg}$ de proteína $/ \mathrm{ml}$. Con el objeto de reducir el efecto de la unión inespecífica de la proteína A-agarosa a proteínas del lisado, se realizó un paso de pre-aclaramiento mediante incubación de $500 \mu 1$ de este lisado con $20 \mu 1$ de proteína A-agarosa (Santa Cruz) durante 40 minutos a $4^{\circ} \mathrm{C}$ con agitación. Luego se centrifugó el lisado durante 5 minutos a $2.000 \mathrm{~g}$ y el sobrenadante fue incubado durante 
toda la noche a $4^{\circ} \mathrm{C}$ con rotación vertical con $2 \mu \mathrm{g}$ de un anticuerpo de conejo (Alpha Diagnostic) que reconoce la subunidad $\gamma 2$ del receptor $\mathrm{GABA}_{\mathrm{A}}$. Los inmunocomplejos fueron precipitados adicionando $20 \mu \mathrm{l}$ de proteína A-agarosa e incubados durante toda la noche a $4^{\circ} \mathrm{C}$ con rotación. Las esferas de agarosa unidas al inmunocomplejo fueron precipitadas mediante centrifugación $\left(5\right.$ minutos a $\left.2.000 \mathrm{~g}, 4^{\circ} \mathrm{C}\right)$. Los sedimentos fueron lavados 3 veces con $500 \mu \mathrm{l}$ de buffer deoxicolato mediante resuspensión seguida de centrifugación (Ravindran and Ticku 2006). El sedimento final fue resuspendido en $25 \mu 1$ de buffer de siembra conteniendo $5 \%$ de $\beta$-mercaptoetanol y calentado por 5 minutos a $95^{\circ} \mathrm{C}$ para separar el inmunocomplejo de las esferas de agarosa y disociar las subunidades del receptor. Las proteínas fueron separadas en un gel de poliacrilamida desnaturalizante y transferidas a membranas de nitrocelulosa de la misma forma que en el punto 6. Luego del bloqueo, las membranas fueron incubadas con anticuerpos de cabra que reconocen la subunidad $\alpha 1, \alpha 3$ o $\alpha 5$ del receptor GABA $_{A}$ (Santa Cruz), diluidos 1:200 en solución de bloqueo durante toda la noche a $4{ }^{\circ} \mathrm{C}$ con agitación. Luego se incubaron con un anticuerpo anti IgG de cabra (Santa Cruz), diluido 1:2.000 en solución de bloqueo, conjugado a la enzima peroxidasa de rábano durante 1,5 horas a temperatura ambiente con agitación. La señal inmunorreactiva fue detectada por quimioluminiscencia. Luego de un proceso de desnudamiento ácido las membranas fueron incubadas con un anticuerpo anti IgG de conejo acoplado a peroxidasa de rábano (Santa Cruz, dilución 1:4.000 en solución de bloqueo) durante 1,5 horas a temperatura ambiente y la señal fue detectada por quimioluminiscencia. Las bandas correspondientes a las diferentes subunidades fueron normalizadas con respecto a la señal del anticuerpo anti $\gamma 2$ utilizado para inmunoprecipitar al receptor. Se realizaron experimentos controles (controles negativos) en ausencia del anticuerpo anti subunidad $\gamma 2$ del receptor $\mathrm{GABA}_{\mathrm{A}}$, para verificar la especificidad de la inmunoprecipitación, descartando la unión inespecífica de las subunidades del receptor a las esferas de proteína A-agarosa.

\section{Ensayo de fosforilación de la subunidad $\gamma 2$ del receptor $\mathrm{GABA}_{\mathrm{A}}$}

El sedimento de la fracción de membranas $\mathrm{P}_{2}$ fue resuspendido en buffer HEPES conteniendo $\mathrm{NaCl}$ 0,3 $\mathrm{N}, \mathrm{MgCl}_{2}$ 1,5 mM, EDTA 0,2 mM, TritonX-100 0,1\%, $\beta$ - 
glicerofosfato $0,5 \mathrm{mM}$, metavanadato de sodio $0,1 \mathrm{mM}, 0,8 \mathrm{mM}$ DTT y $1 \mathrm{mM}$ PMSF e incubado durante 20 minutos con rotación vertical a $4{ }^{\circ} \mathrm{C}$. El lisado fue centrifugado a $27.000 \mathrm{~g}$ por 30 minutos a $4^{\circ} \mathrm{C}$ y el sedimento final se descartó. Se midió la concentración de proteínas en el sobrenadante por el método de Bradford. La muestra final (30 $\mu \mathrm{g}$ de proteína) fue resuspendida en buffer de siembra (volumen final $35 \mu \mathrm{l}$ ) y calentada durante 5 minutos a $95^{\circ} \mathrm{C}$. Las proteínas fueron separadas en un gel de acrilamida desnaturalizante y transferidas a membranas de nitrocelulosa como se describió previamente. Las membranas de nitrocelulosa fueron incubadas durante toda la noche con un anticuerpo de conejo que reconoce a la forma fosforilada de la subunidad $\gamma 2$ del receptor (serina 327) (Abcam, dilución 1:250). Las señales inmunorreactivas fueron reveladas por quimioluminiscencia utilizando un anticuerpo secundario anti $\operatorname{IgG}$ de conejo acoplado a peroxidasa de rábano (Santa Cruz, incubación 1,5 horas, dilución 1:1.000). Para la normalización de los

resultados, las membranas fueron sometidas a un tratamiento de desnudamiento ácido e incubadas con un anticuerpo que reconoce la subunidad $\gamma 2$ total (fosforilada y no fosforilada) del receptor (Millipore, dilución 1:500). Las señales fueron reveladas por quimioluminiscencia utilizando un anticuerpo secundario anti IgG de conejo acoplado a peroxidasa de rábano (Santa Cruz, incubación 1,5 horas, dilución 1:1.000) .

\section{Cultivos primarios}

Cultivos primarios neuronales de corteza cerebral de rata (Sprague-Dawley) fueron preparados a partir de embriones de 18 días de gestación (Gravielle, Faris et al. 2005). Los cerebros totales fueron removidos, las cortezas cerebrales fueron disecadas bajo lupa y colocadas en solución Hank's fría. El tejido fue cortado con tijeras, triturado con una pipeta serológica de $5 \mathrm{ml}$ y centrifugado durante 5 minutos a $500 \mathrm{~g}$. El sedimento resultante fue resuspendido en $5 \mathrm{ml}$ de medio de plaqueo (medio Neurobasal ${ }^{\mathrm{TM}}$ más $10 \%$ suero fetal bovino, 100 unidades $/ \mathrm{ml}$ de penicilina, $0,1 \mathrm{mg} / \mathrm{ml}$ de estreptomicina y $2 \mathrm{mM}$ de glutamina, Invitrogen) y triturado nuevamente con pipeta. La suspensión fue agregada al volumen final de medio de plaqueo y se sembró en placas de $100 \mathrm{~mm}$ (Nunc) con una cubierta de poli-Llisina $(0,1 \mathrm{mg} / \mathrm{ml}$, Sigma) a una densidad de 0,75 cortezas por placa. Los cultivos fueron 
incubados durante una hora a $37^{\circ} \mathrm{C}$ en $5 \% \mathrm{CO}_{2}$ y luego el medio fue aspirado y reemplazado con medio libre de suero conteniendo suplemento B27 (Invitrogen).

\section{Tratamientos crónicos ex vivo con diacepam:}

Luego de una semana de incubación los cultivos fueron tratados con vehículo (control), diacepam (50 $\mu \mathrm{M}$ final), flumacenil (50 $\mu \mathrm{M}$ final), flumacenil más diacepam, nifedipina (10 $\mu \mathrm{M}$ final), nifedipina más diacepam, picrotoxina (100 $\mu \mathrm{M}$ final) o diacepam más picrotoxina durante 48 horas.

Las soluciones stocks de estas drogas fueron preparadas con dimetilsulfóxido (DMSO). La concentración final de DMSO en el medio de cultivo fue de 0,5\%.

\section{Análisis de datos}

\subsection{Western blotting}

Para la cuantificación de las bandas obtenidas se utilizó el programa Image J del National Institute of Health (NIH). Se utilizó la herramienta para medir densidad óptica de geles, estableciendo una región de interés rectangular.

\subsection{Análisis estadístico}

Los datos obtenidos fueron analizados utilizando el programa Prism 5.00 para Windows (Graph Pad Software). En todos los casos un valor de $p<0,05$ se consideró estadísticamente significativo.

Los datos fueron analizados mediante la prueba de $t$ de Student de una solo muestra y por medio del Análisis de la Varianza (ANOVA) de una vía, según corresponda. 
RESULTADOS 


\section{Desarrollo de tolerancia a los efectos ansiolíticos y sedativos del diacepam}

Con el objeto de investigar el efecto del tratamiento crónico con benzodiacepinas sobre las acciones sedativas y ansiolíticas del diacepam, ratas macho Sprague-Dawley fueron tratadas con inyecciones subcutáneas diarias de vehículo o diacepam $(15 \mathrm{mg} / \mathrm{kg}$, una inyección diaria) durante 1 (agudo), 7 o 14 días. Con el objeto de verificar el desarrollo de tolerancia a los efectos ansiolíticos y sedativos del diacepam se estudió el efecto de estos tratamientos mediante ensayos conductuales 2 horas luego de la última inyección, momento al cual se detectó el pico de máxima concentración de diacepam (Fernandes, Arnot et al. 1999).

El efecto ansiolítico del diacepam se estimó en el ensayo del EPM. Se registraron tanto el número de entradas como el tiempo de permanencia en los brazos abiertos del laberinto (Fig. 15).

A

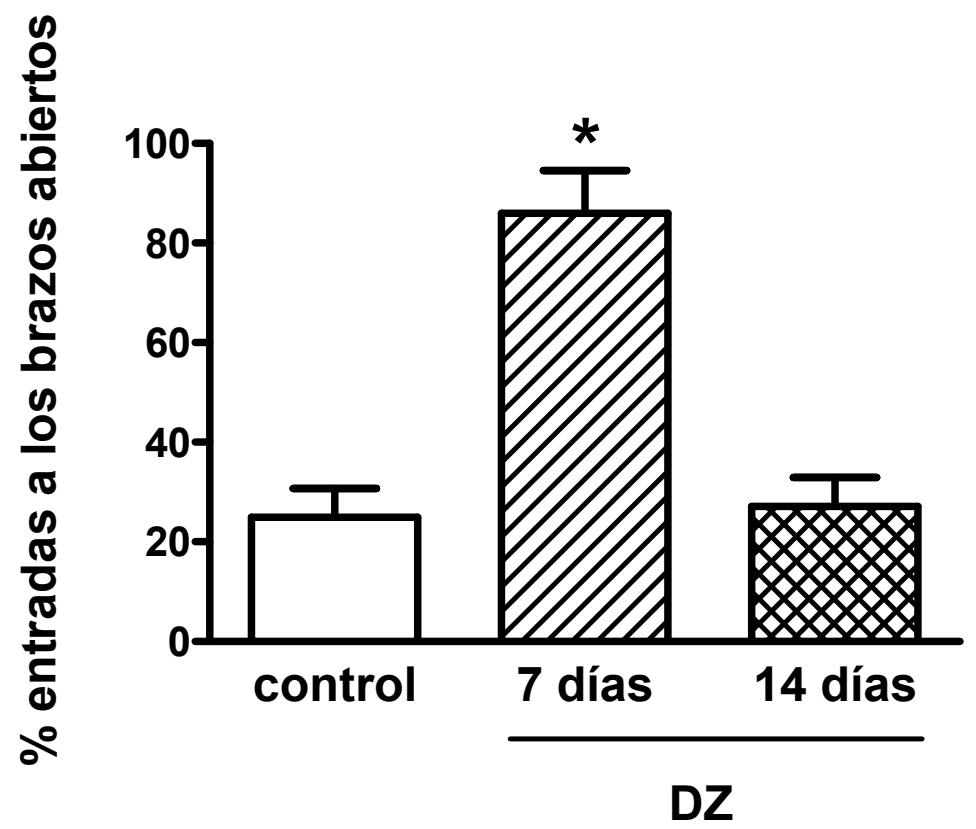




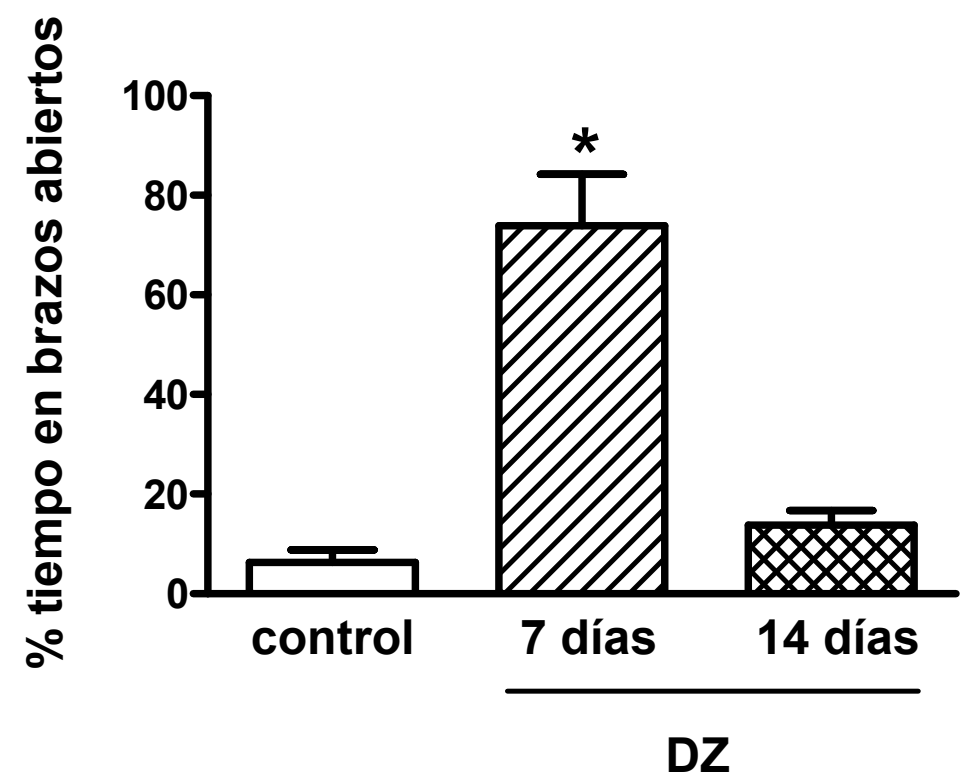

C

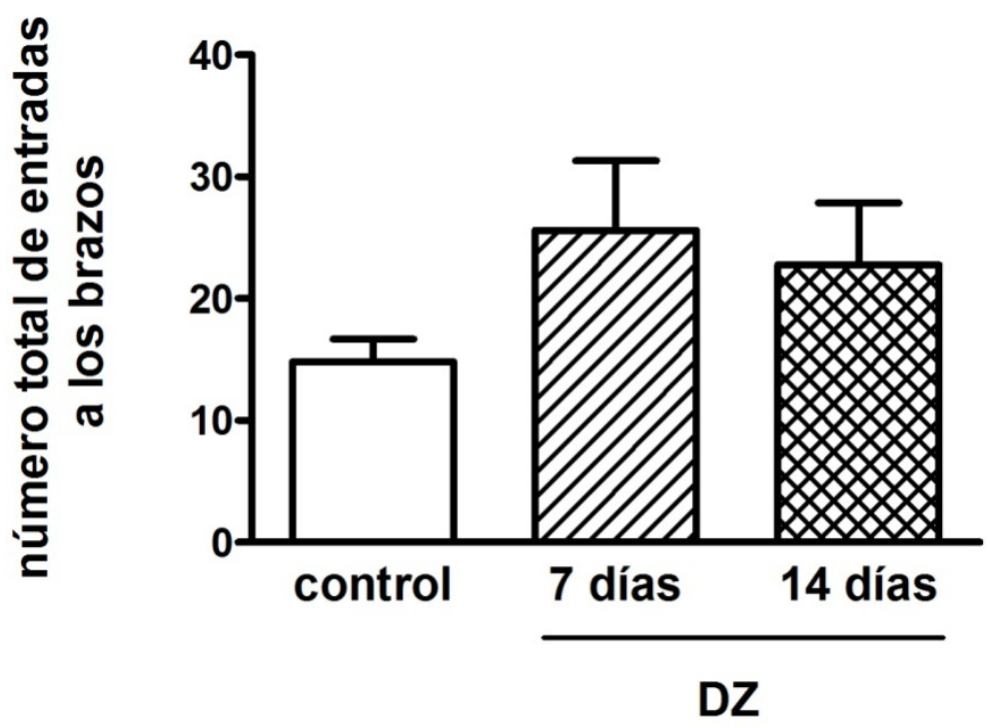




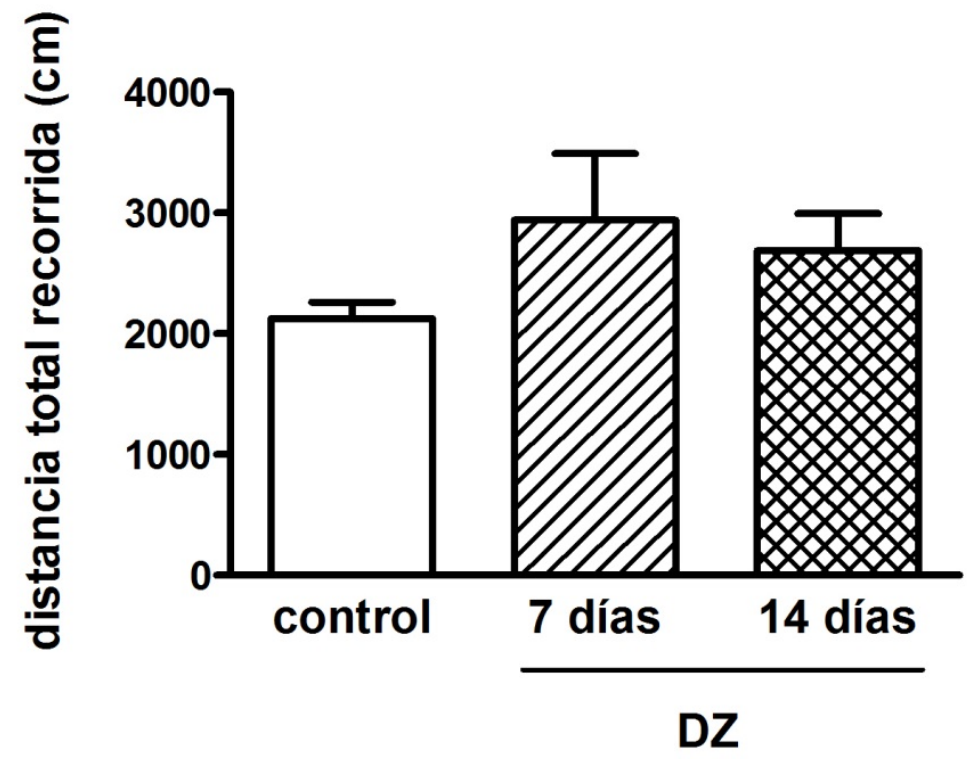

Figura 15: Laberinto en cruz elevado Los animales fueron tratados con vehículo (control) o diacepam (DZ) durante 7 o 14 días. Los resultados se expresan como: A número de entradas en los brazos abiertos (porcentaje con respecto al total de entradas en los brazos), B tiempo de permanencia en los brazos abiertos (porcentaje con respecto al tiempo total en los brazos), C número total de entradas en los dos brazos y D distancia total recorrida en el EPM. Los datos representan las medias \pm SEM de 15 determinaciones independientes. * Significativamente diferente del control, $\mathrm{p}<0,05$ (ANOVA de una vía y test de Dunnett).

El efecto ansiolítico del diacepam se observó luego del tratamiento crónico de 7 días con diacepam como un aumento tanto en el número de entradas como en el tiempo de permanencia en los brazos abiertos del laberinto (Fig. 15 A y B). Sin embargo, este efecto no se manifestó luego de 14 días de tratamiento crónico con diacepam. Estos resultados demuestran que la tolerancia al efecto ansiolítico de esta benzodiacepina se detecta en nuestro protocolo experimental luego de 14 días de tratamiento crónico. El número total de entradas en los brazos del laberinto y la distancia total recorrida no se alteraron luego de los 
tratamientos con diacepam en relación al grupo control (Fig. $15 \mathrm{C} \mathrm{y} \mathrm{D),} \mathrm{sugiriendo} \mathrm{la}$ ausencia de efectos sedativos probablemente debido al desarrollo de tolerancia.

El efecto sedativo del diacepam se midió como una disminución en la actividad locomotora espontánea de la rata en el test de OF registrándose la distancia total recorrida (Fig. 16 A).

A

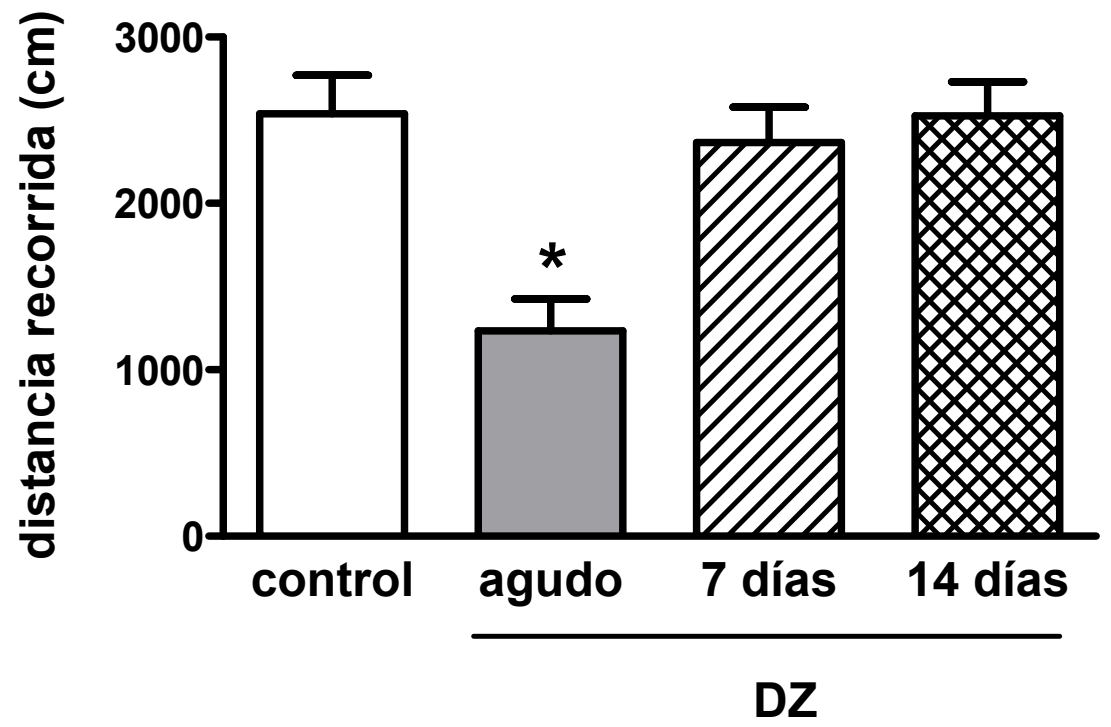




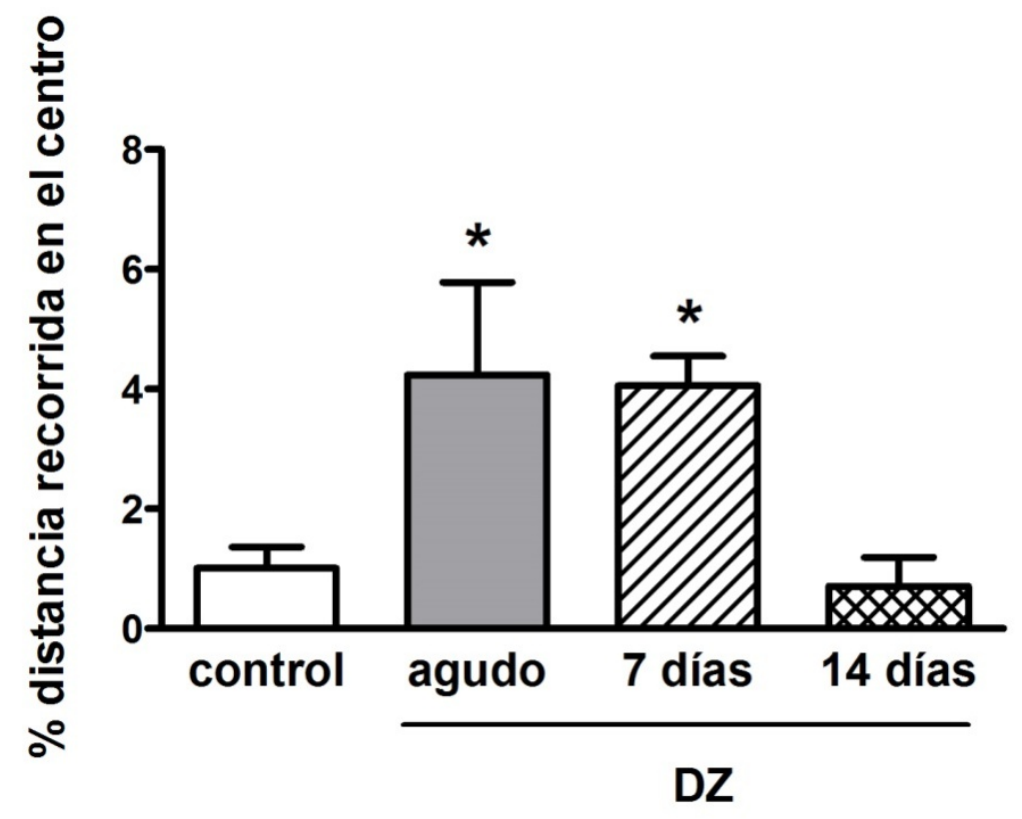

Figura 16: Test de campo abierto. Los animales fueron tratados en forma aguda o crónica durante 7 o 14 días con diacepam (DZ) o vehículo (control). Los resultados se expresan como distancia total recorrida (A) o como la distancia recorrida en el centro del OF (porcentaje con respecto a la distancia total, B). Los datos representan las medias \pm SEM de 15 determinaciones independientes. * Significativamente diferente del control, $\mathrm{p}<0,05$ (ANOVA de una vía y test de Dunnett).

Los animales que recibieron una única dosis de diacepam (agudo) mostraron un clásico efecto sedativo mientras que este efecto no se observó luego de los tratamientos crónicos con diacepam de 7 o 14 días (Fig. 16 A). Estos resultados indican que la tolerancia a los efectos sedativos del diacepam se manifestó en a partir de los 7 días de tratamiento con la benzodiacepina.

El test de OF es también usualmente utilizado para medir efectos ansiolíticos o ansiogénicos. Nuestros resultados muestran un aumento en la distancia recorrida en la zona central del campo abierto luego de los tratamientos agudos y de 7 días con diacepam en 
relación al grupo control, sugiriendo un efecto ansiolítico (Fig. 16 B). La ausencia de efecto ansiolítico luego del tratamiento de 14 días con diacepam demuestra nuevamente el desarrollo de tolerancia.

Por lo tanto, en los experimentos siguientes se emplearon estos tratamientos crónicos con diacepam para estudiar el mecanismo molecular de tolerancia a los efectos ansiolíticos y sedativos de las benzodiacepinas.

\section{Concentraciones de diacepam en la corteza cerebral de ratas}

Es posible que la tolerancia a los efectos farmacológicos de las benzodiacepinas sea la consecuencia de cambios en la absorción, distribución, metabolismo o excreción de la droga resultando en una menor concentración de la misma en los sitios efectores. Sin embargo, existen evidencias que sugieren que factores farmacocinéticos no poseen un rol importante en el desarrollo de tolerancia a las benzodiacepinas (Cowley, Roy-Byrne et al. 1995; Fernandes, File et al. 1996). Con el objeto de investigar la posibilidad de que

cambios en estos factores sean parte del mecanismo de la tolerancia, se determinó la concentración de diacepam en las cortezas cerebrales de ratas tratadas en forma aguda o crónica con diacepam (Fig. 17). 


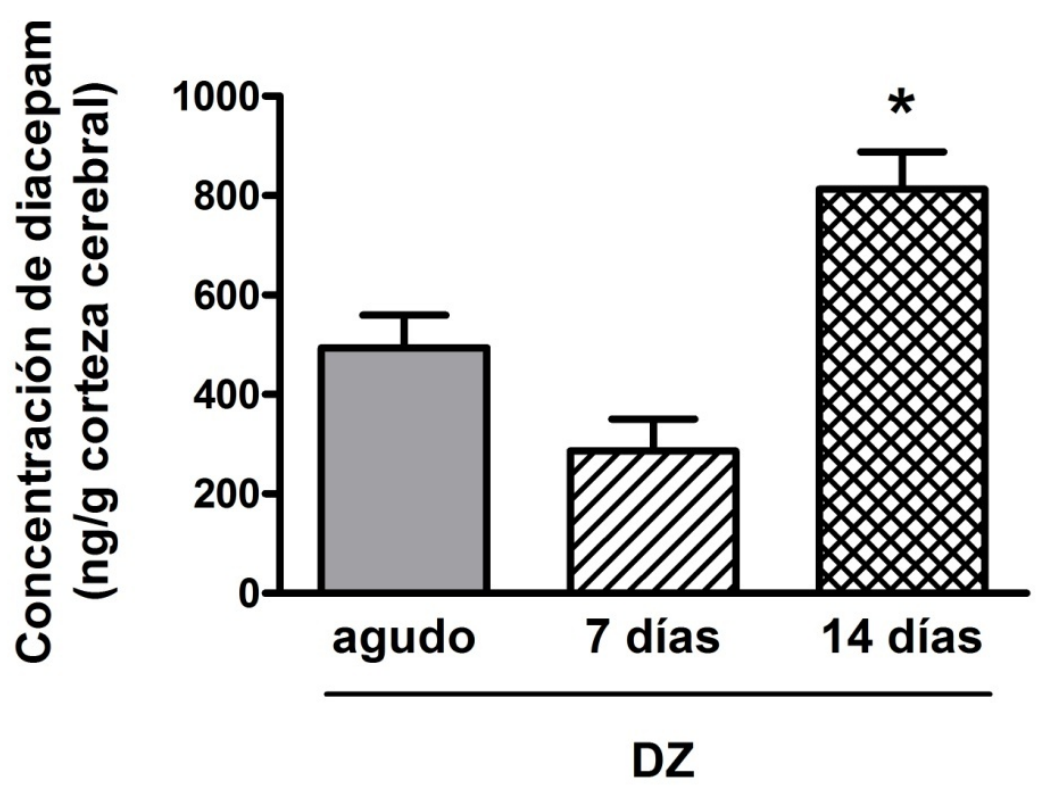

Figura 17: Concentración de diacepam en corteza cerebral. Los animales fueron tratados en forma aguda o crónica durante 7 o 14 días con diacepam (DZ) o vehículo. Los resultados se expresan como concentración de diacepam en $\mathrm{ng} / \mathrm{g}$ de tejido. Los datos representan las medias \pm SEM de 3 determinaciones independientes. * Significativamente diferente del agudo y 7 días, $\mathrm{p}<0,05$ (ANOVA de una vía y test de Tukey).

Los resultados indican que la concentración de diacepam en la corteza cerebral fue similar en animales tratados en forma aguda y durante 7 días con la benzodiacepina. Sin embargo, el tratamiento de 14 días con diacepam resultó en una acumulación significativa de la droga en la corteza cerebral. De este modo, se descartaría que la tolerancia se deba a una disminución en la concentración de benzodiacepinas en esa región del cerebro.

\section{Efecto de la administración crónica de diacepam sobre la interacción entre los sitios de unión de GABA y benzodiacepinas del receptor $\mathrm{GABA}_{\mathrm{A}}$}

Ha sido reportado que la exposición crónica a benzodiacepinas induce una reducción en la interacción alostérica entre los sitios de unión de GABA y benzodiacepinas del 
receptor $\mathrm{GABA}_{\mathrm{A}}$, fenómeno llamado desacoplamiento (Gallager, Lakoski et al. 1984; Marley and Gallager 1989; Roca, Schiller et al. 1990). El desacoplamiento ha sido detectado como una disminución en la potenciación de las acciones del GABA por benzodiacepinas o como una reducción en la estimulación de la unión de benzodiacepinas por GABA. Sin embargo, no se han realizado hasta la fecha estudios donde se analice el desarrollo de tolerancia a las benzodiacepinas en forma paralela con la investigación de la ocurrencia de desacoplamiento.

Con el objeto de determinar si la tolerancia a los efectos sedativos y/o ansiolíticos del diacepam está asociada a un cambio en el acoplamiento entre los sitios de unión de GABA y benzodiacepinas, se estudió el efecto de los tratamientos crónicos de 7 y 14 días con diacepam sobre la estimulación de la unión de $\left[{ }^{3} \mathrm{H}\right] \mathrm{FNZ}$ por GABA en homogenatos de corteza cerebral de rata (Fig. 18).

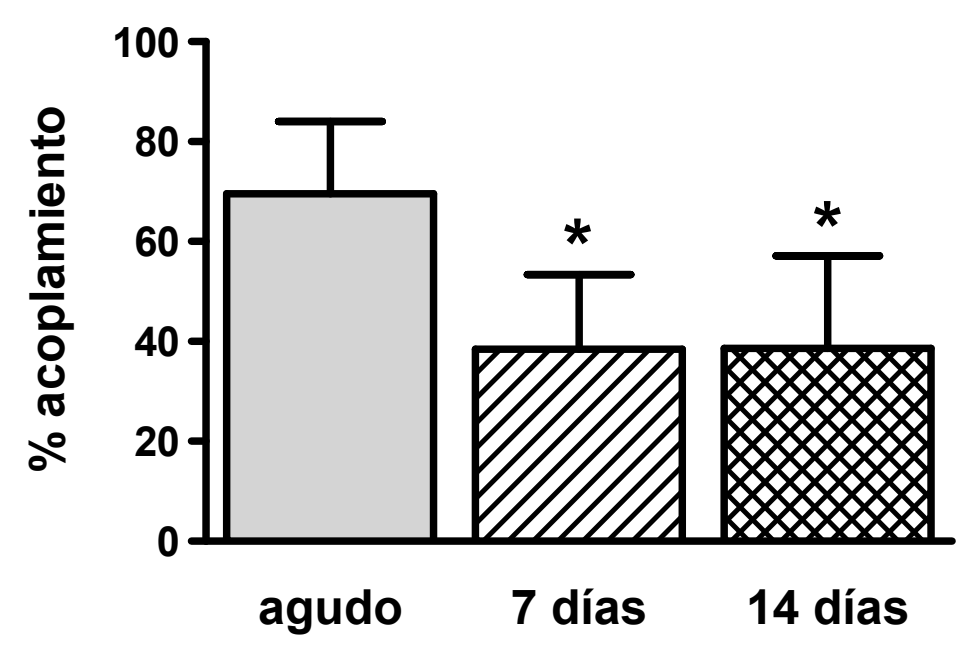

\section{$\mathbf{D Z}$}

Figura 18: Efecto de la administración con diacepam sobre el grado de acoplamiento entre los sitios de unión de GABA y benzodiacepinas. Los animales fueron tratados en forma aguda o crónica durante 7 o 14 días con diacepam (DZ). Los resultados se expresan como porcentaje de acoplamiento con respecto al control (tratamiento con vehículo, $100 \%$ ). Los datos representan las 
medias \pm SEM de 3 a 6 determinaciones independientes. * Significativamente diferente de 100, $\mathrm{p}<0,05$ (test $t$ de Student de una sola muestra).

El tratamiento de 7 días con diacepam indujo una reducción significativa en la potenciación de la unión de FNZ por GABA, equivalente a un $60 \%$ de desacoplamiento, que persistió luego del tratamiento de 14 días. Con el propósito de comprobar que el desacoplamiento está asociado a los tratamientos crónicos, se llevaron a cabo experimentos controles donde se estudió el efecto de una única inyección de diacepam (agudo). Los resultados de estos experimentos indican que este tratamiento no produjo un desacoplamiento significativo.

En ensayos de saturación de la unión de FNZ demostramos que ninguno de los dos tratamientos con diacepam produjo un cambio en el número o afinidad de los sitios de unión (Tabla I). 
Tabla I. La exposición crónica con diacepam no tiene efecto sobre la unión de $\left[{ }^{3} H\right] F N Z$

\author{
Unión de $\left[{ }^{3} \mathrm{H}\right] \mathrm{FNZ}$ \\ $\mathrm{K}_{\mathrm{d}}(\mathrm{nM}) \quad \mathrm{B}_{\max }(\mathrm{pmol} / \mathrm{mg}$ prot $)$
}

$\begin{array}{lll}\text { Control } & 0.37 \pm 0.04 & 37.51 \pm 3.88\end{array}$

7 días DZ $\quad 0.55 \pm 0.07 \quad 48.10 \pm 4.66$

14 días DZ $\quad 0.55 \pm 0.07 \quad 48.10 \pm 4.66$

Los animales fueron tratados con vehículo (control) o diacepam (DZ) durante 7 o 14 días. Los homogenatos de membrana fueron preparados a partir de las cortezas cerebrales. Los datos representan las medias \pm S.E.M. de 3 experimentos independientes realizados por triplicado.

Resultados obtenidos a partir de experimentos llevados a cabo en una línea celular expresando receptores $\mathrm{GABA}_{\mathrm{A}}$ recombinantes sugieren que la exposición prolongada a diacepam induce un aumento en la internalización de los receptores en vesículas intracelulares (Ali and Olsen 2001). Dado que estos compartimentos intracelulares, los cuales están presentes en nuestras preparaciones de membrana, son permeables a las benzodiacepinas pero no al GABA, es posible que la reducción en la potenciación de la unión de FNZ por GABA observado luego de los tratamientos crónicos con diacepam sea el resultado de un incremento en la endocitosis del receptor. Con el objeto de investigar esta 
posibilidad, estudiamos el efecto de un tratamiento con agua bidestilada en la preparación de membranas (shock osmótico) para lisar los compartimentos intracelulares (Tabla II).

Tabla II Efecto del shock osmótico sobre el desacoplamiento inducido por diacepam

\begin{tabular}{lc}
\hline Tratamiento & $\begin{array}{c}\left.\text { Unión de }{ }^{3} \mathrm{H}\right] \mathrm{FNZ} \text { estimulada por } \\
\text { GABA }\end{array}$ \\
& $(\%$ acoplamiento $)$ \\
\hline Control & 100 \\
DZ & $44 \pm 11^{\mathrm{a}}$ \\
7 días & $38 \pm 10^{\mathrm{a}}$ \\
14 días & 100 \\
Control, shock osmótico & \\
DZ, shock osmótico & \\
7 días & $42 \pm 10^{\mathrm{a}}$ \\
14 días & $53 \pm 9^{\mathrm{a}}$
\end{tabular}

Los animales fueron tratados con vehículo (control) o diacepam (DZ) durante 7 o 14 días. Homogenatos de membrana fueron preparados a partir de las cortezas cerebrales. Un tratamiento de shock osmótico fue realizado en algunas de las preparaciones como es indicado. El acoplamiento entre el GABA y las benzodiacepinas fue estimado como la potenciación de la unión de [ $\left.{ }^{3} \mathrm{H}\right] \mathrm{FNZ}$ por GABA. Los datos representan las medias \pm S.E.M. de 3-4 experimentos independientes realizados por triplicado. Significativamente diferente del control: ${ }^{a} \mathrm{p}<0.05$ (test $t$ de Student) 
Los resultados obtenidos indican que el tratamiento no inhibió el desacoplamiento inducido por diacepam sugiriendo que este efecto no es el resultado de un proceso de internalización de receptores $\mathrm{GABA}_{\mathrm{A}}$.

\section{La administración crónica con diacepam induce un aumento en los niveles de ARN mensajero y proteína de la subunidad $\alpha 1$ del receptor $\mathrm{GABA}_{\mathrm{A}}$}

Ha sido demostrado que la acción de las benzodiacepinas depende del subtipo de subunidad $\alpha$ presente en el receptor $\mathrm{GABA}_{\mathrm{A}}$ con el siguiente orden: $\alpha 3>\alpha 1 / \alpha 5$ (Puia, Vicini et al. 1991; Wafford, Whiting et al. 1993; Smith, Alder et al. 2001). Por lo tanto, es posible que la tolerancia sea el resultado de una disminución en el número de receptores conteniendo la subunidad $\alpha 3$ y/o un aumento en el número de receptores conteniendo las subunidades $\alpha 1 / \alpha 5$. Para comprobar esta hipótesis, en una primera etapa se realizaron experimentos de PCR cuantitativa en tiempo real para medir el efecto de los tratamientos crónicos con diacepam sobre los niveles de ARN mensajero de las subunidades $\alpha 1, \alpha 3$ y $\alpha 5$ en la corteza cerebral de rata (Fig. 19).

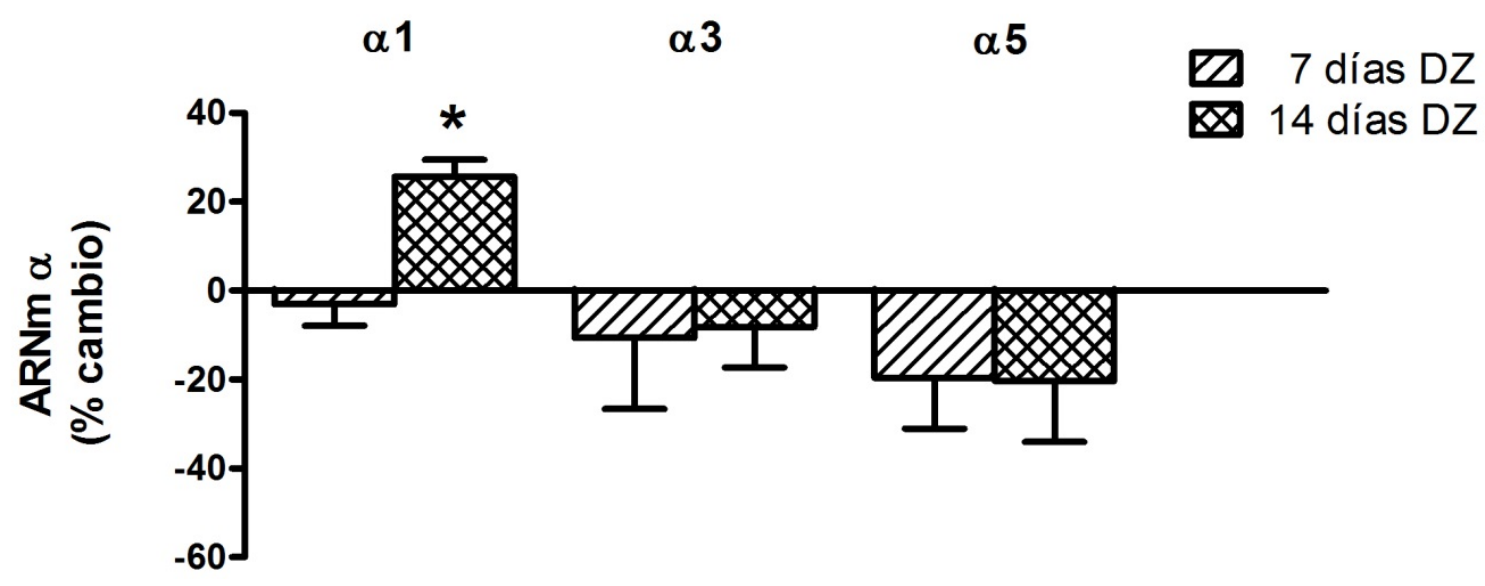

Figura 19: Efecto del tratamiento crónico con diacepam sobre los niveles de ARN mensajero de las subunidades $\alpha 1, \alpha 3$ y $\alpha 5$ del receptor $\mathbf{G A B A}_{\mathbf{A}}$. Los animales fueron tratados durante 7 o 14 días con diacepam (DZ) o vehículo (control). Los resultados se expresan como porcentaje de 
cambio con respecto al control (0 \%). Los datos representan las medias \pm SEM de 4 determinaciones independientes. * Significativamente diferente de $0, \mathrm{p}<0,05$ (test $t$ de Student de una sola muestra).

El tratamiento crónico con diacepam indujo un aumento en los niveles de ARN mensajero de la subunidad $\alpha 1$ del receptor $\mathrm{GABA}_{\mathrm{A}}$ luego del tratamiento crónico de 14 días con diacepam pero no se observó ningún cambio a los 7 días de tratamiento. No se detectaron alteraciones en los niveles de ARN mensajero de las subunidades $\alpha 3$ y $\alpha 5$ con ningún tratamiento.

Con el objeto de verificar que el aumento en los niveles de ARN mensajero de la subunidad $\alpha 1$ del receptor esté acompañado por el incremento en los niveles de proteína de esta subunidad, se llevaron a cabo experimentos de western blot (Fig. 20).

A

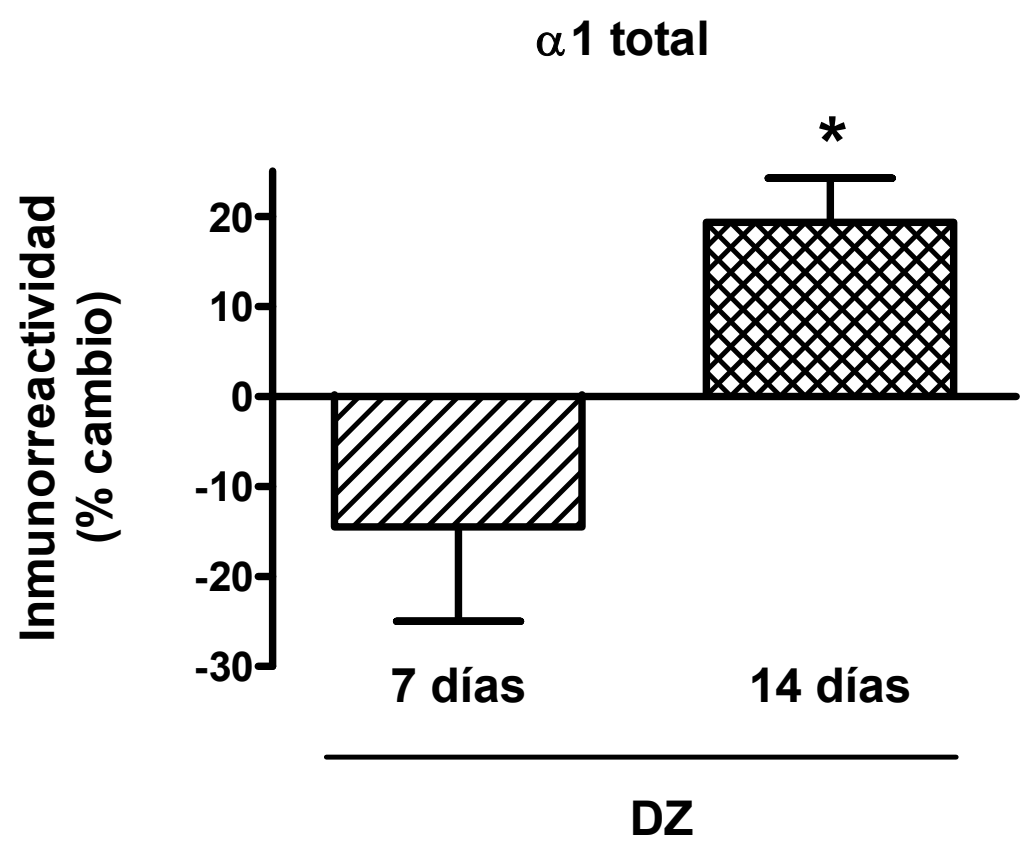




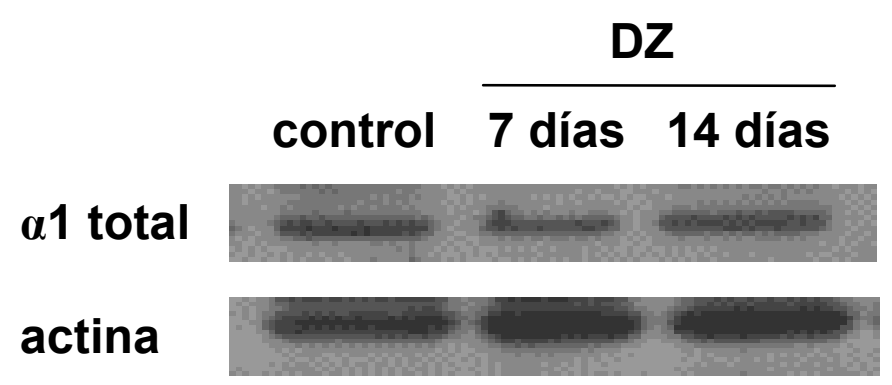

Figura 20: Efecto del tratamiento crónico con diacepam sobre la subunidad $\alpha 1$ del receptor GABA $\mathbf{A}_{\mathbf{A}}$. Los animales fueron tratados durante 7 o 14 días con diacepam o vehículo (control). A. Los resultados fueron normalizados con respecto a los niveles de actina y se expresan como porcentaje de cambio con respecto al control. Los datos representan las medias \pm SEM de 4 determinaciones independientes. * Significativamente diferente de $0, \mathrm{p}<0,05$ (test $t$ de Student de una sola muestra). B. Experimento representativo de western blot

Estos resultados sugieren un aumento en los niveles totales de la subunidad $\alpha 1$ del receptor $\mathrm{GABA}_{\mathrm{A}}$ que estaría asociado al desarrollo de tolerancia a los efectos ansiolíticos del diacepam.

\section{Cambios en la composición de subunidades del receptor $\mathrm{GABA}_{\mathrm{A}}$ inducidos por el tratamiento crónico con diacepam}

Si bien existen evidencias indicando que la administración crónica de benzodiacepinas no induce cambios en el número de receptores GABA (Gallager, Lakoski et al. 1984; Brett and Pratt 1995), ha sido reportado que este tratamiento induce alteraciones selectivas en los niveles de las subunidades del receptor (Uusi-Oukari and Korpi 2010). Sin embargo, no se ha investigado hasta el momento si el tratamiento crónico con benzodiacepinas induce cambios en la composición de subunidades del receptor $\mathrm{GABA}_{\mathrm{A}}$. Dado que nuestros resultados demuestran que el tratamiento crónico con diacepam produce 
un aumento en los de la subunidad $\alpha 1$ del receptor, investigamos si este incremento resulta en un aumento en el porcentaje de receptores conteniendo esa subunidad mediante ensayos de inmunoprecipitación de receptores seguidos por experimentos de western blot (Fig. 21).

Los receptores $\mathrm{GABA}_{\mathrm{A}}$ de la corteza cerebral de rata fueron inmunoprecipitados con un anticuerpo que reconoce la subunidad $\gamma 2$, pues esta subunidad está presente en la mayoría de los receptores. El inmunoprecipitado fue analizado por medio de ensayos de western blot utilizando anticuerpos dirigido contra las subunidades $\alpha 1, \alpha 3$ o $\alpha 5$.

\section{A}

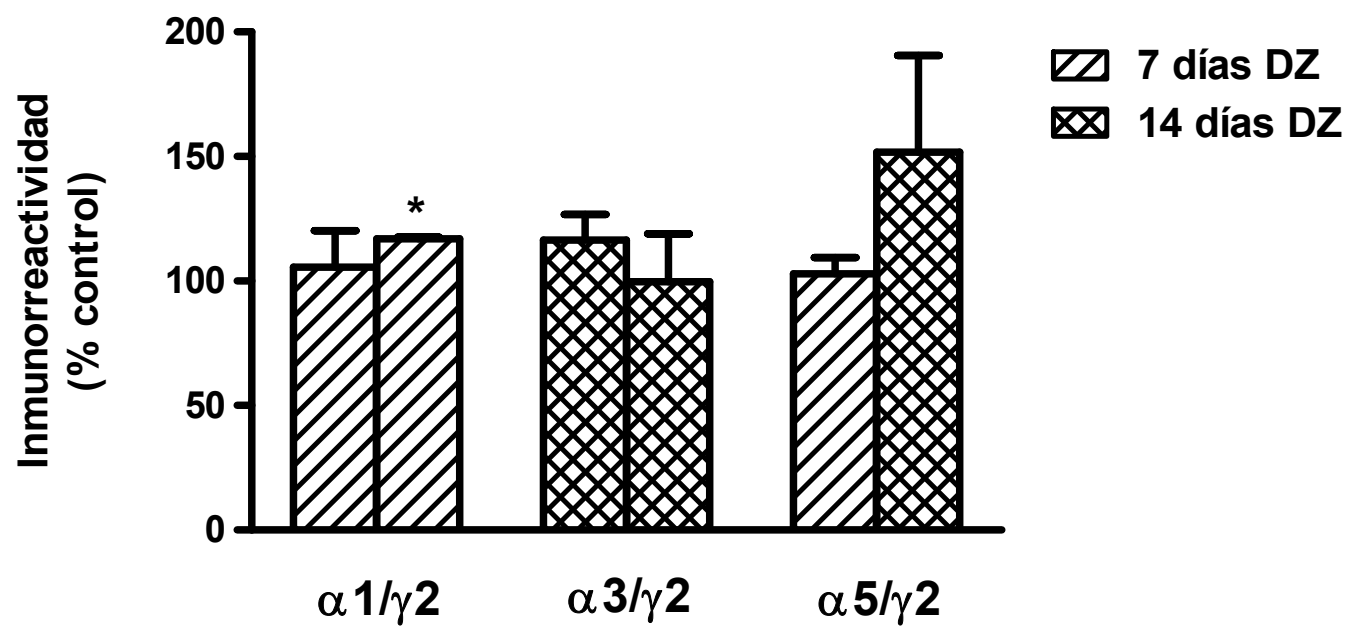




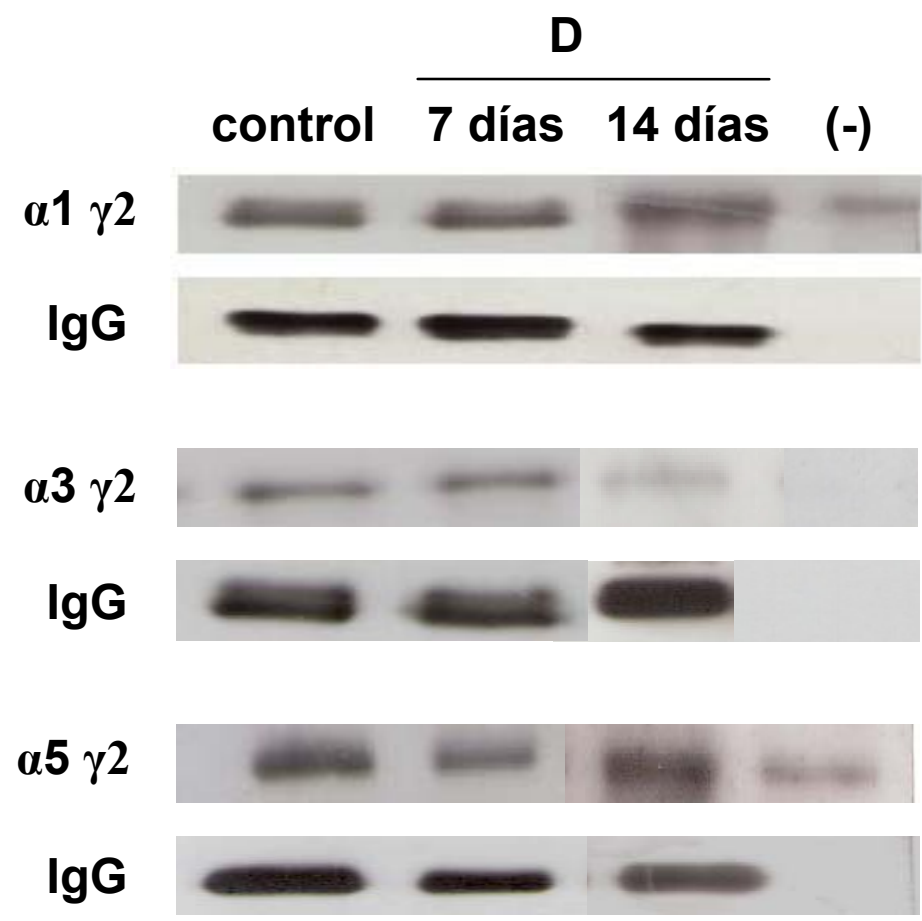

Figura 21: Efecto del tratamiento crónico con diacepam sobre la composición de subunidades del receptor $\mathbf{G A B A}_{\mathbf{A}}$. Los animales fueron tratados durante 7 o 14 días con diacepam (DZ) o vehículo (control). A. Los resultados normalizados (con respecto a los niveles de IgG utilizada en la inmunoprecipitación) se expresan como porcentaje de cambio con respecto al control (100\%). Los datos representan las medias \pm SEM de 3 a 6 determinaciones independientes. * Significativamente diferente de 100, p<0,05 (test $t$ de Student de una sola muestra).B. Experimento representativo de western blot. (-) Control negativo (inmunoprecipitación en ausencia de anticuerpo anti $\gamma 2$ ).

En concordancia con el aumento en los niveles de la subunidad $\alpha 1$ del receptor $\mathrm{GABA}_{\mathrm{A}}$ inducido por el tratamiento crónico de 14 días con diacepam, se observó un aumento en el porcentaje de receptores conteniendo $\alpha 1$ como resultado de este tratamiento. En contraste, no se observó ningún cambio en la proporción de receptores $\mathrm{GABA}_{\mathrm{A}}$ compuestos por la subunidad al luego del tratamiento de 7 días con la benzodiacepina. Tampoco se observaron alteraciones en el número de receptores conteniendo las 
subunidades $\alpha 3$ o $\alpha 5$ con ninguno de los dos tratamientos crónicos. Estos resultados sugieren que la tolerancia a los efectos ansiolíticos del diacepam estaría acompañada por un aumento en la subunidad $\alpha 1$ del receptor como así también en el porcentaje de receptores $\mathrm{GABA}_{\mathrm{A}}$ conteniendo dicha subunidad.

\section{Efecto de la administración crónica de diacepam sobre el estado de fosforilación del receptor $\mathbf{G A B A}_{\mathbf{A}}$}

Resultados a partir de experimentos realizados con líneas celulares expresando receptores $\mathrm{GABA}_{\mathrm{A}}$ recombinantes sugieren que la exposición crónica a benzodiacepinas conduce a la activación de diferentes proteínas quinasas (Johnston, Price et al. 1998; Ali and Olsen 2001).

Estudios realizados por nuestro grupo en cultivos primarios de corteza cerebral de rata, demuestran que el desacoplamiento inducido por la activación continua del receptor $\mathrm{GABA}_{\mathrm{A}}$ por GABA está acompañado por un incremento en el estado de fosforilación de residuos serina de la subunidad $\gamma 2$ (Gutierrez, Ferreri et al. 2014). En el presente trabajo se investigó si los tratamientos crónicos con diacepam producen cambios en el estado de fosforilación del residuo serina 327 de la subunidad $\gamma 2$ del receptor $\mathrm{GABA}_{\mathrm{A}}$ en la corteza cerebral de rata pues es uno de los principales residuos serina susceptibles de fosforilación de dicha subunidad. A tal fin, se efectuaron ensayos de western blot (Fig. 22). 
A
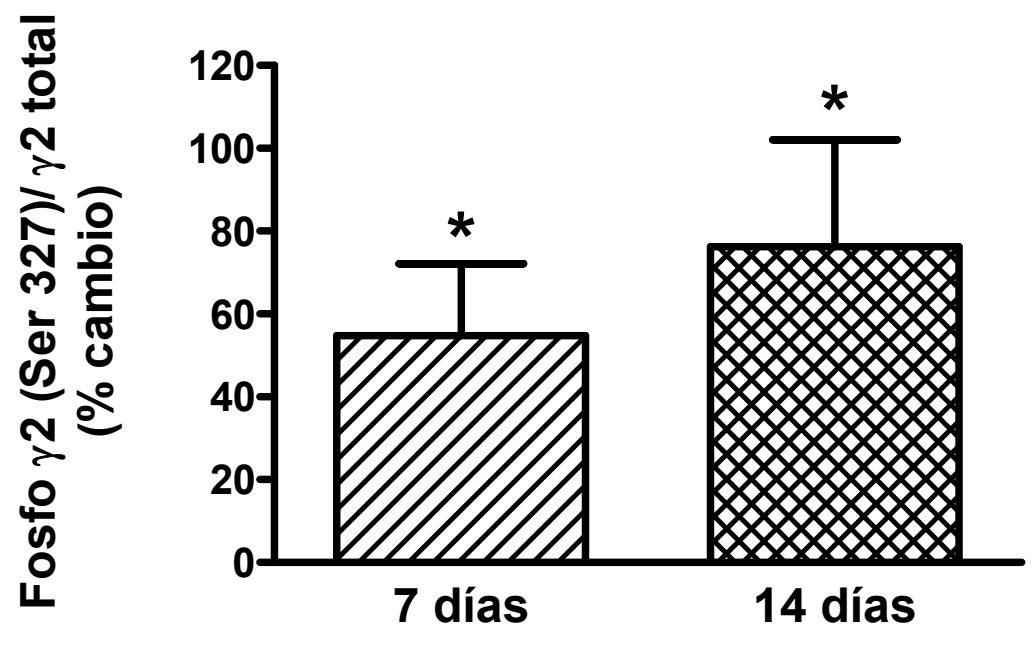

DZ

B

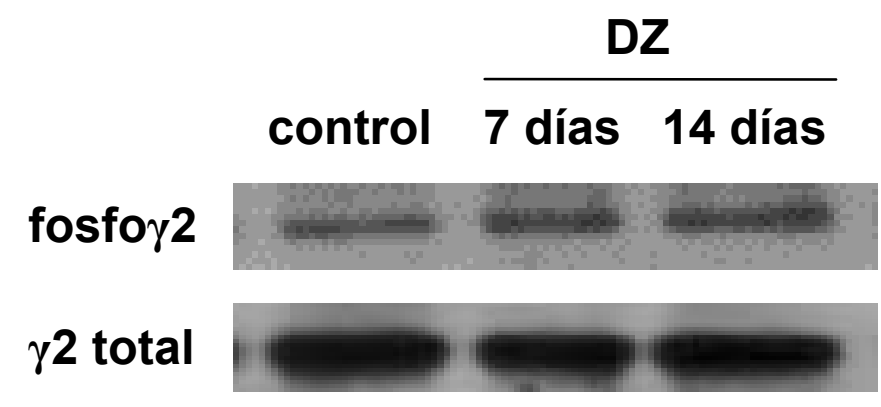

Figura 22: Efecto del tratamiento crónico con diacepam sobre el estado de fosforilación de la subunidad $\gamma 2$ del receptor $\mathbf{G A B A}_{\mathbf{A}}$. Los animales fueron tratados durante 7 o 14 días con diacepam o vehículo (control). A. Los resultados normalizados (con respecto a los niveles de $\gamma 2$ totales) se expresan como porcentaje de cambio con respecto al control (0\%). Los datos representan las medias \pm SEM de 4 determinaciones independientes. * Significativamente diferente de $0, \mathrm{p}<0,05$ (test $t$ de Student de una sola muestra). B. Experimento representativo de western blot. 
Nuestros experimentos demuestran que la exposición crónica a diacepam durante 7 días produjo un aumento en el grado de fosforilación de la subunidad $\gamma 2$ del receptor $\mathrm{GABA}_{\mathrm{A}}$ que se mantuvo luego del tratamiento de 14 días. Por lo tanto, estos resultados sugieren que la manifestación de tolerancia a los efectos sedativos de las benzodiacepinas está asociada a un cambio el estado de fosforilación del receptor.

\section{Efecto de la exposición crónica a diacepam de neuronas de corteza cerebral en cultivo sobre la interacción entre los sitios de unión de GABA y benzodiacepinas}

Los cultivos neuronales han sido ampliamente utilizados para el estudio del mecanismo molecular de la tolerancia a las benzodiacepinas. Con el objetivo de completar de estudiar el mecanismo molecular de la tolerancia a las benzodiacepinas se emplearon cultivos neuronales primarios de corteza cerebral de rata expuestos crónicamente a diacepam.

\subsection{La exposición crónica de neuronas de corteza cerebral a diacepam induce el desacoplamiento entre los sitios de unión de GABA y benzodiacepinas}

Los resultados obtenidos en experimentos ex vivo con cultivos primarios parecen reproducir los experimentos in vivo de administración crónica de benzodiacepinas. Ha sido reportado que la exposición crónica (durante 48 horas) de cultivos neuronales de cerebro de pollo a fluracepam produce desacoplamiento entre los sitios de unión de GABA y benzodiacepinas (Roca, Schiller et al. 1990). Con el objeto de verificar si el tratamiento crónico con diacepam induce también desacoplamiento en neuronas de corteza cerebral de rata, se investigó el efecto de la exposición de cultivos primarios a diacepam durante 48 horas mediante experimentos de unión de $\left[{ }^{3} \mathrm{H}\right] \mathrm{FNZ}$ estimulada por GABA (Fig. 23). 


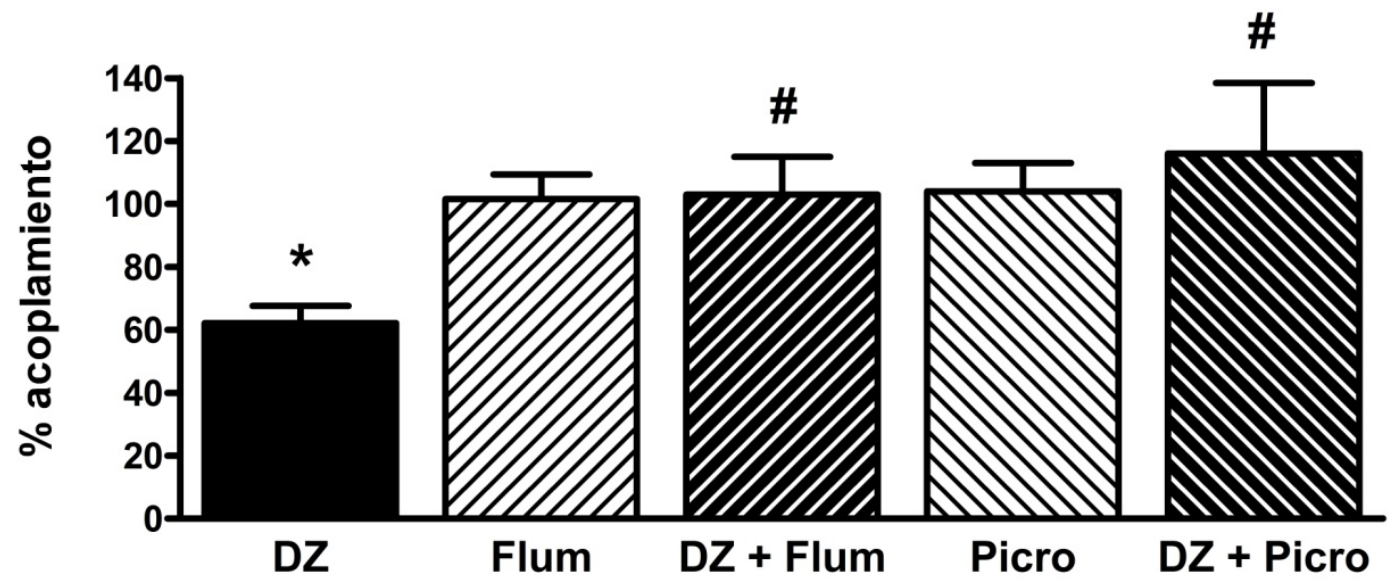

Figura 23: Grado de acoplamiento entre los sitios de unión a GABA y benzodiacepinas en neuronas de corteza cerebral expuestas crónicamente a diacepam. Cultivos primarios de corteza cerebral de rata fueron expuestos durante 48 horas a vehículo, diacepam (DZ), flumacenil (Flum), diacepam más flumacenil (DZ + Flum), picrotoxina (Picro) o diacepam más picrotoxina (DZ + Picro). Los resultados se expresan como porcentaje de acoplamiento con respecto al control (tratamiento con vehículo, $100 \%$ ). Los datos representan las medias \pm SEM de 4 a 6 determinaciones independientes. Diferencias significativas: ${ }^{*} \mathrm{DZ}$ versus control, definido como 100 $\%(\mathrm{p}<0,05$, test $t$ de Student de una sola muestra), \# DZ + Flum versus DZ y DZ + Picro versus DZ $(\mathrm{p}<0,05$, ANOVA de una vía y test de Tukey).

Los resultados muestran que la exposición prolongada de las neuronas en cultivo a diacepam induce, al igual que los tratamientos in vivo, una reducción en el grado de acoplamiento entre los sitios de unión de GABA y benzodiacepinas. Este desacoplamiento es prevenido en presencia de flumacenil, un antagonista del sitio de unión de benzodiacepinas, demostrando la especificidad de la acción del diacepam.

Con el objeto de evaluar si el desacoplamiento inducido por diacepam depende de la activación del receptor $\mathrm{GABA}_{\mathrm{A}}$, se evaluó el efecto de picrotoxina, un bloqueante del canal iónico del receptor (Fig. 23). Estos resultados muestran que en presencia de picrotoxina el 
desacoplamiento inducido por diacepam es bloqueado, indicando que este proceso requiere de la activación del canal del receptor $\mathrm{GABA}_{\mathrm{A}}$.

7.2 Rol de la activación de CCDV-L sobre el desacoplamiento inducido por la exposición crónica a diacepam

Ha sido reportado que la reducción inducida por la administración crónica de benzodiacepinas de las corrientes mediadas por el receptor $\mathrm{GABA}_{\mathrm{A}}$ está mediada por la activación de CCDV-L. Con el objeto de investigar si el desacoplamiento inducido por el tratamiento con diacepam depende la activación de dichos canales se investigó el efecto de nifedipina, un bloqueante de CCDV-L (Fig. 24).

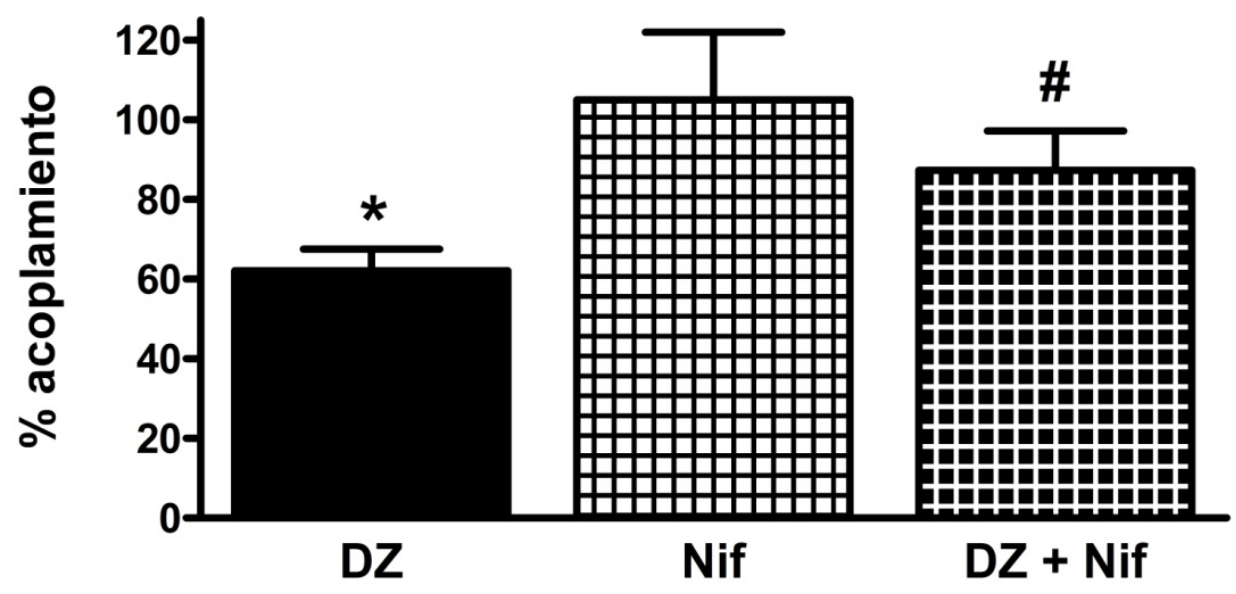

Figura 24: El desacoplamiento inducido por diacepam es inhibido en presencia de nifedipina. Los cultivos de neuronas de corteza cerebral fueron tratados durante 48 horas con vehículo, diacepam (DZ), nifedipina (Nif) o diacepam más nifedipina (DZ + Nif). Los resultados se expresan como porcentaje de acoplamiento con respecto al control (tratamiento con vehículo, 100 \%). Los datos representan las medias \pm SEM de 4 a 6 determinaciones independientes. Diferencias significativas: * DZ versus control, definido como $100 \%(\mathrm{p}<0,05$, test $t$ de Student de una sola muestra), \# DZ + Nif versus DZ ( $\mathrm{p}<0,05$, ANOVA de una vía y test de Tukey). 
El desacoplamiento inducido por diacepam fue prevenido en presencia de nifedipina indicando que este fenómeno depende del flujo de calcio a través de los CCDV-L. 
DISCUSIÓN 
La comprensión del mecanismo de tolerancia a las benzodiacepinas es muy importante desde un punto de vista clínico pues estas drogas, que poseen un alto índice terapéutico, podrían ser prescriptas para tratamientos prolongados. Dado que las benzodiacepinas estimulan alostéricamente las acciones del GABA mediante la unión a receptores $\mathrm{GABA}_{\mathrm{A}}$, estos receptores son posibles candidatos para mediar las alteraciones adaptativas inducidas por el consumo prolongado de benzodiacepinas.

En el presente trabajo investigamos el mecanismo de tolerancia a las benzodiacepinas inducida por la administración crónica de diacepam durante 7 o 14 días. Nuestros resultados demuestran que la tolerancia a las acciones sedativas del diacepam se manifiesta luego de los tratamientos de 7 y 14 días mientras que la tolerancia a los efectos ansiolíticos es detectada solamente luego del tratamiento de 14 días (Fig. 15 y 16). Estos resultados están de acuerdo a las evidencias previas que demuestran que la tolerancia a las benzodiacepinas se desarrolla con diferentes cursos temporales dependiendo de la acción farmacológica (Bateson 2002; Vinkers and Olivier 2012).

Con el objeto de investigar si alteraciones en parámetros farmacocinéticos pueden contribuir al desarrollo de tolerancia, se midió la concentración de diacepam en la corteza cerebral por HPLC luego de los distintos tratamientos (Fig. 17). La concentración de diacepam en la corteza cerebral luego del tratamiento de 7 días fue similar a la del grupo que recibió el tratamiento agudo. Sin embargo, en animales tratados con diacepam por 14 días se detectó un aumento en los niveles de diacepam en la corteza cerebral comparado con el grupo agudo. Estos datos indican que se produjo acumulación de droga luego del tratamiento más prolongado que pudo deberse a una saturación de las vías metabólicas como ha sido previamente reportado como consecuencia de la administración de altas concentraciones de diacepam (St-Pierre and Pang 1995). Los valores de concentración corticales de diacepam reportados en este trabajo son muy similares a los reportados en un estudio previo donde se realizaron tratamientos crónicos semejantes (Fernandes, Arnot et al. 1999). Nuestros resultados están de acuerdo con trabajos previos donde demuestran que las concentraciones plasmáticas y corticales de diferentes benzodiacepinas no disminuyen a lo largo del tiempo durante tratamientos prolongados (Miller, Greenblatt et al. 1988; Cowley, Roy-Byrne et al. 1995; Fernandes, File et al. 1996). En conclusión, los resultados 
presentados en este trabajo demuestran que cambios en factores farmacocinéticos no son parte del mecanismo de tolerancia.

La disminución en la eficacia de las benzodiacepinas inducida por la exposición crónica podría ser mediada por una reducción en el acoplamiento alostérico entre los sitios de unión de GABA y benzodiacepinas. Diversos trabajos demuestran que la administración prolongada in vivo de benzodiacepinas produce desacoplamiento de las interacciones entre los sitios de unión de GABA y benzodiacepinas. El desacoplamiento ha sido detectado empleando distintas metodologías experimentales, por ejemplo, como una disminución en la habilidad de zolpidem para prolongar el decaimiento de las corrientes post-sinápticas inhibitorias miniatura en el hipocampo de rata (Tietz, Zeng et al. 1999), una reducción en la potenciación del influjo de cloruro estimulado por GABA en corteza cerebral de rata (Marley and Gallager 1989) y una disminución en la estimulación de la unión de benzodiacepinas por GABA en corteza cerebral de rata (Gallager, Lakoski et al. 1984; Tietz, Chiu et al. 1989).

Los resultados de este trabajo demuestran que los tratamientos crónicos con diacepam durante 7 y 14 días resultan en desacoplamiento de las interacciones entre los sitios de unión de GABA y benzodiacepinas en la corteza cerebral de rata (Fig. 18). Por lo tanto, la tolerancia al efecto sedativo del diacepam podría ser la consecuencia de un proceso de desacoplamiento. Este desacoplamiento ocurre en ausencia de cambios en el número o afinidad de los sitios de unión de benzodiacepinas. Debido a que la ocurrencia de desacoplamiento precede a la manifestación de tolerancia a los efectos ansiolíticos del diacepam, la tolerancia a este efecto farmacológico parece ser mediado por un mecanismo diferente. Los resultados obtenidos por Holt y col. (Holt, Bateson et al. 1999) indican que una única inyección de diacepam induce desacoplamiento en la corteza cerebral y cerebelo de rata, sugiriendo que este fenómeno no es parte del mecanismo de tolerancia. Sin embargo, la relevancia del desacoplamiento al desarrollo de tolerancia a ciertos efectos farmacológicos de las benzodiacepinas es avalado por diferentes estudios. Ha sido demostrado que el grado de desacoplamiento detectado en la corteza cerebral por tratamientos crónicos con distintos ligandos del sitio de las benzodiacepinas se correlaciona con la magnitud de tolerancia a las acciones anticonvulsivantes producida por estos 
compuestos (Hernandez, Heninger et al. 1989). Además, Tietz y col. (Tietz, Chiu et al. 1989) demostraron que el tratamiento crónico pero no el agudo con benzodiacepinas produce desacoplamiento en la corteza cerebral, sugiriendo que esta alteración es producida por la exposición crónica. Resultados similares son presentados en este trabajo ya que no detectamos desacoplamiento luego del tratamiento agudo con diacepam.

La administración prolongada de benzodiacepinas produce desacoplamiento en forma dependiente de la región. Los estudios de Marley y col. (Marley and Gallager 1989) indican que una disminución en la sensibilidad del influjo de cloruro estimulado por GABA al FNZ se observa en la corteza cerebral pero no en cerebelo de ratas tratadas crónicamente con diacepam. De la misma forma, Tietz y col. (Tietz, Chiu et al. 1989) demostraron que un tratamiento crónico con flurazepam en ratas produce una reducción en la habilidad del GABA para estimular la unión de flunitracepam en la corteza cerebral, mientras que no se observó desacoplamiento en el cerebelo, médula, estriado, hipotálamo, cerebro medio, hipocampo y bulbo olfatorio. Estos datos indicarían que el mecanismo de tolerancia depende de la región del cerebro involucrada.

El mecanismo de tolerancia podría involucrar la expresión de receptores $\mathrm{GABA}_{\mathrm{A}}$ aberrantes debido a alteraciones en la composición de subunidades. Numerosos estudios reportaron cambios en la expresión de las subunidades del receptor $\mathrm{GABA}_{\mathrm{A}}$ pero los resultados son muy variados (Uusi-Oukari and Korpi 2010). Diferencias metodológicas, tales como especie, droga, longitud del tratamiento, ruta de administración, región del cerebro analizada, etc., contribuyen a las diferencias en los resultados publicados. La acción de las benzodiacepinas depende del subtipo particular de subunidad $\alpha$ del receptor $\mathrm{GABA}_{\mathrm{A}}$ (Puia, Vicini et al. 1991; Wafford, Whiting et al. 1993; Smith, Alder et al. 2001), sugiriendo que alteraciones en este subtipo de subunidad son responsables del desarrollo de tolerancia. Los resultados presentados en el presente trabajo indican que la manifestación de tolerancia a los efectos sedativos del diacepam luego del tratamiento de 7 días con diacepam ocurre en ausencia de cambios en la expresión de las subunidades $\alpha 1, \alpha 3$ o $\alpha 5$ del receptor $\mathrm{GABA}_{\mathrm{A}}$. En contraste, el tratamiento de 14 días con diacepam produce un aumento en los niveles de ARNm y péptido de la subunidad $\alpha 1$ del receptor $\mathrm{GABA}_{\mathrm{A}}$ que resulta en un incremento en el porcentaje de receptores conteniendo dicha subunidad (Fig. 
19, 20 y 21). Estos datos sugieren que la tolerancia a los efectos ansiolíticos del diacepam estaría mediada por un cambio en la composición de subunidades del receptor $\mathrm{GABA}_{\mathrm{A}}$.

La función y el tráfico intracelular de los receptores $\mathrm{GABA}_{\mathrm{A}}$ son controlados por la fosforilación de residuos localizados en el principal bucle intracelular de las subunidades del receptor (Kittler and Moss 2003; Song and Messing 2005; Comenencia-Ortiz, Moss et al. 2014). Dado que este proceso de fosforilación regula la acción de moduladores alostéricos del receptor $\mathrm{GABA}_{\mathrm{A}}$ (Hodge, Mehmert et al. 1999; Gao and Greenfield 2005), es posible que el fenómeno de desacoplamiento inducido por el tratamiento crónico con diacepam involucre un cambio en el estado de fosforilación del receptor. Previamente demostramos el desacoplamiento inducido por la continua activación del receptor $\mathrm{GABA}_{\mathrm{A}}$ por GABA en cultivos primarios de corteza cerebral de rata está mediado por un aumento en el grado de fosforilación de la subunidad $\gamma 2$ del receptor en residuos serina (Gutiérrez, Ferreri et al. 2014). En el presente trabajo observamos que el tratamiento crónico con diacepam por 7 días produce un aumento en el grado de fosforilación del residuo serina 327 de la subunidad $\gamma 2$ del receptor $\mathrm{GABA}_{\mathrm{A}}$ que se mantiene luego de 14 días de tratamiento (Fig. 22). Estos resultados sugieren que la tolerancia a los efectos sedativos del diacepam estaría mediada por un cambio en el estado de fosforilación del receptor $\mathrm{GABA}_{\mathrm{A}}$ en la corteza cerebral que resultaría en el desacoplamiento de las interacciones entre los sitios de unión de GABA y benzodiacepinas. En conjunto, los resultados de este trabajo sugieren que la tolerancia a los efectos sedativos y ansiolíticos del diacepam estarían mediados por diferentes alteraciones de la estructura y función del receptor $\mathrm{GABA}_{\mathrm{A}}$. Es posible, además, que el desacoplamiento y el aumento en el grado de fosforilación del receptor $\mathrm{GABA}_{\mathrm{A}}$, que persisten luego de 14 días de tratamiento, también contribuyan al desarrollo de tolerancia a los efectos ansiolíticos del diacepam. Por lo tanto, la tolerancia a las benzodiacepinas estaría mediada por múltiples mecanismos adaptativos que ocurren simultáneamente.

Nuestros previos trabajos realizados en cultivos de corteza cerebral de rata indican que el desacoplamiento inducido por GABA está mediado por un aumento en el grado de fosforilación dela subunidad $\gamma 2$ del receptor $\mathrm{GABA}_{\mathrm{A}} \mathrm{y}$ además está asociado a una disminución en el porcentaje de receptores conteniendo la subunidad $\alpha 3$, sin cambios en la proporción de receptores compuestos por la subunidad $\alpha 1, \alpha 3$ o $\alpha 5$ (Gutiérrez, Ferreri et al. 
2014; Gutiérrez, Ferreri et al. 2014). Si bien los resultados presentados aquí demuestran que el desacoplamiento inducido por el tratamiento crónico con diacepam está acompañado por la estimulación de la fosforilación de la subunidad $\gamma 2$ del receptor, no está correlacionado temporalmente con un cambio en la composición de subunidades del receptor. Por lo tanto, el desacoplamiento entre los sitios de unión de GABA y benzodiacepinas representaría un proceso de regulación de la función del receptor $\mathrm{GABA}_{\mathrm{A}}$ que podría ser inducido por múltiples mecanismos dependiendo del ligando que se una al receptor.

Los modelos de cultivos neuronales primarios han demostrado ser muy útiles para estudiar la regulación de la estructura y función del receptor $\mathrm{GABA}_{\mathrm{A}}$ por benzodiacepinas. Con el objeto de continuar estudiando el mecanismo molecular de la tolerancia a las benzodiacepinas, analizamos el efecto de la exposición crónica de cultivos primarios de corteza cerebral de rata a diacepam durante 48 horas. Los resultados de estos experimentos (Fig 23) indican que la exposición de los cultivos a diacepam resulta, al igual que los tratamientos in vivo, en un desacoplamiento significativo entre los sitios de unión de GABA y benzodiacepinas, estimado como una disminución en la potenciación de la unión de FNZ por GABA. Estas observaciones indicarían que este modelo de cultivos neuronales es apropiado para estudiar el efecto de la exposición crónica a benzodiacepinas. Este desacoplamiento es prevenido en presencia de flumacenil, un antagonista del sitio de unión de las benzodiacepinas, demostrando que el desacoplamiento está mediado por la unión del diacepam a su sitio de unión específico en el receptor $\mathrm{GABA}_{\mathrm{A}}$.

El desacoplamiento es además bloqueado por picrotoxina, un bloqueante del canal de cloruro, demostrando que es un proceso dependiente de la activación del receptor $\mathrm{GABA}_{\mathrm{A}}$ (Fig. 23). Estos resultados están de acuerdo con trabajos anteriores donde se demuestra que el desacoplamiento inducido por fluracepam en cultivos de corteza cerebral de pollo es reducido por la co-administración de bicuculina, un antagonista competitivo del receptor GABA $_{\mathrm{A}}$ (Prasad and Reynolds 1992). En contraste, otros dos estudios realizados en neuronas corticales de ratón (Hu and Ticku 1994) y neuronas de cerebro total de pollo (Roca, Schiller et al. 1990) indican que el desacoplamiento inducido por benzodiacepinas no es bloqueado por la co-incubación con otros antagonistas del receptor GABA $_{\mathrm{A}}$, RU5135 
y gabazina, respectivamente. Las diferencias en los tratamientos y en los cultivos neuronales utilizados podrían explicar esta discrepancia.

Ha sido reportado que la administración crónica de benzodiacepinas estimula las corrientes de calcio mediadas por los CCDV-L en hipocampo sugiriendo que la activación de estos canales contribuiría al mecanismo de tolerancia. Los resultados presentados en este trabajo (Fig. 24) indican que el desacoplamiento inducido por la exposición crónica de neuronas corticales a diacepam es prevenido por co-incubación con nifedipina, un bloqueante de los CCDV-L. Por consiguiente, el mecanismo de tolerancia a los efectos sedativos del diacepam, inducido por un tratamiento prolongado, podría estar mediado por un proceso de desacoplamiento que dependería de la activación de los CCDV-L. La estimulación de la entrada de calcio a través de estos canales podría activar a la PKC que a su vez fosforilaría la subunidad $\gamma 2$ del receptor $\mathrm{GABA}_{\mathrm{A}}$, lo cual resultaría en el desacoplamiento entre los sitios de unión de GABA y benzodiacepinas. En contraste con estos resultados, el desacoplamiento inducido por GABA en cultivos neuronales de corteza cerebral de rata (Gravielle, Faris et al. 2005) y de cerebro total de pollo (Lyons, Land et al. 2001) no es bloqueado por nifedipina y por lo tanto es independiente de la activación de los CCDV-L. Nuevamente, estas discrepancias podrían sugerir que el desacoplamiento puede ser mediado por diferentes mecanismos. 
CONCLUSIONES 
El objetivo del presente trabajo fue estudiar el mecanismo molecular de la tolerancia a los efectos sedativos y ansiolíticos de las benzodiacepinas utilizando un protocolo de administraciones crónicas in vivo de diacepam durante 7 o 14 días en ratas y un modelo ex vivo de cultivos primarios neuronales de corteza cerebral de rata expuestos crónicamente a diacepam. Los resultados del presente trabajo de tesis demuestran la tolerancia al efecto sedativo del diacepam se manifiesta a partir de los 7 días de tratamiento mientras que la tolerancia al efecto ansiolítico de la benzodiacepina se detecta luego del tratamiento de 14 días, en concordancia con las evidencias previas que indican que el desarrollo de tolerancia a las benzodiacepinas presenta diferentes cursos temporales dependiendo del efecto farmacológico. El desarrollo de tolerancia no es el resultado de cambios en factores farmacocinéticos que resulten en una disminución en la concentración del diacepam en la corteza cerebral.

Los resultados de este estudio parecen indicar que la tolerancia a los efectos sedativos y ansiolíticos del diacepam ocurre a través de diferentes mecanismos moleculares. La tolerancia a los efectos sedativos del diacepam está asociada con una disminución en el grado de interacción entre los sitios de unión de GABA y benzodiacepinas, llamada desacoplamiento, que podría estar mediado por un aumento en el grado de fosforilación de la subunidad $\gamma 2$ del receptor $\mathrm{GABA}_{\mathrm{A}}$ en la corteza cerebral. En cambio, la tolerancia a los efectos ansiolíticos del diacepam está asociada a un aumento en la expresión de la subunidad $\alpha 1$ del receptor $\mathrm{GABA}_{\mathrm{A}}$ en la corteza cerebral que resultaría en un aumento en el porcentaje de receptores conteniendo dicha subunidad (Fig. 25).

Los experimentos realizados en este trabajo demuestran que la exposición prolongada de cultivos primarios neuronales de corteza cerebral de rata a diacepam durante 48 horas induce, al igual que los tratamientos crónicos in vivo, desacoplamiento entre los sitios de unión de GABA y benzodiacepinas, sugiriendo que estos cultivos representan un modelo apropiado para el estudio de las bases moleculares de la tolerancia a las benzodiacepinas. Este desacoplamiento es inducido por la unión del diacepam a su sitio de unión específico en el receptor $\mathrm{GABA}_{\mathrm{A}}$, requiere la activación del canal del receptor y a su vez depende del flujo de calcio a través de la activación de los CCDV-L. Este aumento en la entrada de calcio podría inducir la activación de la PKC que a su vez fosforilaría a la subunidad $\gamma 2$ del 
receptor $\mathrm{GABA}_{\mathrm{A}}$, lo cual finalmente resultaría en el desarrollo de tolerancia a las benzodiacepinas (Fig. 25).

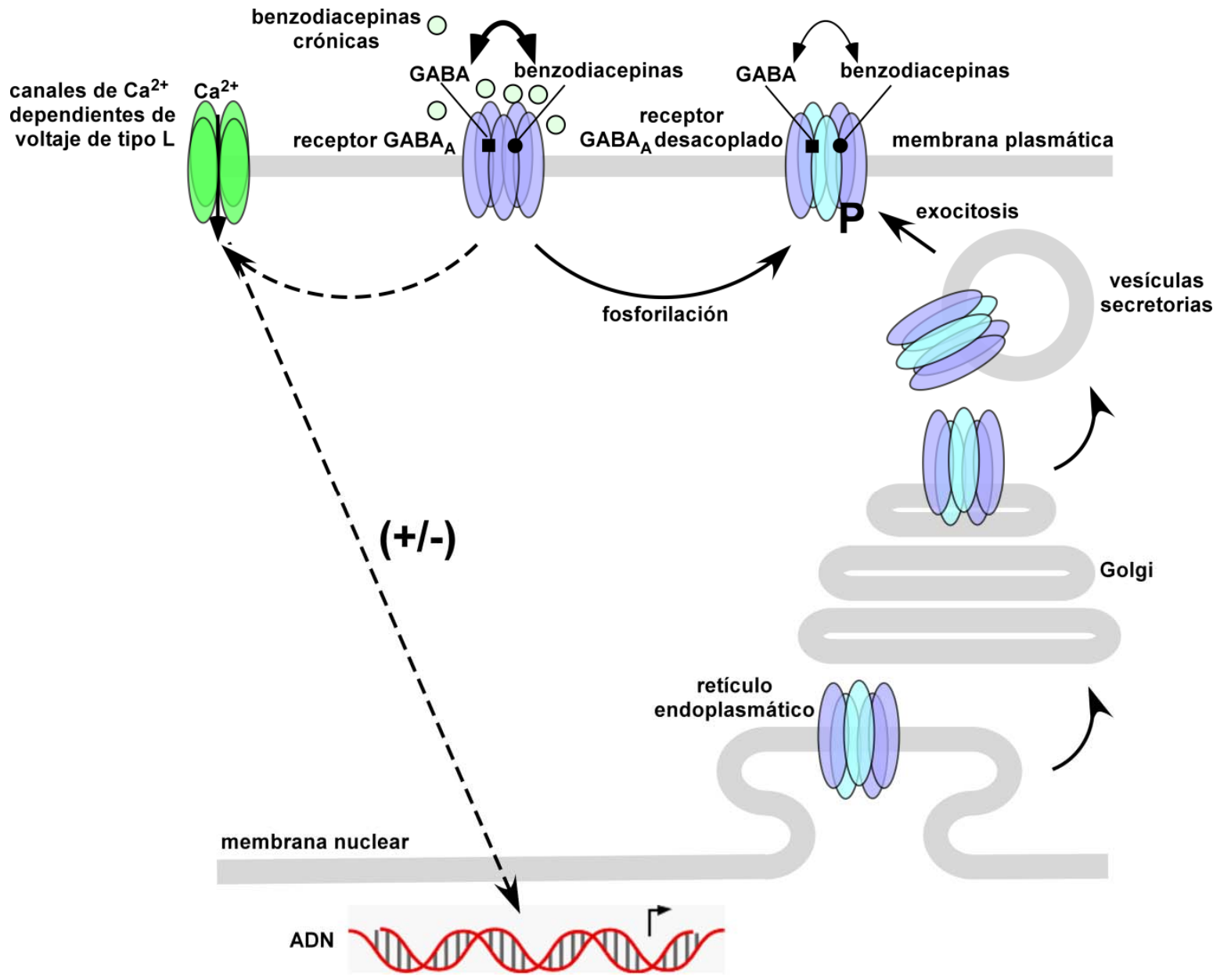

Figura 25: Alteraciones del receptor $\mathrm{GABA}_{\mathrm{A}}$ inducidas por la exposición prolongada a benzodiacepinas. El desarrollo de tolerancia a las benzodiacepinas estaría asociado a los siguientes cambios en el receptor $\mathrm{GABA}_{\mathrm{A}}$ : a) desacoplamiento de las interacciones entre los sitios de unión de GABA y benzodiacepinas, b) cambios en la composición de subunidades del receptor y c) aumento en el estado de fosforilación de la subunidad $\gamma 2$ del receptor. El desacoplamiento inducido por benzodiacepinas parece ser mediado por el aumento de flujo de calcio a través de canales de calcio dependientes de voltaje de tipo L. 


\section{BIBLIOGRAFÍA}


Akk, G., D. F. Covey, et al. (2007). "Mechanisms of neurosteroid interactions with GABA(A) receptors." Pharmacol Ther 116(1): 35-57.

Ali, N. J. and R. W. Olsen (2001). "Chronic benzodiazepine treatment of cells expressing recombinant $\mathrm{GABA}(\mathrm{A})$ receptors uncouples allosteric binding: studies on possible mechanisms." J Neurochem 79(5): 1100-1108.

Balon, R. (2013). "Benzodiazepines revisited." Psychother Psychosom 82(6): 353-354.

Bannai, H., S. Levi, et al. (2009). "Activity-dependent tuning of inhibitory neurotransmission based on GABAAR diffusion dynamics." Neuron 62(5): 670682.

Bateson, A. N. (2002). "Basic pharmacologic mechanisms involved in benzodiazepine tolerance and withdrawal." Curr Pharm Des 8(1): 5-21.

Bateson, A. N. (2004). "The benzodiazepine site of the GABAA receptor: an old target with new potential?" Sleep Med 5(Supplement 1): S9-S15.

Berezhnov D., G. M. C., and Farb D. H. (2007). Pharmacology of the GABAA receptor. The Handbook of Contemporary Neuropharmacology. I. H. David R. Sibley, Michael Kuhar, and Phil Skolnick, John Wiley \& Sons, Inc.: 465-569.

Bianchi, M. T. and R. L. Macdonald (2001). "Agonist Trapping by GABAA Receptor Channels." J Neurosci 21(23): 9083-9091.

Bormann, J. (2000). "The 'ABC' of GABA receptors." Trends Pharmacol Sci 21(1): 16-19.

Brett, R. R. and J. A. Pratt (1995). "Changes in benzodiazepine-GABA receptor coupling in an accumbens-habenula circuit after chronic diazepam treatment." $\underline{\mathrm{Br} \mathrm{J} \text { Pharmacol }}$ 116(5): 2375-2384.

Brooks-Kayal, A. R., Y. H. Raol, et al. (2009). "Alteration of epileptogenesis genes." Neurotherapeutics 6(2): 312-318.

Brooks-Kayal, A. R., M. D. Shumate, et al. (1998). "Selective changes in single cell GABA(A) receptor subunit expression and function in temporal lobe epilepsy." Nat Med 4(10): 1166-1172.

Comenencia-Ortiz, E., S. J. Moss, et al. (2014). "Phosphorylation of GABA receptors influences receptor trafficking and neurosteroid actions." Psychopharmacol (Berl) 231(17): 3453-3465. 
Cowley, D. S., P. P. Roy-Byrne, et al. (1995). "Benzodiazepine Sensitivity in Panic Disorder: Effects of Chronic Alprazolam Treatment." Neuropsychopharmacol 12(2): 147-157.

Chen, S., X. Huang, et al. (1999). "Benzodiazepine-mediated regulation of alpha1, alpha2, beta1-3 and gamma2 $\mathrm{GABA}(\mathrm{A})$ receptor subunit proteins in the rat brain hippocampus and cortex." Neurosci 93(1): 33-44.

Devaud LL, J.-M. F., Werner Sieghart, A. Leslie Morrow (1997). "Bidirectional Alterations of GABAA Receptor Subunit Peptide Levels in Rat Cortex During Chronic Ethanol Consumption and Withdrawal." J Neurochem 69(1): 126-130.

Downing, S. S., Y. T. Lee, et al. (2005). "Benzodiazepine modulation of partial agonist efficacy and spontaneously active GABAA receptors supports an allosteric model of modulation." Br J Pharmacol 145(7): 894-906.

Engelman, H. S. and A. B. MacDermott (2004). "Presynaptic ionotropic receptors and control of transmitter release." Nat Rev Neurosci 5(2): 135-145.

Estes, J. W. (1995). "The road to tranquility: the search for selective anti-anxiety agents." Synapse 21(1): 10-20.

Fernandes, C., M. I. Arnot, et al. (1999). "The effect of treatment regimen on the development of tolerance to the sedative and anxiolytic effects of diazepam." Psychopharmacol (Berl) 145(3): 251-259.

Fernandes, C., M. I. Arnot, et al. (1999). "The effect of treatment regimen on the development of tolerance to the sedative and anxiolytic effects of diazepam." Psychopharmacol 145(3): 251-259.

Fernandes, C., S. E. File, et al. (1996). "Evidence against oppositional and pharmacokinetic mechanisms of tolerance to diazepam's sedative effects." Brain Res 734(1-2): 236242.

Gallager, D. W., J. M. Lakoski, et al. (1984). "Chronic benzodiazepine treatment decreases postsynaptic GABA sensitivity." Nature 308(5954): 74-77.

Gao, L. and L. J. Greenfield (2005). "Activation of protein kinase C reduces benzodiazepine potency at GABAA receptors in NT2-N neurons." Neuropharmacol 48(3): 333-342. 
Gielen, M. C., M. J. Lumb, et al. (2012). "Benzodiazepines modulate GABAA receptors by regulating the preactivation step after GABA binding." J Neurosci 32(17): 57075715.

Gravielle, M. C., R. Faris, et al. (2005). "GABA induces activity dependent delayed-onset uncoupling of GABA/benzodiazepine site interactions in neocortical neurons." $\underline{\mathrm{J}}$ Biol Chem 280(22): 20954-20960.

Greenfield, L. J., Jr. (2013). "Molecular mechanisms of antiseizure drug activity at GABAA receptors." Seizure 22(8): 589-600.

Gutiérrez, M. L., M. C. Ferreri, et al. (2014). "GABA-induced uncoupling of GABA/benzodiazepine site interactions is associated with increased phosphorylation of the GABAA receptor." J Neurosci Res 92(8): 1054-1061.

Gutiérrez, M. L., M. C. Ferreri, et al. (2014). "GABA-induced uncoupling of GABA/benzodiazepine site interactions is mediated by increased GABA receptor internalization and associated with a change in subunit composition." Neurosci 257C: 119-129.

Haefely, W. E., J. R. Martin, et al. (1993). "The multiplicity of actions of benzodiazepine receptor ligands." Can J Psychiatry 38 Suppl 4: S102-108.

Herd, M. B., D. Belelli, et al. (2007). "Neurosteroid modulation of synaptic and extrasynaptic GABA(A) receptors." Pharmacol Ther 116(1): 20-34.

Hernandez, T. D., C. Heninger, et al. (1989). "Relationship of agonist efficacy to changes in GABA sensitivity and anticonvulsant tolerance following chronic benzodiazepine ligand exposure." Eur J Pharmacol 170(3): 145-155.

Hodge, C. W., K. K. Mehmert, et al. (1999). "Supersensitivity to allosteric GABA(A) receptor modulators and alcohol in mice lacking PKCepsilon." Nat Neurosci 2(11): 997-1002.

Holt, R. A., A. N. Bateson, et al. (1999). "Decreased GABA enhancement of benzodiazepine binding after a single dose of diazepam." J Neurochem 72(5): 22192222.

Houston, C. M., Q. He, et al. (2009). "CaMKII phosphorylation of the GABA(A) receptor: receptor subtype- and synapse-specific modulation." J Physiol 587(Pt 10): 21152125. 
Houston, C. M., H. H. Lee, et al. (2007). "Identification of the sites for CaMK-II-dependent phosphorylation of GABA(A) receptors." J Biol Chem 282(24): 17855-17865.

Hu, X. J. and M. K. Ticku (1994). "Chronic flurazepam treatment produces decreased efficacy of the benzodiazepine ligands and pentobarbital with gamma-aminobutyric acidA receptors in cortical neurons." J Pharmacol Exp Ther 270(2): 485-490.

Ito, T., T. Suzuki, et al. (1996). "Pharmacology of barbiturate tolerance/dependence: GABAA receptors and molecular aspects." Life Sci 59(3): 169-195.

Jacob, T. C., G. Michels, et al. (2012). "Benzodiazepine treatment induces subtype-specific changes in GABAA receptor trafficking and decreases synaptic inhibition." Proc Natl Acad Sci U S A 109(45): 18595-18600.

Jacob, T. C., S. J. Moss, et al. (2008). "GABA(A) receptor trafficking and its role in the dynamic modulation of neuronal inhibition." Nat Rev Neurosci 9(5): 331-343.

Jechlinger, M., R. Pelz, et al. (1998). "Subunit composition and quantitative importance of hetero-oligomeric receptors: GABAA receptors containing alpha6 subunits." $\underline{\mathrm{J}}$ Neurosci 18(7): 2449-2457.

Johnston, J. D., S. A. Price, et al. (1998). "Flunitrazepam rapidly reduces GABA(A) receptor subunit protein expression via a protein kinase C-dependent mechanism." Br J Pharmacol 124(7): 1338-1340.

Jurd, R., V. Tretter, et al. (2010). "Fyn kinase contributes to tyrosine phosphorylation of the GABA(A) receptor gamma2 subunit." Mol Cell Neurosci 44(2): 129-134.

Kittler, J. T. and S. J. Moss (2003). "Modulation of GABAA receptor activity by phosphorylation and receptor trafficking: implications for the efficacy of synaptic inhibition." Curr Opin Neurobiol 13(3): 341-347.

Klein, R. L., P. J. Whiting, et al. (1994). "Benzodiazepine treatment causes uncoupling of recombinant GABAA receptors expressed in stably transfected cells." J Neurochem 63(6): 2349-2352.

Laurie, D. J., W. Wisden, et al. (1992). "The distribution of thirteen GABAA receptor subunit mRNAs in the rat brain. III. Embryonic and postnatal development." $\underline{\mathrm{J}}$ Neurosci 12(11): 4151-4172. 
Leidenheimer, N. J. and R. Chapell (1997). "Effects of PKC activation and receptor desensitization on neurosteroid modulation of GABA(A) receptors." Brain Res Mol Brain Res 52(2): 173-181.

Leidenheimer, N. J., P. J. Whiting, et al. (1993). "Activation of calcium-phospholipiddependent protein kinase enhances benzodiazepine and barbiturate potentiation of the GABAA receptor." J Neurochem 60(5): 1972-1975.

Lyons, H. R., T. T. Gibbs, et al. (2000). "Turnover and down-regulation of GABA(A) receptor alpha1, beta2S, and gamma1 subunit mRNAs by neurons in culture." Neurochem 74(3): 1041-1048.

Lyons, H. R., M. B. Land, et al. (2001). "Distinct signal transduction pathways for GABAinduced $\mathrm{GABA}(\mathrm{A})$ receptor down-regulation and uncoupling in neuronal culture: a role for voltage-gated calcium channels." J Neurochem 78(5): 1114-1126.

Marley, R. J. and D. W. Gallager (1989). "Chronic diazepam treatment produces regionally specific changes in GABA-stimulated chloride influx." Eur J Pharmacol 159(3): 217-223.

McDonald, B. J., A. Amato, et al. (1998). "Adjacent phosphorylation sites on GABAA receptor beta subunits determine regulation by cAMP-dependent protein kinase." Nat Neurosci 1(1): 23-28.

Mehta, A. K. and M. K. Ticku (1999). "An update on GABAA receptors." Brain Res Brain Res Rev 29(2-3): 196-217.

Michels, G. and S. J. Moss (2007). "GABAA receptors: properties and trafficking." $\underline{\text { Crit }}$ Rev Biochem Mol Biol 42(1): 3-14.

Miller, L. G., D. J. Greenblatt, et al. (1988). "Chronic benzodiazepine administration. I. Tolerance is associated with benzodiazepine receptor downregulation and decreased gamma-aminobutyric acidA receptor function." J Pharmacol Exp Ther 246(1): 170176.

Moss, S. J., C. A. Doherty, et al. (1992). "Identification of the cAMP-dependent protein kinase and protein kinase $\mathrm{C}$ phosphorylation sites within the major intracellular domains of the beta 1 , gamma $2 \mathrm{~S}$, and gamma $2 \mathrm{~L}$ subunits of the gammaaminobutyric acid type A receptor." J Biol Chem 267(20): 14470-14476. 
Moss, S. J. and T. G. Smart (1996). "Modulation of amino acid-gated ion channels by protein phosphorylation." Int Rev Neurobiol 39: 1-52.

Pericic, D., D. Atrac, et al. (2007). "Allosteric uncoupling and up-regulation of benzodiazepine and GABA recognition sites following chronic diazepam treatment of HEK 293 cells stably transfected with $\alpha 1 \beta 2 \gamma 2 S$ subunits of GABAA receptors." Naunyn-Schmiedeberg's Arch Pharmacol 375(3): 177-187.

Pesold, C., H. J. Caruncho, et al. (1997). "Tolerance to diazepam and changes in GABA(A) receptor subunit expression in rat neocortical areas." Neurosci 79(2): 477-487.

Pirker, S., C. Schwarzer, et al. (2000). "GABA(A) receptors: immunocytochemical distribution of 13 subunits in the adult rat brain." Neurosci 101(4): 815-850.

Prasad, A. and J. N. Reynolds (1992). "Uncoupling of GABA-benzodiazepine receptors in chick cerebral cortical neurons requires co-activation of both receptor sites." Brain Res 591(2): 327-331.

Pratt, J. A., R. R. Brett, et al. (1998). "Benzodiazepine Dependence: From Neural Circuits to Gene Expression." Pharmacol Biochem Behav 59(4): 925-934.

Puia, G., S. Vicini, et al. (1991). "Influence of recombinant gamma-aminobutyric acid-A receptor subunit composition on the action of allosteric modulators of gammaaminobutyric acid-gated Cl- currents." Mol Pharmacol 39(6): 691-696.

Rajadhyaksha, A. M. and B. E. Kosofsky (2005). "Psychostimulants, L-type calcium channels, kinases, and phosphatases." Neuroscient 11(5): 494-502.

Ravindran, C. R. and M. K. Ticku (2006). "Tyrosine kinase phosphorylation of GABA(A) receptor alpha1, beta2 and gamma2 subunits following chronic intermittent ethanol (CIE) exposure of cultured cortical neurons of mice." Neurochem Res 31(9): 11111118.

Rivera, C., J. Voipio, et al. (2005). "Two developmental switches in GABAergic signalling: the K+-Cl- cotransporter KCC2 and carbonic anhydrase CAVII." J Physiol 562(Pt 1): 27-36.

Roca, D. J., I. Rozenberg, et al. (1990). "Chronic agonist exposure induces down-regulation and allosteric uncoupling of the gamma-aminobutyric acid/benzodiazepine receptor complex." Mol Pharmacol 37(1): 37-43. 
Roca, D. J., G. D. Schiller, et al. (1990). "gamma-Aminobutyric acidA receptor regulation in culture: altered allosteric interactions following prolonged exposure to benzodiazepines, barbiturates, and methylxanthines." Mol Pharmacol 37(5): 710719.

Rosenberg, H. C. and T. H. Chiu (1979). "Decreased 3H-diazepam binding is a specific response to chronic benzodiazepine treatment." Life Sci 24(9): 803-807.

Rosenberg, H. C. and T. H. Chiu (1981). "Tolerance during chronic benzodiazepine treatment associated with decreased receptor binding." Eur J Pharmacol 70(4): 453460.

Rudolph, U. and F. Knoflach (2011). "Beyond classical benzodiazepines: novel therapeutic potential of GABAA receptor subtypes." Nat Rev Drug Discov 10(9): 685-697.

Saari, T. I., M. Uusi-Oukari, et al. (2011). "Enhancement of GABAergic activity: neuropharmacological effects of benzodiazepines and therapeutic use in anesthesiology." Pharmacol Rev 63(1): 243-267.

Saliba, R. S., K. Kretschmannova, et al. (2012). "Activity-dependent phosphorylation of GABA(A) receptors regulates receptor insertion and tonic current." Embo J 31(13): 2937-2951.

Saliba, R. S., G. Michels, et al. (2007). "Activity-dependent ubiquitination of GABA(A) receptors regulates their accumulation at synaptic sites." J Neurosci 27(48): 1334113351.

Smith, A. J., L. Alder, et al. (2001). "Effect of alpha subunit on allosteric modulation of ion channel function in stably expressed human recombinant gamma-aminobutyric acid(A) receptors determined using (36)Cl ion flux." Mol Pharmacol 59(5): 11081118.

Song, M. and R. O. Messing (2005). "Protein kinase C regulation of GABAA receptors." Cell Mol Life Sci 62(2): 119-127.

St-Pierre, M. V. and K. S. Pang (1995). "Concentration-dependent metabolism of diazepam in mouse liver." J Pharmacokinet Biopharm 23(3): 243-266.

Sun, M. K., W. Q. Zhao, et al. (2001). "Theta rhythm of hippocampal CA1 neuron activity: gating by GABAergic synaptic depolarization." J Neurophysiol 85(1): 269-279. 
Tietz, E. I., T. H. Chiu, et al. (1989). "Regional GABA/benzodiazepine receptor/chloride channel coupling after acute and chronic benzodiazepine treatment." Eur J Pharmacol 167(1): 57-65.

Tietz, E. I., X. J. Zeng, et al. (1999). "Antagonist-induced reversal of functional and structural measures of hippocampal benzodiazepine tolerance." J Pharmacol Exp Ther 291(3): 932-942.

Timofeev, I., F. Grenier, et al. (2002). "The role of chloride-dependent inhibition and the activity of fast-spiking neurons during cortical spike-wave electrographic seizures." Neurosci 114(4): 1115-1132.

Turkmen, S., T. Backstrom, et al. (2011). "Tolerance to allopregnanolone with focus on the GABA-A receptor." Br J Pharmacol 162(2): 311-327.

Unwin, N. (1989). "The structure of ion channels in membranes of excitable cells." Neuron 3(6): 665-676.

Uusi-Oukari, M. and E. R. Korpi (2010). "Regulation of $\operatorname{GABA}(A)$ receptor subunit expression by pharmacological agents." Pharmacol Rev 62(1): 97-135.

van Rijnsoever, C., M. Tauber, et al. (2004). "Requirement of alpha5-GABAA receptors for the development of tolerance to the sedative action of diazepam in mice." $\underline{J}$ Neurosci 24(30): 6785-6790.

Vinkers, C. H. and B. Olivier (2012). "Mechanisms Underlying Tolerance after Long-Term Benzodiazepine Use: A Future for Subtype-Selective GABA(A) Receptor Modulators?" Adv Pharmacol Sci 416864(10): 29.

Vinkers, C. H. and B. Olivier (2012). "Mechanisms Underlying Tolerance after Long-Term Benzodiazepine Use: A Future for Subtype-Selective GABA(A) Receptor Modulators?" Adv Pharmacol Sci 2012: 416864.

Vinkers, C. H., R. van Oorschot, et al. (2012). "GABA(A) Receptor alpha Subunits Differentially Contribute to Diazepam Tolerance after Chronic Treatment." $\underline{\text { PLoS }}$ One 7(8): e43054.

Wafford, K. A., P. J. Whiting, et al. (1993). "Differences in affinity and efficacy of benzodiazepine receptor ligands at recombinant gamma-aminobutyric acidA receptor subtypes." Mol Pharmacol 43(2): 240-244. 
Walter, H. J. and R. O. Messing (1999). "Regulation of neuronal voltage-gated calcium channels by ethanol." Neurochem Int 35(2): 95-101.

Whiting, P. J. (2003). "GABA-A receptor subtypes in the brain: a paradigm for CNS drug discovery?" Drug Discov Today 8(10): 445-450.

Wong, G., T. Lyon, et al. (1994). "Chronic exposure to benzodiazepine receptor ligands uncouples the gamma-aminobutyric acid type A receptor in WSS-1 cells." $\underline{\text { Mol }}$ Pharmacol 46(6): 1056-1062.

Wu, Y., H. C. Rosenberg, et al. (1994). "Subunit- and brain region-specific reduction of GABAA receptor subunit mRNAs during chronic treatment of rats with diazepam." J Mol Neurosci 5(2): 105-120.

Xiang, K., D. E. Earl, et al. (2008). "Chronic benzodiazepine administration potentiates high voltage-activated calcium currents in hippocampal CA1 neurons." J Pharmacol Exp Ther 327(3): 872-883.

Xiang, K. and E. I. Tietz (2008). "Chronic benzodiazepine-induced reduction in GABA(A) receptor-mediated synaptic currents in hippocampal CA1 pyramidal neurons prevented by prior nimodipine injection." Neurosci 157(1): 153-163. 